\title{
5 Temples, Poleis and Paramount Chiefs: The 'Archaic-Classical' period (c. 600/550-370 BC).
}

\section{I I N T R O D U C T I O N}

The period between approximately 600 and $350 \mathrm{BC}$ is often indicated as the Archaic- Classical period of southern Italy. As in many analogous cases, the chronological schemes and denominations of periods that classicists had primarily devised for central and southern Aegean areas have been transferred to other regions and districts. In archaeology they often have implicit connotations of style and values. From this point of view, however, there is little reason to apply such terms - let alone a combination of these - to southern Italy. If, for instance, the term 'classical' is supposed to indicate a period of great artistic, intellectual and economic flourishing (as, for instance, for 5th- and 4th-century Athens), it should be noted that substantial parts of the 5th and 4th centuries BC were certainly not a 'classical' period in that particular sense in many parts of southern Italy. The Golden Age of southern Italy in fact was the period between 370/350 and 270/250 BC (see chapter 6) with perhaps the 'Archaic' period between c. 570/550 and 470/450 as second best.

Similar observations can be made concerning the term 'archaic'. The 6th century BC was 'oldfashioned' (arkhaikós) only to 'post-archaic' Greeks who looked at the sculptures or the temples. As we shall see below, the period was crucial to the formation of a completely new southeast Italy that ranked among the most prosperous areas of the Mediterranean. If, however, terms like 'archaic' and 'classical' are exclusively taken as a convenient labels for a particular group of decades that are characterized by powerful new impulses, they can be retained. They will be used here in that particular sense only, without any connotations concerning the character of the period concerned. The use of a traditional term, however mistaken the label may be, has a distinct advantage over the introduction of a new, possibly more correct term. The term'Archaic-Classical' does not contribute to the already substantial confusion and haziness in the field of labeling and archaeological terminology.

In both the 6th and the later 4th centuries BC a series of stunning innovations took place that resulted in new physical, economic and social landscapes in southern Italy. These innovations lost much of their impetus in respectively the later 5th and later 3rd centuries BC. These moments of sudden and massive change, therefore, have been chosen here as the starting points of new episodes of this narrative on the 1st-millennium BC in southeast Italy.

\subsection{THE RISE OF URBAN CENTRES AND SA N T UARIES IN ThE COASTAL STRIP OF THE G ULF OF TARAN T O}

Sudden and drastic innovations characterize the start of the archaic-classical period in southern Italy. These are most vividly expressed in new forms of human occupation. Somewhere between 625 and 550 a completely new type of settlements made its appearance in southeast Italy. In the relatively short time of only 50 to 75 years, four strictly organized, highly complex settlements came into being. These settlements are conventionally indicated as 'Greek poleis' or 'Greek colonies' (fig. 5.1). The westernmost of these was Sybaris (later: Thourioi; Roman Copia) in northern Calabria. The others were Siris 


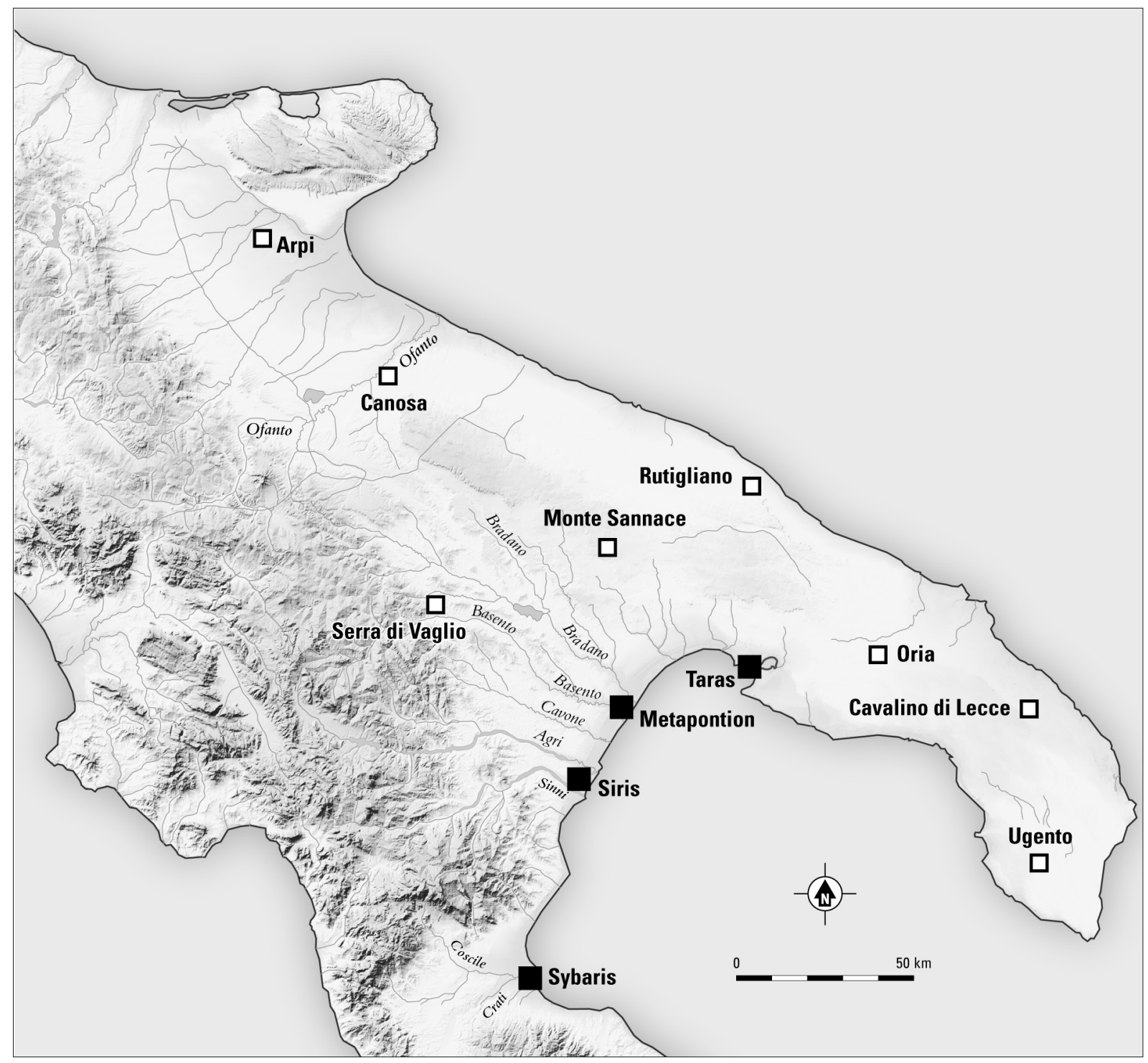

Fig. 5.1. Map showing the most important settlements discussed in this chapter; solid square: Greek poleis; open square: non-Greek central places.

(later: Herakleia/Heraclea; Byzantine/Italian: Policoro) and Metapontion (later: Roman Metapontum; Italian Metaponto) on the coast of the present-day region of Basilicata, and Taras (later: Roman Tarentum; Italian Táranto) in the southwestern tip of the region of Apulia. At least two of these (Siris and Metapontion) were built on top of small and dispersed settlement clusters of earlier times. ${ }^{1}$ They all came into being in the coastal strip of southeast Italy, i.e. in the area where contacts between Italic groups and Aegean Greeks had been particularly intense during much of the 7th century BC. They were, therefore, peripheral to indigenous inland polities.

The setting in which these four towns arose, displays a series of recurrent characteristics. They were not just near the coast, they were actually on the coast: each of these controlled a stretch of beach and a natural harbour (river mouth) that could accommodate ships. Three of them were new settlements

1 See chapter 4.3 above; for both Sybaris and Taras the evidence concerning the character of the settlement of the 7 th century is thin and inconclusive (cf. Yntema 2000). 


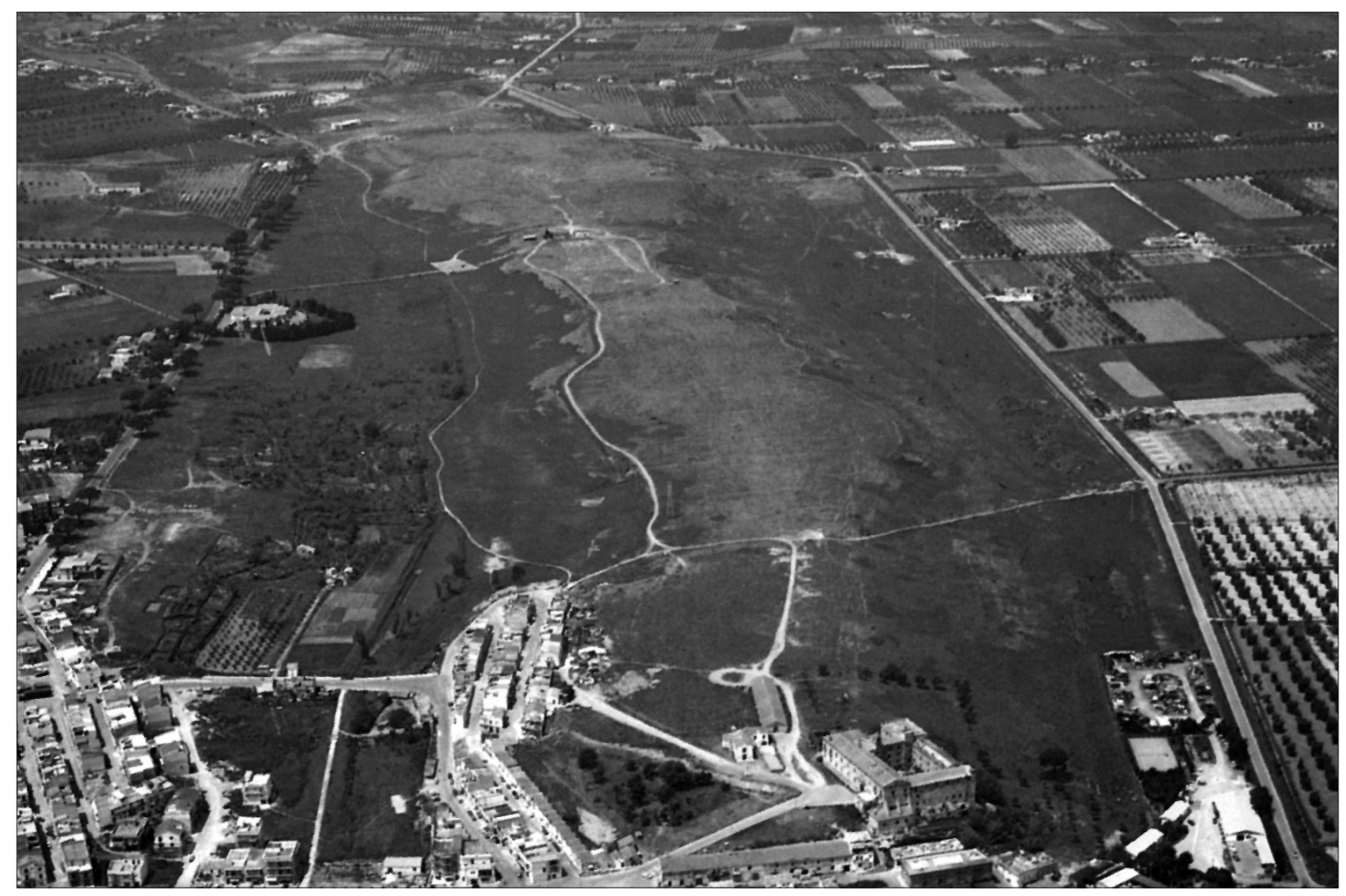

Fig. 5.2. The site of Siris/Herkleia from the air (1982). Courtesy Soprintendenza Basilicata.

at the mouth of important rivers that connected the coastal settlement to inland areas. Sybaris was situated on the rivers Coscile and Crati that came from the inlands of northern Calabria and Siris overlooked the mouths of the rivers Agri and Sinni that gave access to the inlands of western Basilicata (fig. 5.2). Metapontion arose in the flat area between the mouths of the Bradano and Basento whose river basins made up much of eastern Basilicata and the western part of present-day Apulia. The town of Taras was an exception to this rule. The settlement had a long history (Bronze Age origins) and developed on a lowly promontory between the Gulf of Taranto and a lagoon (now known as the Mar Piccolo) that - like the river mouths and beaches of Sybaris, Siris and Metapontion - provided excellent harbour facilities. In the Taras area, however, there were no substantial rivers that provided an easy access from the coastal strip to inland areas.

The four new settlements of urban type differed from earlier and from other contemporary settlements in the same part of Italy in several respects. Their most conspicuous physical characteristic is that each of them had a very regular layout (fig. 5.3 and fig. 6.2). These settlements consisted, moreover, of a concentrated cluster of buildings and roads and had an unprecedented density of habitation: more people lived on a square acre than ever before in southeast Italy. This new type of settlement contained public spaces, sacred areas, habitation quarters and burial plots. These features, moreover, were all clearly separated in spatial respect. The four settlements of Sybaris, Siris, Metapontion and Taras, therefore, had a decidedly urban character.

The state of research concerning these four sites differs substantially. Sybaris, reportedly destroyed by its neighbour Kroton in 510, lived on as the pan-Hellenic apoikía of Thourioi (since 444 BC) and the Roman colony of Copia (since 194 BC). The site was covered with tons of mud deposited by the riv- 


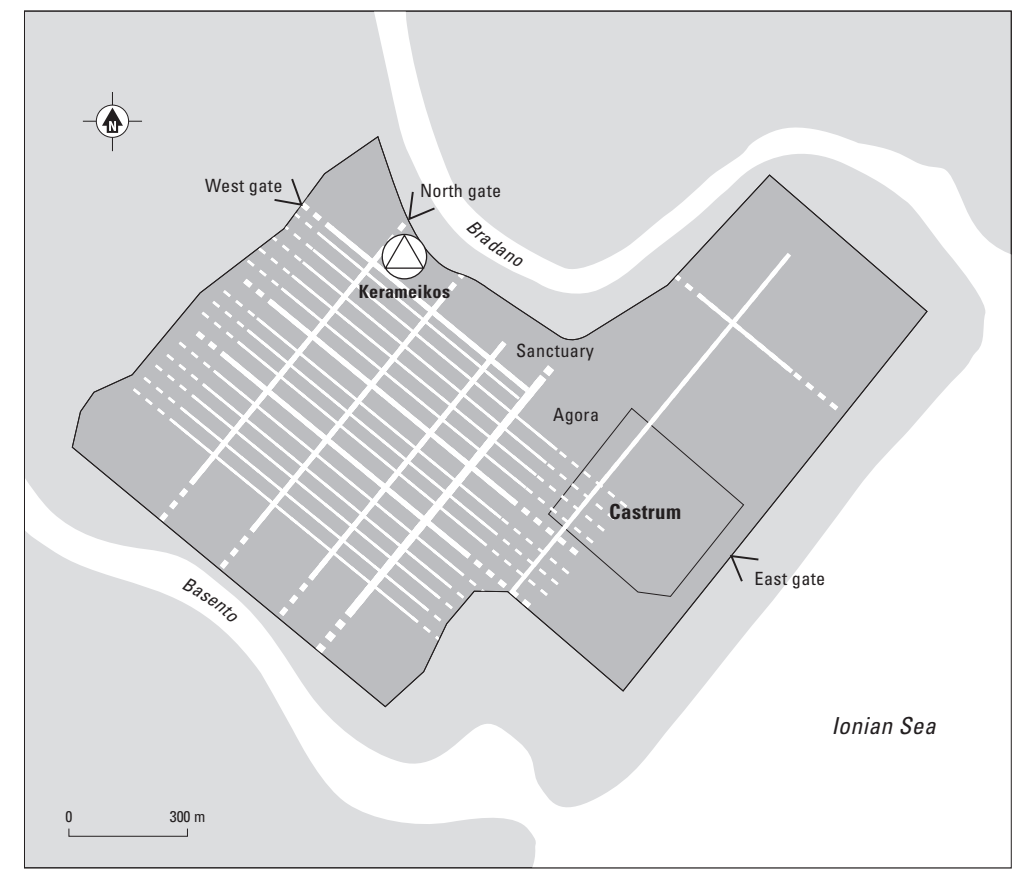

Fig. 5.3 Regular layout of the polis of Metapontion.

ers on which it was born. Only a limited part of the site has been investigated. ${ }^{2}$ Siris is believed to have eclipsed (though not completely) around $535 \mathrm{BC}$ and had its 6th- and early 5th-century phases recycled by Herakleia (from the 5th century BC till within Roman times). Since medieval and modern Policoro covers only a small part of the ancient settlement, there is a considerable quantity of information concerning the town. ${ }^{3}$ The main foci of attention in

these investigations have been the 7th century BC and the Hellenistic period. The remains of ancient Taras are more problematical. The town continued to exist to the present day and was completely built over. ${ }^{4}$ Although a large number of burials has been recovered here during the expansion of the town during the 19th and 20th century, ${ }^{5}$ little is known about the settlement area of ancient Taras which is covered by the old town (città vecchia) and the late 19th-century expansion (the 'Borgo Nuovo'). The 'old town' was intensely inhabited from antiquity to the present day.

Metapontion is the most completely and most intensely investigated settlement of these four and must play the main role here. ${ }^{6}$ This substantial Greek polis dwindled into a modest Roman town that was abandoned in late Roman times. There are reasons to believe that the town was a fairly 'normal', albeit relatively wealthy polis of southern Italy: comparable features can usually be encountered in at least one of the remaining three towns of southeast Italy and two other poleis of southern Italy outside the area under discussion.

The creation of these four towns was an incredible achievement. Whilst earlier forms of settlements on the same spot were probably dispersed, relatively small and had a fairly modest material culture (the architectural remains, in any case, are flimsy), the new settlements, structured in a completely differ-

2 There are five major reports on the excavations at Sybaris: Sibari I. Saggio di scavo al Parco del Cavallo, NSc Suppl. I-1969; Sibari II. Scavi al Parco del Cavallo e agli Stombi, NSc Suppl III-1970; Sibari III. Rapporto preliminare della campagna di scavo: Stombi, Casa Bianca, Parco del Cavallo, San Mauro, NSc Suppl I-1972; Sibari IV. Relazione preliminare della campagna di scavo: Stombi, Parco del Cavallo, Prolungamento Strada, Casa Bianca, NSc Suppl I-1974. Sibari V. Relazione preliminare delle campagne di scavo 1973. NSc Suppl III-1988/89.

3 Cf. the Austrian excavations (e.g. Neutsch 1967; Hän- sel 1973, Otto 1996), those of the Superintendency of Basilicata (e.g. Berlingò 1986 and 1993, Tagliente 1986a and 1998) and those of the Siena university (Pianu 1990).

$4 \quad$ See, for instance, Wuilleumier 1939; Cento Anni; De Juliis 2000; Lippolis 2002.

5 For these burials, see, e.g. Ori di Taranto, Cento Anni, Lippolis 1994a, Graepler 1997 and Hempel 2001.

6 For good and short syntheses on the polis of Metapontion, see Carter 1998a, 5-17, Carter 2006 and De Siena 2001; for another recent synthesis, see De Juliis 2001. 

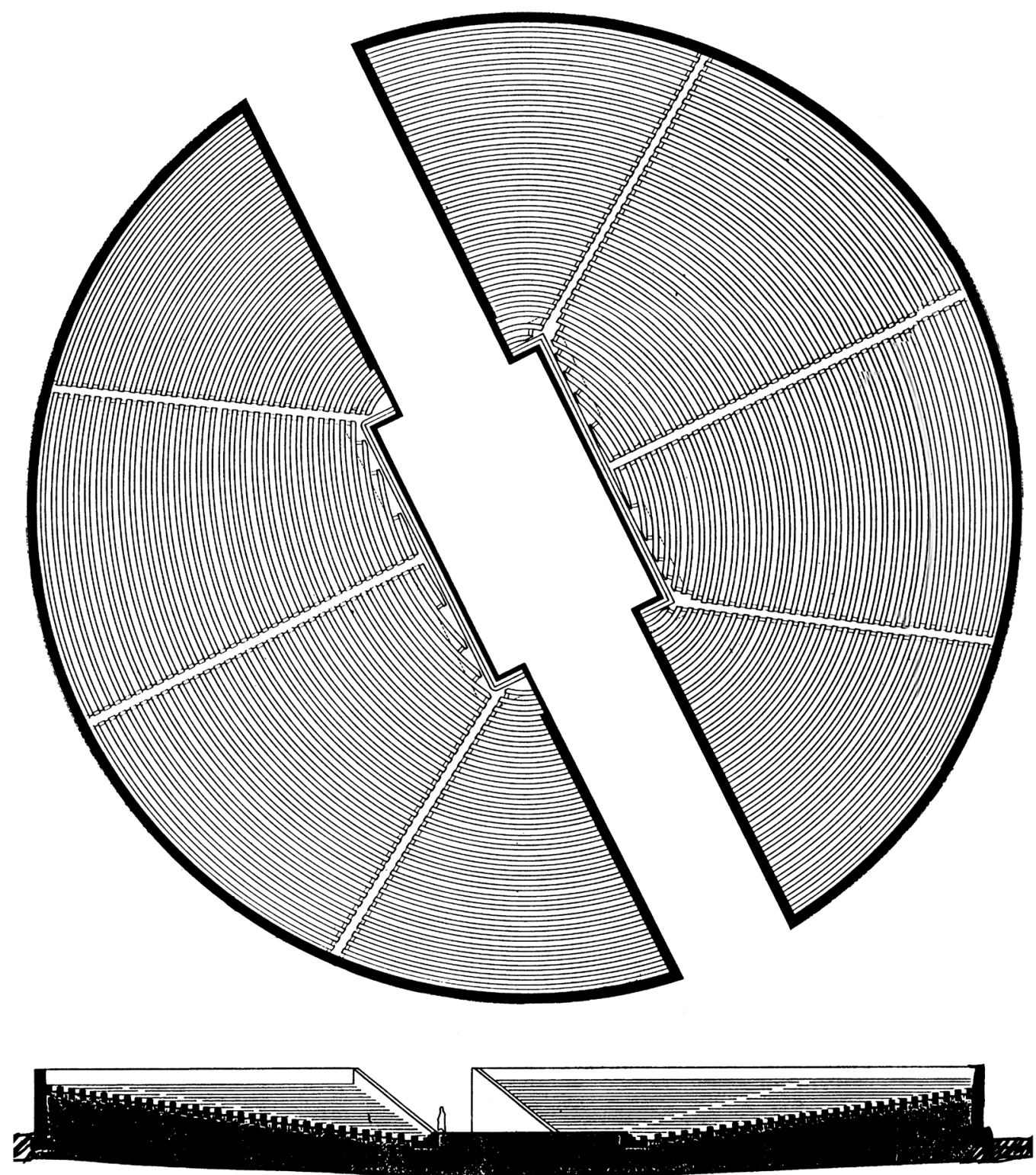

Fig. 5.4. Metapontion: reconstructed plan of the theatre-ekklesiasterion (5th century BC); courtesy Dieter Mertens, DAI.

ent way, were definitely more populous. They were also adorned with impressive buildings. Between the 2nd quarter of the 6th century and the 2nd quarter of the 5th century, for instance, the people of Metapontion built three large temples and several smaller religious buildings. These very labourintensive building activities took place, moreover, at a distance of at least $30 \mathrm{~km}$ from the quarries that contained the building materials required for such prestigious building projects (Mertens 1998, 124). Another impressive monument was built in the completely flat urban area of Metapontion during the 5th century which probably had a predecessor dating to the later 6th century: by making artificial slopes the Metapontines managed to create an amphitheatre-like construction that is mostly indicated as the theatre-ekklesiasterion. ${ }^{7}$ In its 5 th century phase it was large enough to accommodate c. 7.000 to 8.000 people (fig. 5.4).

Mertens / De Siena 1982, 16-22; Mertens / Greco

1996, 254. 
The layout of the new towns was invariably based on orthogonal schemes (fig. 5.3). The present data indicate that they have been devised during the first half to middle of the 6th century BC. At Metapontion there were two main roads (one northeast-southwest and one northwest-southeast) of some $20 \mathrm{~m}$ wide, a series of alleys (the so-called plateiai) of c. $12.00 \mathrm{~m}$ wide which alternated with relatively narrow $4.50 \mathrm{~m}$ wide streets (the so-called stenopoi). The towns usually had a kind of central square, the agora. Edifices such as ekklesiasteria (from the later 6th or century BC onward) and other less conspicuous public buildings were probably all in close proximity to the central square. ${ }^{8}$ The place of temples and sanctuaries within the settlement could vary considerably. Whilst there was a group of four temples close to the agora at Metapontion, there is no evidence that a comparable location for representative sacred buildings was also chosen in the remaining three poleis. At Taras (at least two major temples), the temples were located at the fringes of the settlement area. ${ }^{9}$

In addition to the clearly separated sacred and public spaces, these towns had special areas for houses, shops and workshops. These were all neatly arranged within the same orthogonal grid. The houses filled the insulae/strigae created by the grid of streets. The earliest dwellings of Metapontion did not make up one single cluster near the public area, but were somewhat dispersed over the town area. The orthogonal grid of the town was gradually filled in during the later 6th and 5th centuries BC. As for the place of shops and workshops, no information has been supplied hitherto. Since these were probably closely connected to households and clientele, they are likely to have been close to the Metapontine agora and situated on major thoroughfares of the town. Smelly, polluting and potentially dangerous activities were probably carried out at the periphery of the town. By the late 6th century kilns and workshops producing standardized pottery were operating at the north side of the town (fig. 5.3). They were close to the wall circuit and will be discussed in more detail in section 4.5 ("Changes in craft'). The outline of the settlement area of Metapontion was initially defined by earthworks (the so-called agger) that enclosed an enormous area of approximately 140 to 150 hectares. ${ }^{10}$ This agger consisted of stones and earth. ${ }^{11}$

Whilst the arrangement of the town of the living changed completely, the necropoleis continued to occupy approximately the same spot as in the 7th century BC. At Siris the Greek style burial grounds of Madonelle and Schirone (see chapter 4) continued to be in use during the 6th and early 5 th centuries $\mathrm{BC}$. The quantity of Siris burials during this period was invariably much larger than over any period of equal length of the 7th century BC. This suggests that more people died and that the population residing here augmented very substantially. A very similar observation can be made for the settlement of Taras. Here the 6th century necropolis - clearly separated from habitation areas and sacred areas - is characterized by an increasingly large quantity of tombs and more strictly organized burial plots. ${ }^{12}$ For Metapontum comparable observations can be made. Here new, large and coherent burial plots made their appearance towards the end of the 7th century BC. Again they were clearly separated from the habitation areas. The largest clusters of tombs were north of the town. ${ }^{13}$

8 There is evidence from Metapontion, Neapolis and Posidonia for iuxtaposition of agora and ekklesiasterion. The circular Metapontion ekklesiasterion had a diameter of $62 \mathrm{~m}$ (Mertens / De Siena 1982).

9 The temple underneath the church of San Domenico is at the western fringes of the settlement, the columns of the second temple can still be seen near the Castello Aragonese (the eastern fringes of the settlement area of archaic times).

10 This large area was not completely filled in during the 6th century BC (see Mertens 1998, 126). All the burial grounds, however, were invariably outside the area surrounded by the agger.

11 De Siena 1998, 141-143.

12 Neeft 1994.

13 For the location of the town's burial plots, see Carter 1998a; De Juliis 2001, 117-128. These are the large burial plots usually indicated as 'La Crucinia' and 'Casa Ricotta'; for an exhaustive bibliography on Metapontion's burial grounds, see De Juliis 2001, 117, note 1. 


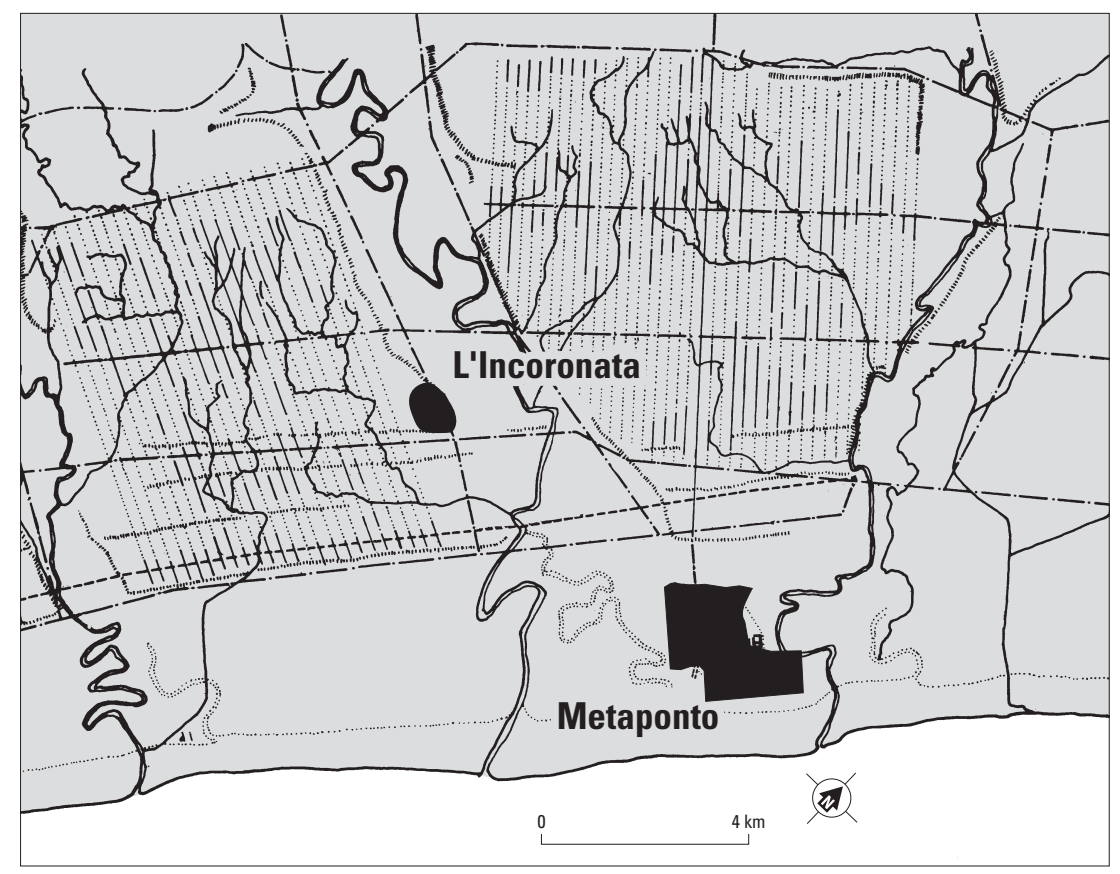

Fig. 5.5. Metapontion. Chõra with regular subdivision of territory. After Adamestianu 1974.

We have seen in the chapter on the Iron Age that 7th-century dispersed Siris displayed a mix of cremation and inhumation. With the coming of the new urban centres of 6th-century inhumation became the only burial custom. In the Archaic-Classical period the deceased, both in urban and rural necropoleis of the urban centres, were usually buried outstretched on their back in graves of various types. These ranged from simple pit graves dug in the earth to fairly large cist tombs consisting of large blocks of sandstone or limestone. ${ }^{14}$

Both the new and strict organization of space and the erection of impressive buildings in the four new towns of southeast Italy suggest the presence of a strong central authority. Such labour-intensive actions require far-reaching decisions and sound planning. Because the decision altered the existing situation drastically by creating an urban settlement with a regular layout, it must have had a wide support. It required, moreover, a very substantial input of a very substantial working force. Obviously, the new towns of the 6th century BC managed to create unprecedented surpluses and were able to organize a manpower that was large enough to enter upon time-consuming activities such as the construction of temples, public buildings and fortifications. The data seems to suggest that it was not just the introduction of a new kind of settlement with decidedly urban features that characterizes the 6th century BC, but they also indicate that this new phenomenon was in some way connected with entirely new forms of socio-political organization in southeast Italy. They did not just have the physical traits of an urban centre, they were in fact truly urban societies. These new settlements were definitely states in which family ties continued to be important, but these were no longer dominant in the political arenas of the four new towns. In the 6th century BC, Sybaris, Siris, Metapontion and Taras were poleis not just in the physical, but also in the socio-political sense of the word.

The birth of urban centres was an important change in the settlement patterns of southeast Italy. It was, however, not the only change in this field. The creation of these towns went hand in hand with the creation of an intensely cultivated and intensely inhabited countryside that was closely connected to these urban centres. The first traces of this phenomenon were discovered on aerial photographs of the Metapontion area in the $1960 \mathrm{~s} .{ }^{15}$ Soon a follow-up was made by means of ground reconnaissance. ${ }^{16}$

14 A synopsis of burial forms at Metapontion is found in De Juliis 2001, 120-121; for a synopsis on the burials of Taranto, see De Juliis 2000.
15 Schmiedt 1970.

16 Chevallier 1971; Adamesteanu / Vatin 1976. 


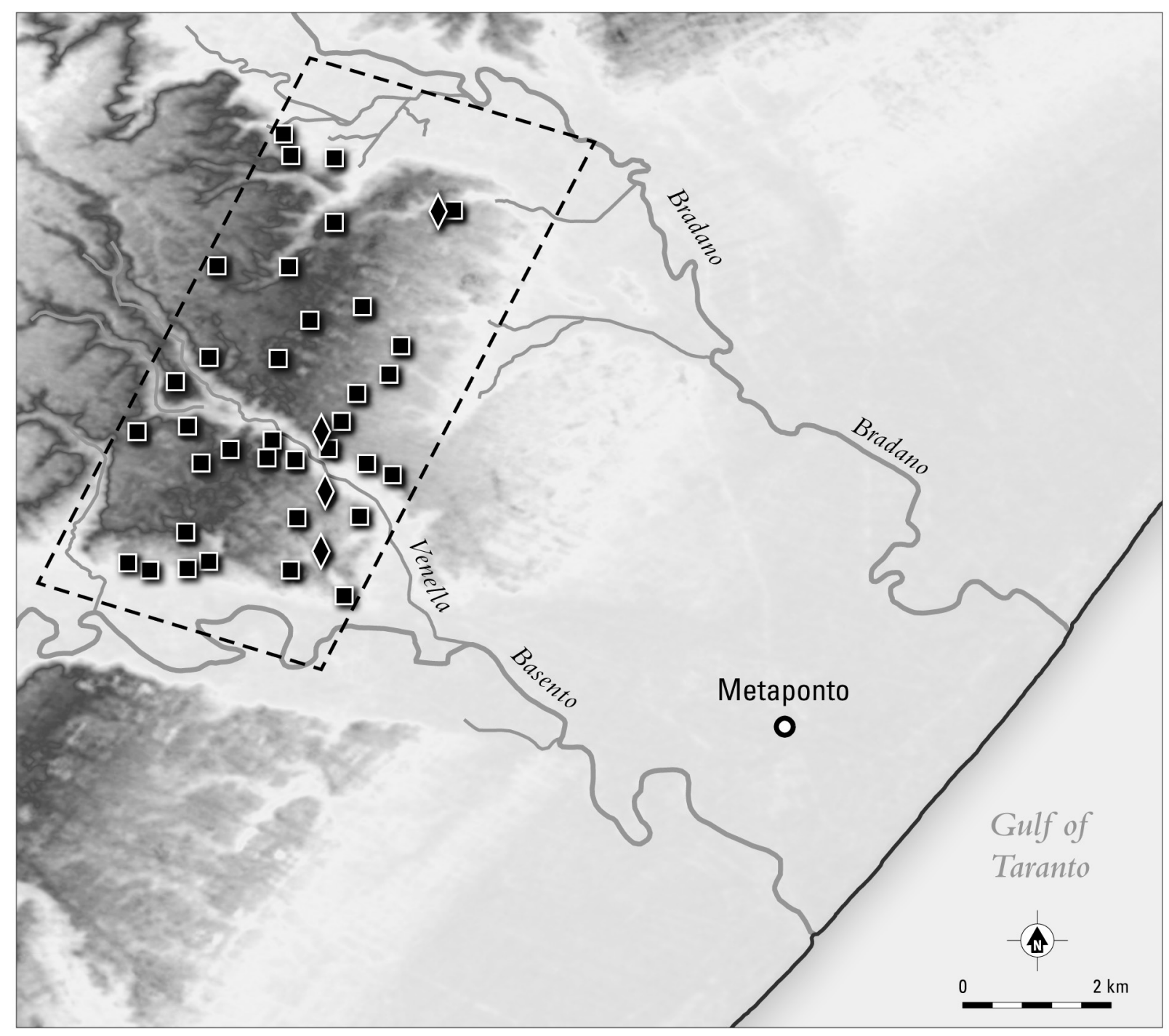

Fig. 5.6. Metapontion territory: distribution of rural sites, c. 500 BC (after Carter and Prieto 2011).

These activities led to the discovery of an orthogonal grid. It appeared to be the framework within which hundreds of regular agricultural plots and numerous farmsteads were situated (fig. 5.6). Checkup excavations demonstrated that the creation of a strictly organized countryside with orthogonal patterns could be dated to the early 5 th century BC. ${ }^{17}$ Not just the settlement area of Metapontion was spatially reorganized in a way that differed completely from that of the preceding period, but some two generations after the birth of the orthogonal town the same orthogonal grid was also extended over the rural area: preexisting patterns of both habitation and landholding were radically wiped out and an entirely new, systematically designed urban landscape (early to mid 6th century) and an entirely new, systematically designed rural landscape (early 5th century) were laid out.

The agrarian activities in the rural area close to Metapontion, however, started well before the creation of regular land divisions by means of a grid. From the end of the 1970s the rural area near Meta-

17 Carter 1996 and 2006. 


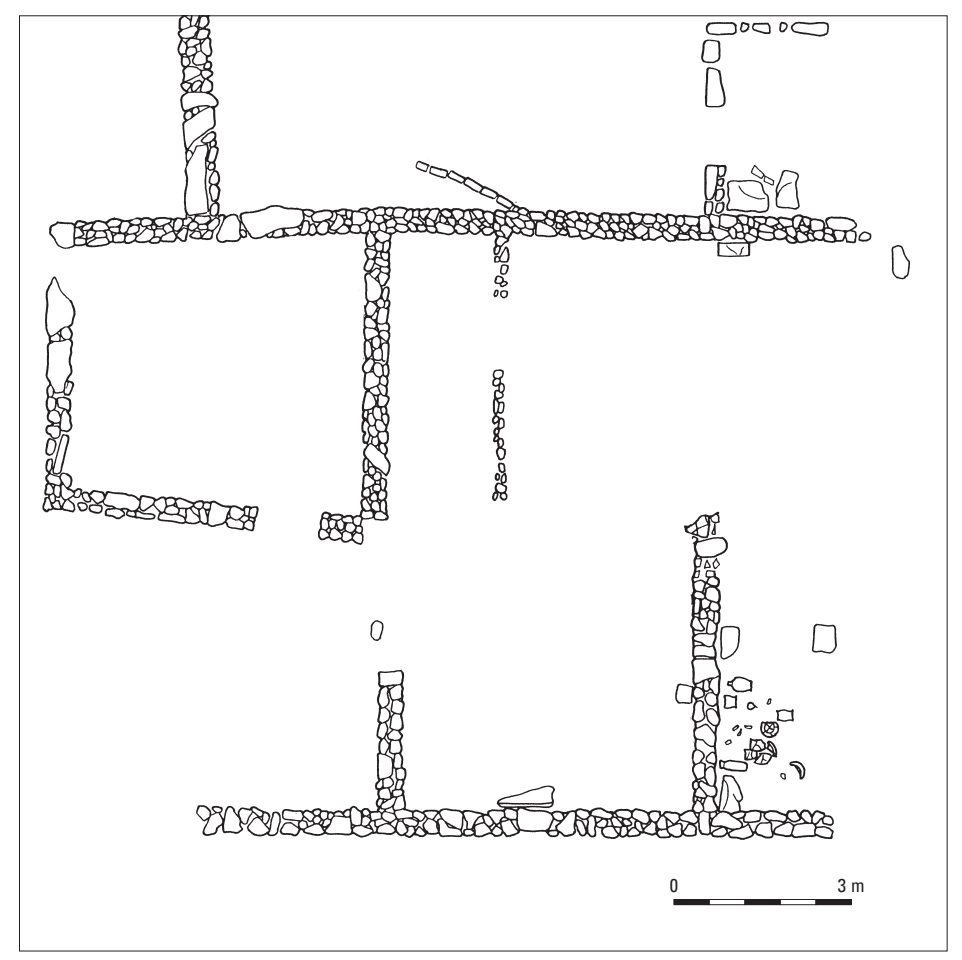

Fig. 5.7. Metapontion territory: Groundplan of a 6th-century farmstead at the site of Cugno del Pero (after Yntema 1993a).

pontion was subject to large-scale, fairly intensive and systematic field surveys. ${ }^{18}$ The results of the field surveys indicate that the first farmsteads were established in the Metapontion countryside some 50 years before the birth of the rural grid. In a large transect between c. 6 and $10 \mathrm{~km}$ from the town dozens of 6th-century farm sites were discovered (fig. 5.6). The farms of this earliest generation, therefore, were not always invariably close to the town. They suggest that the territory of the urban centre of Metapontion, by about the middle of the 6th century BC, was vast and covered at least an area of some 125-150 $\mathrm{km}^{2}$ between the rivers Bradano and Basento.

Some of the farmsteads that were identified during the field surveys were sufficiently well-preserved to allow excavation. They were relatively simple and consisted of a few adjoining rooms and a courtyard only (fig. 5.7). These farms are believed to have been inhabited by one-family units. ${ }^{19}$

This rigidly organized landscape of cultivated fields with farmsteads was the territory of the urban settlement. The Greeks themselves called it the chōra, the area that was economically, socially and politically so closely linked with the urban centre that town and countryside together made up the socio-political unit of the polis, the city state. In this chorra, necropoleis and sanctuaries were present. The rural necropoleis were mostly small and contained a limited amount of burials. They were strewn all over the countryside and can usually be related to a dispersed group of nearby farmsteads. The earliest burials in this rural area even precede the farms and date to earlier 6th century BC. ${ }^{20}$ It is attractive to see these as the graves of the first generation of pioneer farmers that reclaimed new areas in the territory of Metapontion. Surprisingly both the grave rituals and physical anthropology suggest that these earliest 'Greek' farmers have partly indigenous roots. ${ }^{21}$

One of the larger and more intensely studied burial plots of Metapontion is the rural, so-called Pantanello necropolis some $4 \mathrm{~km}$ north of the town. ${ }^{22}$ The burials started here before the middle of the 6th

18 Carter 1981 and 2006; D’Annibale 1983; Carter / Prieto 2011.

19 Carter 1996.

20 Carter 1998a, 7.

21 The burials customs in these early 6th-century graves (persons in contracted position) are very similar to those found in non-Greek areas of southeast Italy and differ from the burial customs in the 'urban' and the more recent rural graves of the Metapontion area. See
Carter 1998a, 168 ('Contracted burials’). Research into the skeletal remains of rural necropoleis, moreover, confirms that the bones of the Metapontion farmers display a much closer affinity with those of indigenous populations than with those of Greek populations (W. Smith, MA thesis, VU University Amsterdam, 2005).

22 The Pantanello necropolis is published in Carter 1998a. 


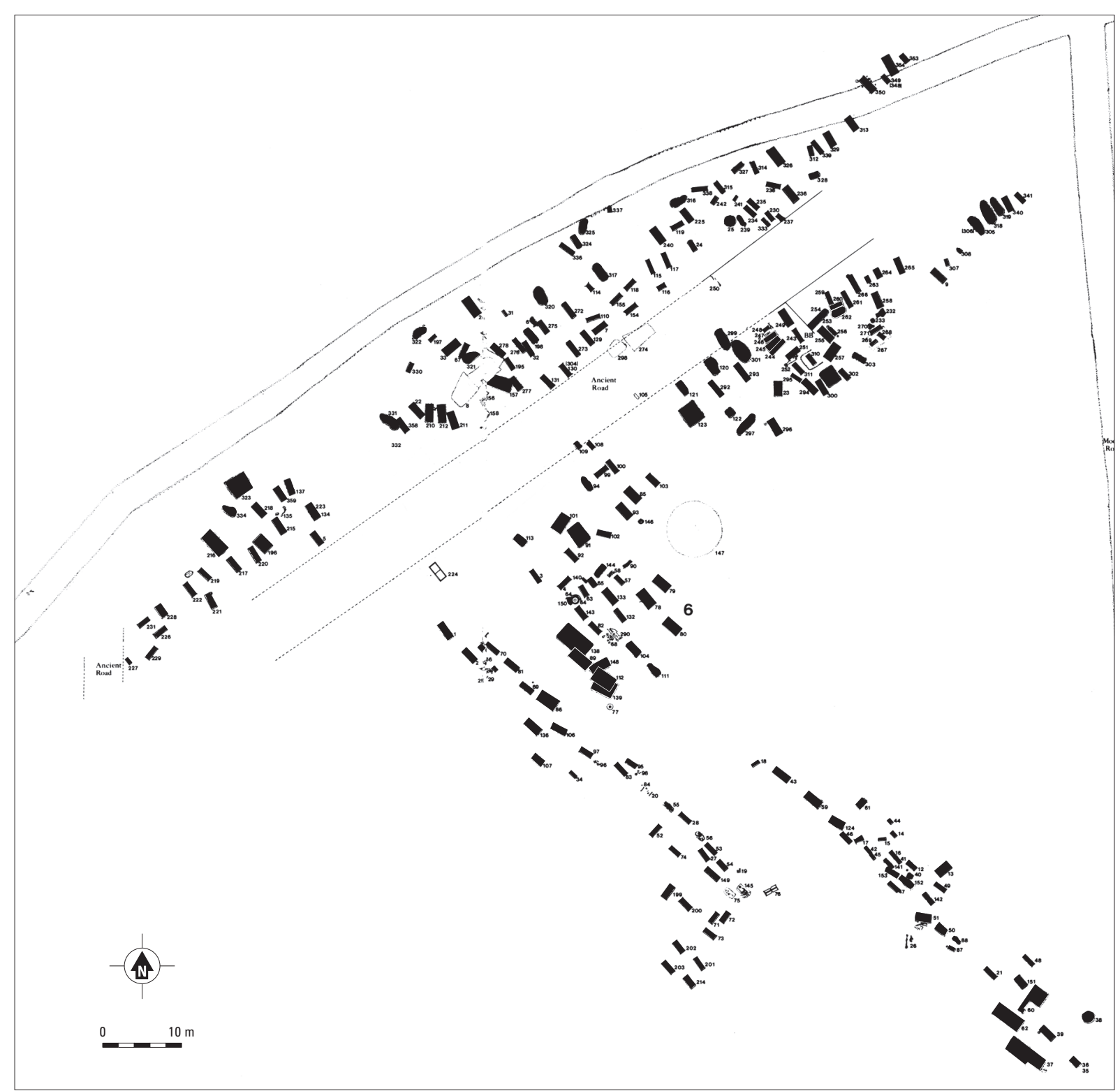

Fig. 5.8. Metapontion territory. The rural necropolis of Pizzica Pantanello, 6th-3rd century BC; after Carter 1998.

century BC and continued into the 3rd century BC (fig. 5.8). The Pantanello necropolis, situated near the crossing of two important country roads, is believed to have been the communal burial ground of approximately a dozen of isolated farmsteads that were in close proximity of these crossroads.

The one-family farmsteads were not the earliest features in the area surrounding the urban centre of Metapontion. The first rural sanctuaries made their appearance some 30 to 50 years earlier. ${ }^{23}$ The most informative report concerns the sanctuary of Artemis and Zeus at the site of San Biagio alla Venella, some $6 \mathrm{~km}$ west of Metapontion which contained a richly decorated sacellum as early as the beginnings of the 6th century BC (fig. 5.9). ${ }^{24}$ Most of these rural sacred places are in close proximity of wells. They are usually interpreted as signs that the inhabitants of the urban centre by establishing 


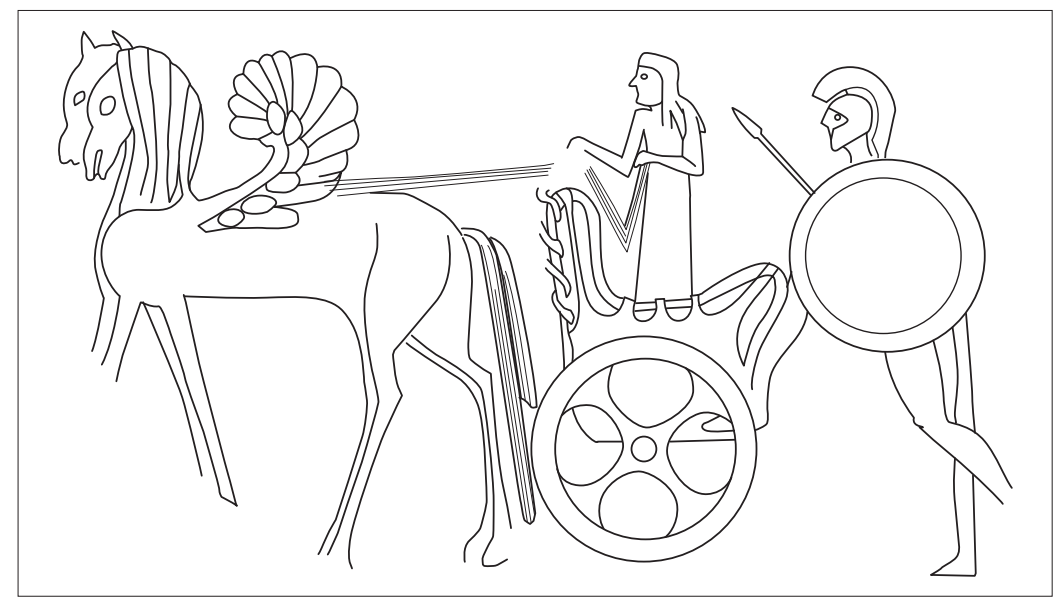

Fig. 5.9. Metapontion territory.

Terracotta plaque from the sanctuary of San Biagio alla Venella; early 6th century BC. Drawing Bert Brouwenstijn, ACVU.

the sanctuary laid a claim on the soil or marked the frontier of their new territory. ${ }^{25}$ This hypothesis seems to be confirmed by the position of these rural sanctuaries. They are mostly several kilometers from the town. But since the pre-Greek indigenous populations had no sacred places that leave traces in the archaeological record, these 'new and Greek' rural sanctuaries at a considerable distance from the town centre could, in principle, also be sacred places with a venerated 'indigenous' history: they are only recognizable to us from the very moment that votive offerings were deposited according to originally Greek customs (be it by either Metapontines or natives or by both groups). Traces of preGreek presence underneath the San Biagio sanctuary strongly suggest that this possibility should not be excluded. ${ }^{26}$ The rural sanctuaries near the margins of Greek territories are also believed to been places to demonstrate ritualized competition ${ }^{27}$ and may have been free havens where contacts between people belonging to two different groups or polities were made and where transactions between them took place under the protection of the god. In this view these sanctuaries can also be seen as the thresholds between different worlds: between those of the gods and those of men and between the world of the Metapontines and the world of the Others. The Hera sanctuary currently known as the 'Tavole Palatine', had the most impressive outfit of these extra-urban sanctuaries: a large limestone temple of the late 6th century that dominated the valley of the lower Bradano river (fig. 5.10).

Much of what has been said above is based on information coming from only one of these four coastal sites: Metapontion. One might well ask whether this settlement is actually a good representative and whether more or less comparable developments took place in Sybaris, Siris and Taras. It must be admitted that Metapontion might have been a relatively wealthy polis of southern Italy. There are both literary and archaeological indications that a local tyrant named Archelaos may have been responsible for a construction boom in about 550/530 BC. ${ }^{28}$ Ancient written sources however, suggest that Sybaris - not Metapontion - was the most opulent of these four towns. Features comparable to those of Metapontion can also be encountered at Sybaris, Siris and Taras. The three remaining towns all had a regular layout. Siris had at least one and Taras at least two major temples; Taras's countryside can be shown to have been littered with rural settlements and rural necropoleis as early as the late 6th century BC $^{29}$ and 6th-century 'frontier' sanctuaries are also reported from the Taras area and the Sybaris district. ${ }^{30}$

25 De Polignac 1984; Carter 1994 and 1996; Leone 1998.

26 On this subject, see Carter 1978; Lomas 1993, 130. Traces of pre-Greek cult activities underneath a to all appearances Greek sanctuary were also found at the site of Timpone della Motta, Francavilla (Calabria); see Kleibrink 2006, Attema et al. 2010, 95-98.
27 De Polignac 1995, 37.

28 Carter 1998a, 8.

29 Cocchiaro 1981; Alessio / Guzzo 1989/90.

30 'Frontier' sanctuaries have also been reported for Taras (Roccaforzata) and Sybaris (Timpone della Motta, San Mauro and Cozzo Michelicchio). 
Another well-researched settlement of the same type is Posidonia/Paestum which is definitely outside the area discussed here. This urban settlement has many features in common with Metapontion. ${ }^{31}$ One must, therefore, conclude that Metapontion was probably a relatively opulent polis. But the new features displayed by that settlement during the 6th and early 5 th centuries BC were probably all shared by the three remaining towns of southeast Italy. They were urban centres characterized by a regular layout and the presence of public and sacred buildings; they were, moreover, surrounded by an inhabited, intensely cultivated rural area and had rural sanctuaries both in and at the periphery of their territories.

Summarizing the various new aspects discussed above, we can observe that the sequence of the developments in the four towns in statu nascendi was approximately as follows. In the preceding chapter we have seen that the first signs of change occurred in the final decades of the 7th and early 6th centuries. These signs came from both Taras and Metapontion. The former supplies evidence for increasingly large and increasingly coherent burial plots for the period under discussion. ${ }^{32}$ At Metapontion a sacred building (the so-called sacellum C) and a wooden structure was erected. The latter feature has been interpreted as an early form of public gathering place, since it was found underneath the 6th-century ekklesiasterion. At about the same time the settlement area was delimited by the construction of a large wall of earth and stones, usually refered to as 'the agger' ${ }^{33}$ Such public projects could only be carried out by a substantial community, of which the members closely cooperated and worked under the guidance of a central authority. These features, therefore, underline that the groups that lived on the spot, began to increase in size, began to display a rapidly growing degree of coherence (cf. both the settlement area and the burial plots) and began to have a centralized form of government.

The next step taken by such groups concerned the sacred world outside the settlement. Sites that have been recognized as Greek-style sanctuaries appeared at a considerable distance (some 8 to $10 \mathrm{~km}$ ) from the incipient urban centre. Whether the grip they exerted in this manner, was predominantly territorial and socio-political (i.e. sanctuaries stressing territorial claims) or purely mental (i.e. sanctuaries mediating contacts with the Otherworld, be it either that of the gods or that of those who were perceived as non-Greeks, or perhaps both) is still very much open to debate. This happened in the first decades of the 6th century BC. ${ }^{34}$ The foundation of these rural sanctuaries was soon followed by the construction of a more impressive outfit of the urban sanctuaries: the first series of large temples. Remains of these have been found at Siris (at least one major temple), Metapontion (three large temples) and Taras (at least two large temples).

The construction of the earliest specimens of these large temples started shortly before or around the middle of the 6th century BC. At a slightly later moment (540-520 BC) the first series of rural farmsteads made its appearance in the countryside (e.g. at Metapontion and Taras). In their wake came the highly systematic land division of Metapontion and the construction of the Metapontion ekklesiasterion. By the late 6th century BC, Sybaris, Metapontion and Taras ${ }^{35}$ were full-grown poleis and independent states that expressed their status, political independence, local identities and internal coherence by means of impressive buildings such as temples, city walls and a well-organized and densely inhabited countryside with villages, farmsteads and rural sanctuaries. The issuing of silver coins that carried the symbol of the new polity is another phenomenon that clearly gives the same messages. ${ }^{36}$ The earliest coins made their appearance around $530 \mathrm{BC},{ }^{37}$ i.e., before most of the poleis of mainland Greece did the same. They contained the symbols of the poleis: Sybaris had its bull, Metapontion its ears of corn and Taras its eponymous hero riding a dolphin (fig. 5.11).

\footnotetext{
1 Mertens 1998, 136.

32 Neeft 1994.

33 De Siena 1998, 141.

34 Carter 1994.
}

35 'Íonian'Siris is reported to have been conquered by its Achaean neighbours (see 4.7: Ancient written sources).

36 Papadopoulos 2002.

37 Stazio 1987. 

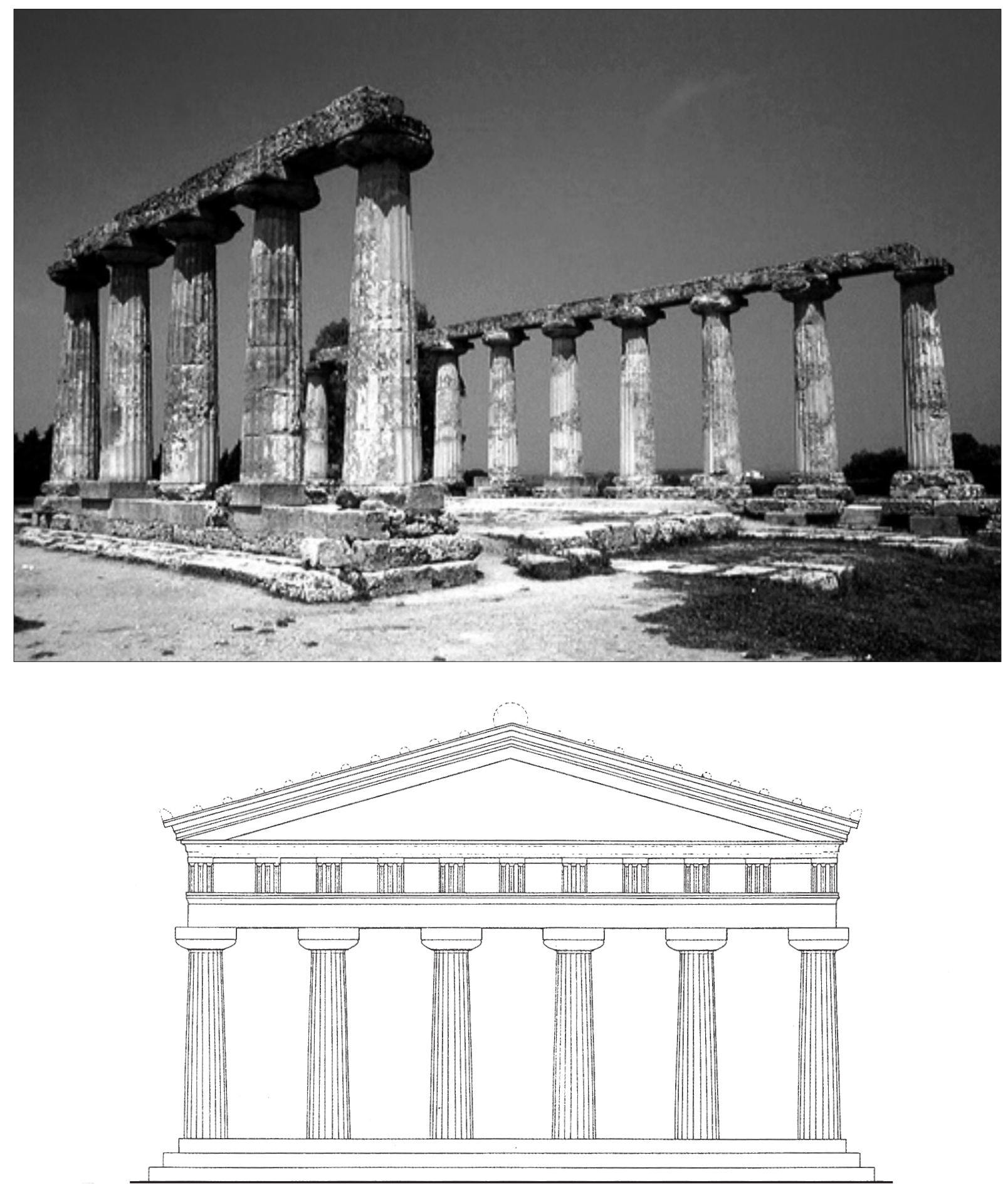

Fig.5.10. Metapontion, remains and reconstruction of the extra-urban temple currently known as the Tavole Palatine (archive ACVU and courtesy Dieter Mertens, DAI). 

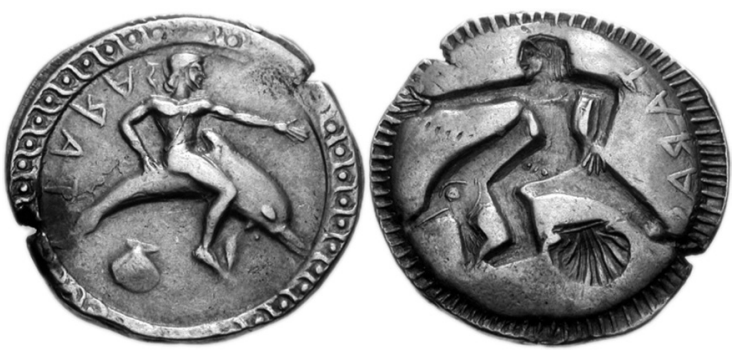

Fig. 5.11. Early silver stater from Taras (late 6th century BC). Courtesy Soprintendenza Taranto.

$620 / 600-600 / 570$ BC

larger, more coherent burial plots

first religious and public building activities (sacellum C, ikria of Metapontion) delimitation of the settlement area by means of an agger

$600 / 570-550 / 540$ BC

first rural sanctuaries (e.g. San Biagio alla Venella)

first activities leading to the construction of large temples of stone strict organization of settlement area

$550 / 540-500 / 490$ BC

completion of three large temples of stone and terracotta

first rural farmsteads

strict organization of rural area

Table 5.1. Timetable of the stages of rapid the developments at Archaic Metapontion (based on Carter 2006).

The creation of this strictly organized space must have altered the landscape in a very decisive way. Practically ex nihilo a completely new urban and new rural landscape were created in the Metapontion area. Similar features can be surmised to have come into being in the territories of the remaining towns. In the area between Sybaris and Taras large stretches of the wild coastal or sub-coastal landscape were turned into human artifacts. ${ }^{38}$ Though some of the now rural terrains may already have been tilled in the 7th or early 6th centuries, large portions of uncultivated areas must have been reclaimed. While for the 7th century BC we have constructed a picture of dispersed settlement with fields probably between and around the various settlement nuclei, the landscape that came into being in the 6th century BC shows vastly different features. The rigorous concentration of dwellings and the addition of substantial public and religious buildings resulted in a relatively densely packed urban centre. ${ }^{39}$ The new organization of the settlement area itself showed a marked separation between public, private and religious spaces. There was also a strict and unprecedented separation between urban and rural space. The town's defences were actually the physical demarcation line between both areas: they separated the town from its countryside. This separation, however, was not strict in the social sense: a large percentage of the town dwellers are likely to have been farmers having their fields outside the agger.

There was, moreover, extensive reclamation of large uncultivated areas in order to create the wellorganized countryside. At Metapontion, this was framed into the grand scheme of the orthogonal land division of the whole area. It should also be noted that in order to make these allotments the central authorities must actually have exerted political and military control over these areas. They probably considered them to be to the territories of their towns.

The implementation of such drastic measures required a substantial working force. The orthogonal layout with its urban roads and country lanes was the backbone of the innovation. It had to be measured out and constructed. Wooded areas had to be cleared in order to make them fit for agricultural

38 Osanna 1992.

39 In this respect our view is often biased by the images we have of 4th - and 3rd-century urban landscapes of the Greek world. The archaic Greek settlement was probably much less densely packed than we imagine, but it was undoubtedly a more coherent, definitely urban form of settlement than the settlement layouts that can be reconstructed for the 7 th century BC. 
purposes. Moreover, sacred, public and private buildings in the town had to be built. The same holds good for the farmsteads that littered the countryside. Although orthogonal Metapontion with its large temples and well-organized countryside was certainly not made in a handful decades (but the grand scheme behind these actions certainly was), the creation of both a substantial town and a large rural zone dedicated to agricultural activities was very labour-intensive indeed. It required the mustering of a quantity of manpower that went far beyond the possibilities of the probably few hundreds of inhabitants that populated the dispersed settlements of the coastal area of southeast Italy during much of the 7 th century BC. The appearance of these first urban agglomerates of southeast Italy, therefore, denotes the genesis of complex urbanized societies with a sophisticated political organization.

The birth of these four territorial farmer states altered the settlement pattern in the coastal area of the Gulf of Taranto completely. In the 7th century there were mainly larger and smaller clusters of fairly dispersed settlement nuclei. By about the middle of the 6th century BC there was a very clear settlement hierarchy in the same area. It was dominated by the urban centre having a territory that contained some villages/hamlets and a substantial quantity of isolated farmsteads, all depending on the urban centre.

\subsection{SETTLEMENT AN D RELIGION IN AREAS WITH NON- GREEK P O P U L A T I O N}

The drastic changes described above occurred in the narrow coastal strip between Sybaris and Taras. This was certainly not the only area of southeast Italy where major changes can be observed in the period under discussion. Tendencies towards urbanization or, in any case, increasing complexity in settlement forms can also be encountered in other parts of the area. It has been observed above that the extension of the dispersed settlements of the 8th century BC increased very substantially in the 7th century BC and could sometimes cover an area of well over 100 ha (e.g. the sites of Oria and Santa Maria d'Anglona, see chapter 4.2). By about the middle to later 6th century BC some of these settlements contracted: they lost much of their dispersed character by acquiring a more town-like appearance.

The most outspoken exponents of this urbanizing trend in areas outside the coastal strip of the Gulf of Taranto are the settlements of Cavallino di Lecce and Serra di Vaglio. The former is situated in an almost flat area in the very heart of the Salento peninsula (fig. 5.1), whilst Serra di Vaglio occupies a flat-topped mountain (c. $1025 \mathrm{~m}$ high) in the uplands of Basilicata (fig. 5.1). Each of these is likely to have had a special position in the settlement hierarchy of its district. Both sites originated as hut settlements in the Iron Age without showing any sign of having held a special position in that particular period. Cavallino was almost completely abandoned in the course of the 5th century BC, whilst Serra di Vaglio continued to exist to within the Hellenistic period.

Cavallino, now at the outskirts of the present-day provincial capital of Lecce, is subject to large-scale excavations from 1964 onwards with some intervals. ${ }^{40}$ It appears to have changed from a dispersed hut settlement into a more or less urban settlement from about the second quarter to middle of the 6th century BC onward. Its character, however, differed substantially from that of the four new towns on the Gulf of Taranto. The 6th-/early 5th-century settlement of Cavallino consisted of a central, open area from which roads departed in various directions (fig. 5.12). These roads were flanked by sidewalks and had drains. ${ }^{41}$ The wedges between these radial roads were only partly occupied by clusters of houses.

40 See, for instance, D’Andria 1977, 1979, 1982, 1996 and

$41 \quad$ Yntema 1982b, D’Andria 2005.

2005; Pancrazzi 1979. 

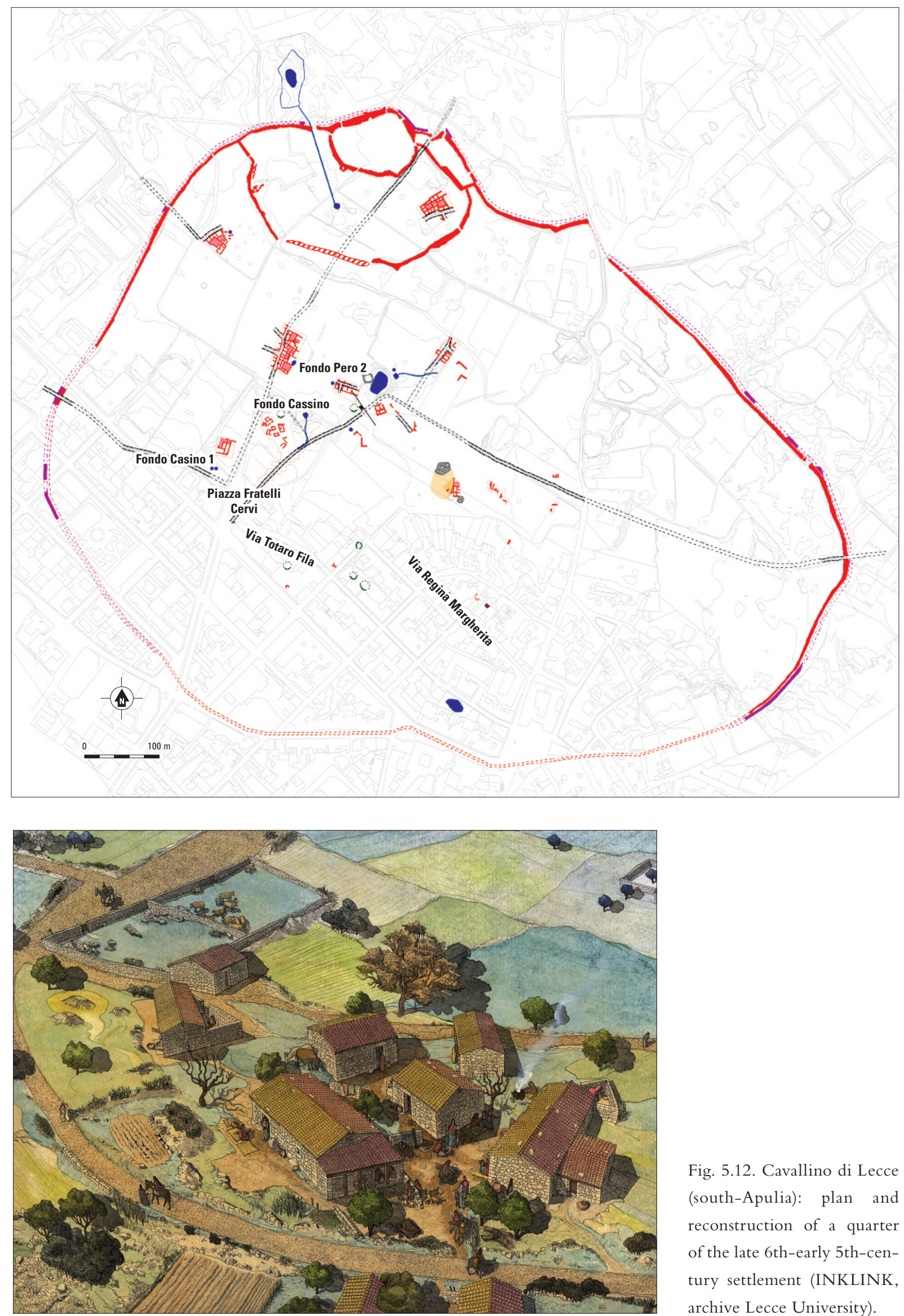

Fig. 5.12. Cavallino di Lecce (south-Apulia): plan and reconstruction of a quarter of the late 6th-early 5th-century settlement (INKLINK, archive Lecce University). 


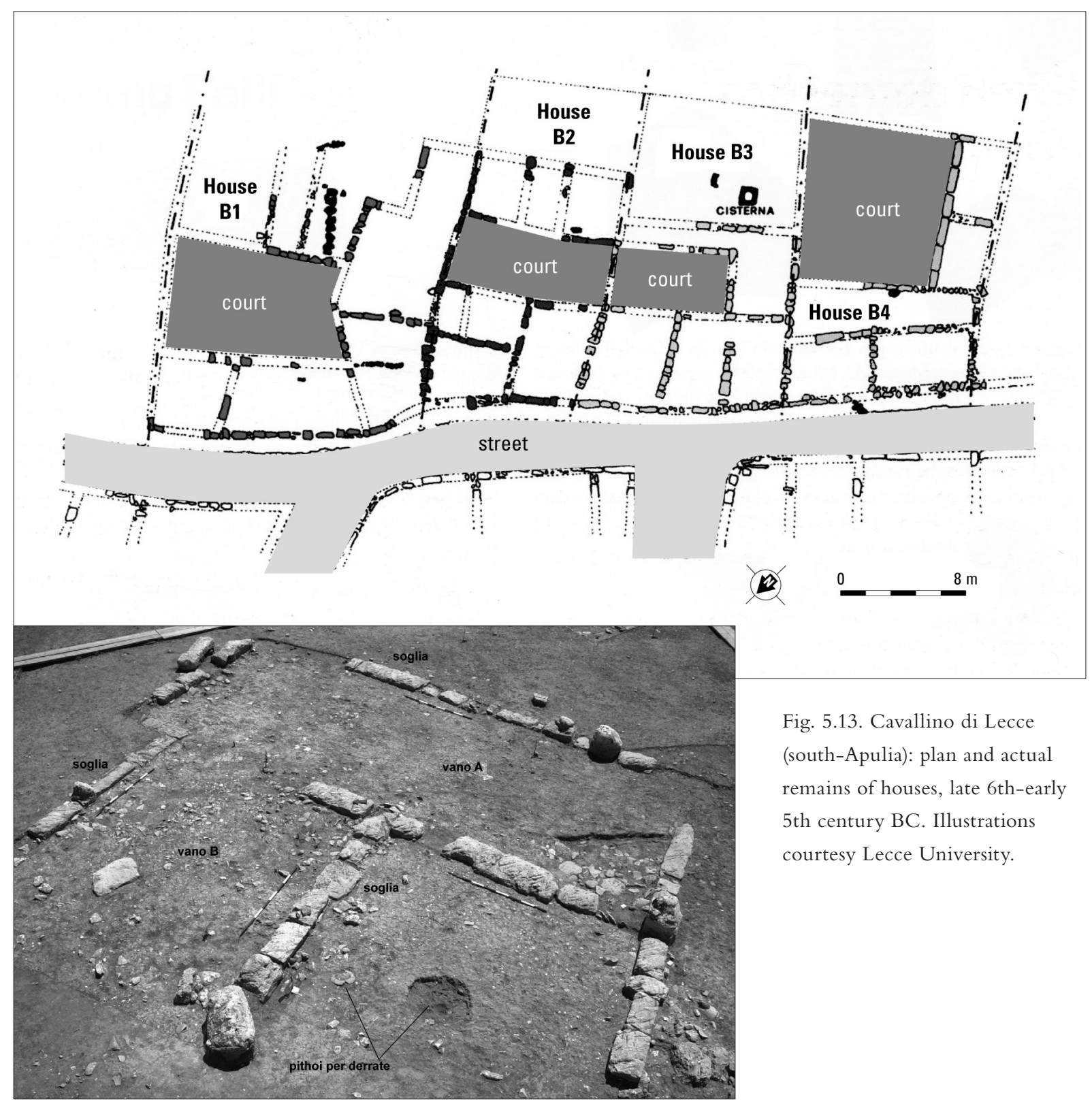

These houses had a more or less rectangular ground plan and consisted of a series of rooms flanking a courtyard. The walls of these dwellings consisted of a lower part made of large and regular blocks of limestone, while the upper part was probably made of mudbrick and/or rubble. The roofs were covered with tiles which must have been supported by wooden beams (fig. 5.13).

In the settlement areas of Cavallino excavated hitherto there are considerable differences between the various dwellings. Though they are all more or less of the same type, they cover a varying number of square meters. ${ }^{42}$ The Cavallino houses were, therefore, probably not exclusively impressive dwellings of the happy few of the settlement: a substantial part of the Cavallino inhabitants of the 6th and early 5 th centuries BC lived in such houses. This information - together with the arrangement of the houses in spatially separated clusters - indicates that a cluster of dwellings was inhabited by a family group or by a small clan.

\footnotetext{
42 Pancrazzi 1979, Russo Tagliente 1992.
} 


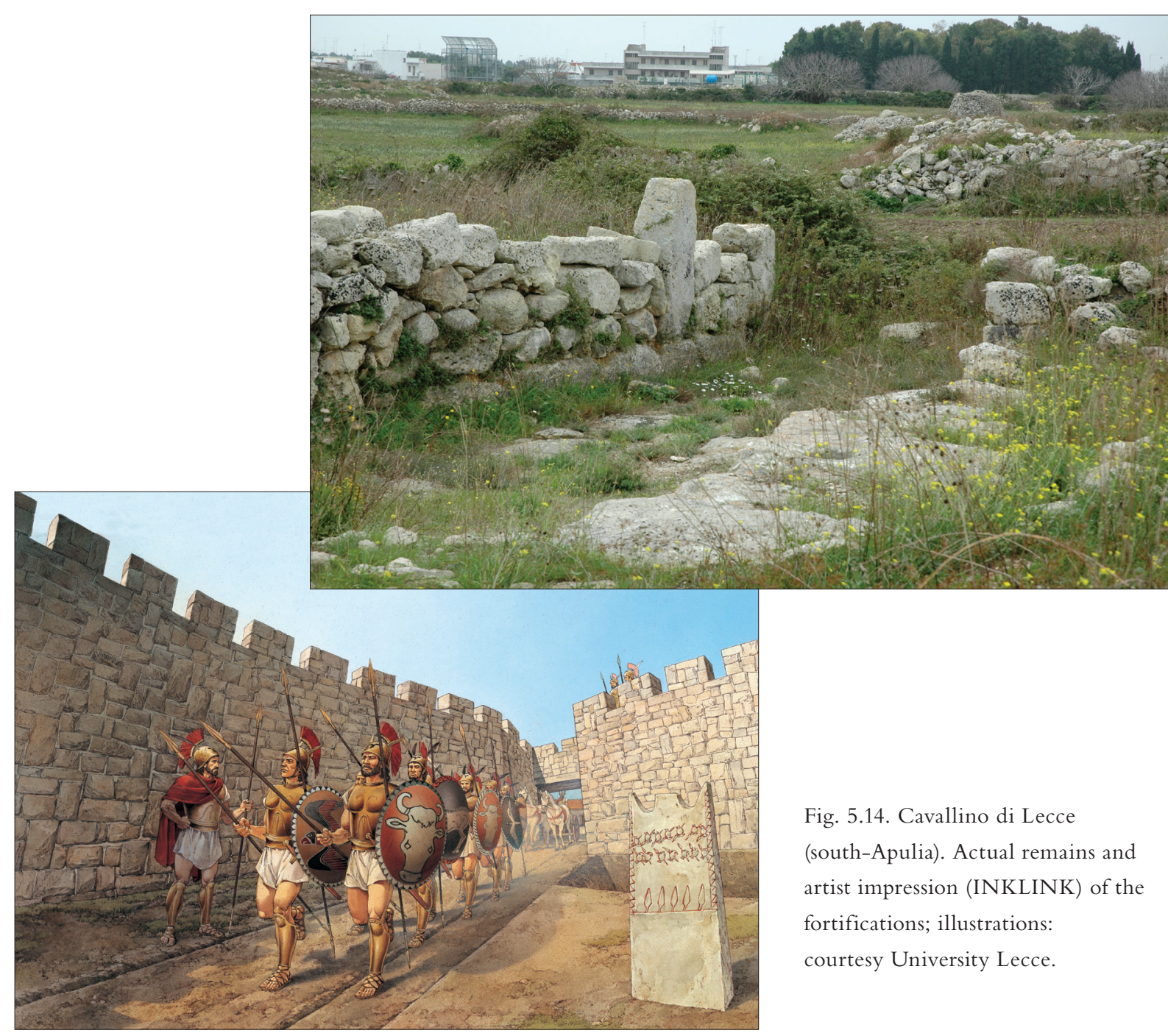

Since intensive field surveys have not revealed the presence of 6th- or 5th-century rural farms in the area surrounding the Salento settlements, these houses and their courtyards are likely to have been farmsteads as well. They must have housed carts, farming implements and plough oxen. Other types of animal husbandry such as flocks of sheep and goats and herds of swine foraged in the fields and in the forests outside the walls of Cavallino and could be brought in for shearing or culling when necessary. ${ }^{43}$ Recent excavations at Cavallino have revealed the presence of animal pens in a peripheral area within the fortifications. ${ }^{44}$ These may have been used to collect sheep, pigs and cattle that usually roamed the wilds, in order to milk, shear or cull them.

The fortifications are likely to have been among the more recent features of the site (fig. 5.14): they probably came into being towards the end of the 6th or in the early years of the 5th century BC..$^{45}$ The defences of Cavallino - approximately $5 \mathrm{~m}$ thick and presumably some 5 to $6 \mathrm{~m}$ high - had an overall length of $3.1 \mathrm{~km}$ and enclosed an area of 69 hectares. It seems that the fortified area was only partly filled in with habitations. In the present state of research the general impression is that clusters of more or less rectangular houses replaced the Iron Age clusters of oval huts. The site of Cavallino di Lecce in its Archaic-Classical phase was basically a somewhat dispersed settlement with various spatial-

43 Veenman 2002.

45 Pancrazzi 1979, 112-114.

44 D’Andria 2005, 40. 

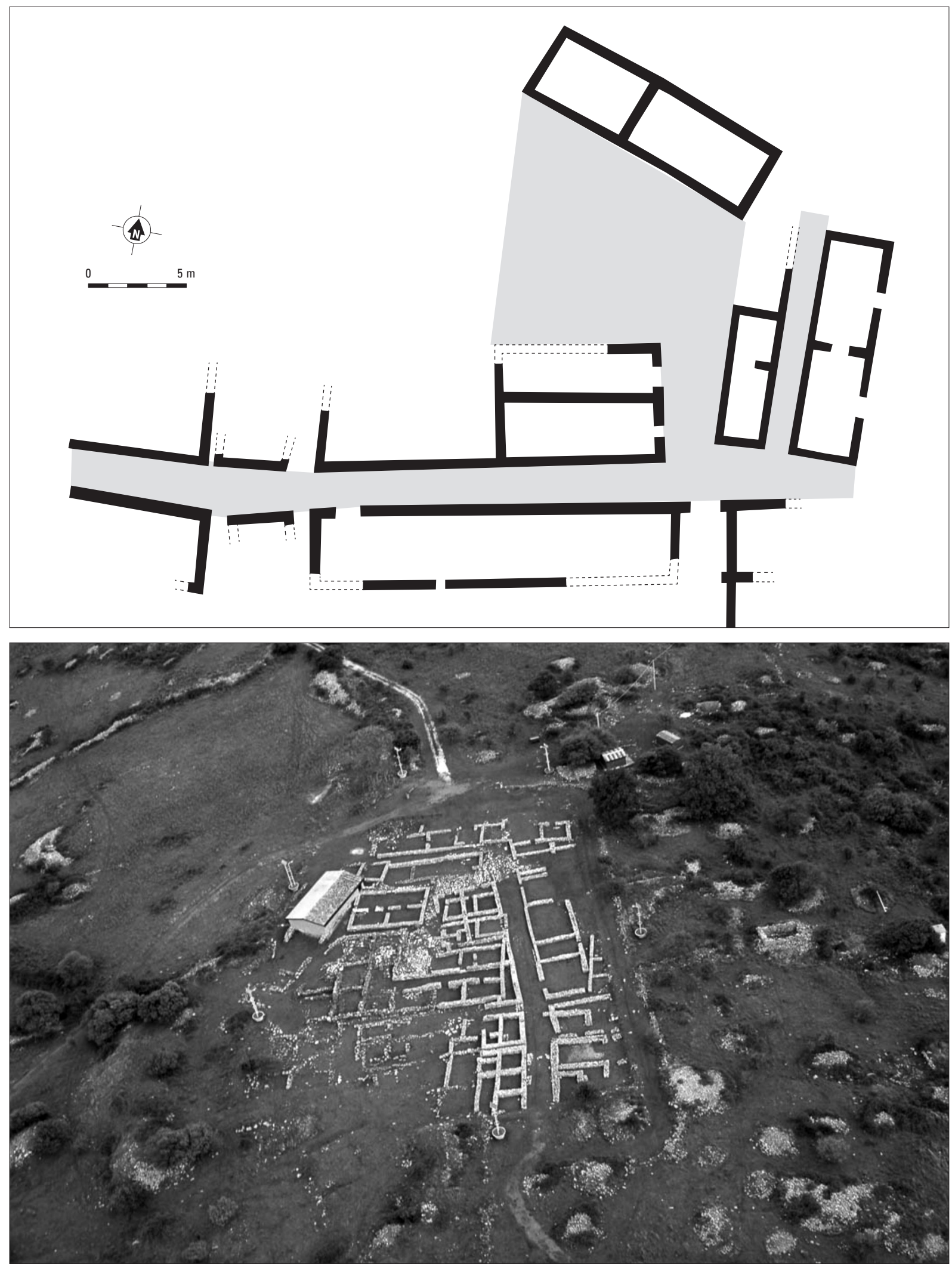

Fig. 5.15. Serra di Vaglio (central Basilicata). above Groundplan of the settlement in the early 5th century BC; after Greco 1991; below 5th and 4th century remains. 


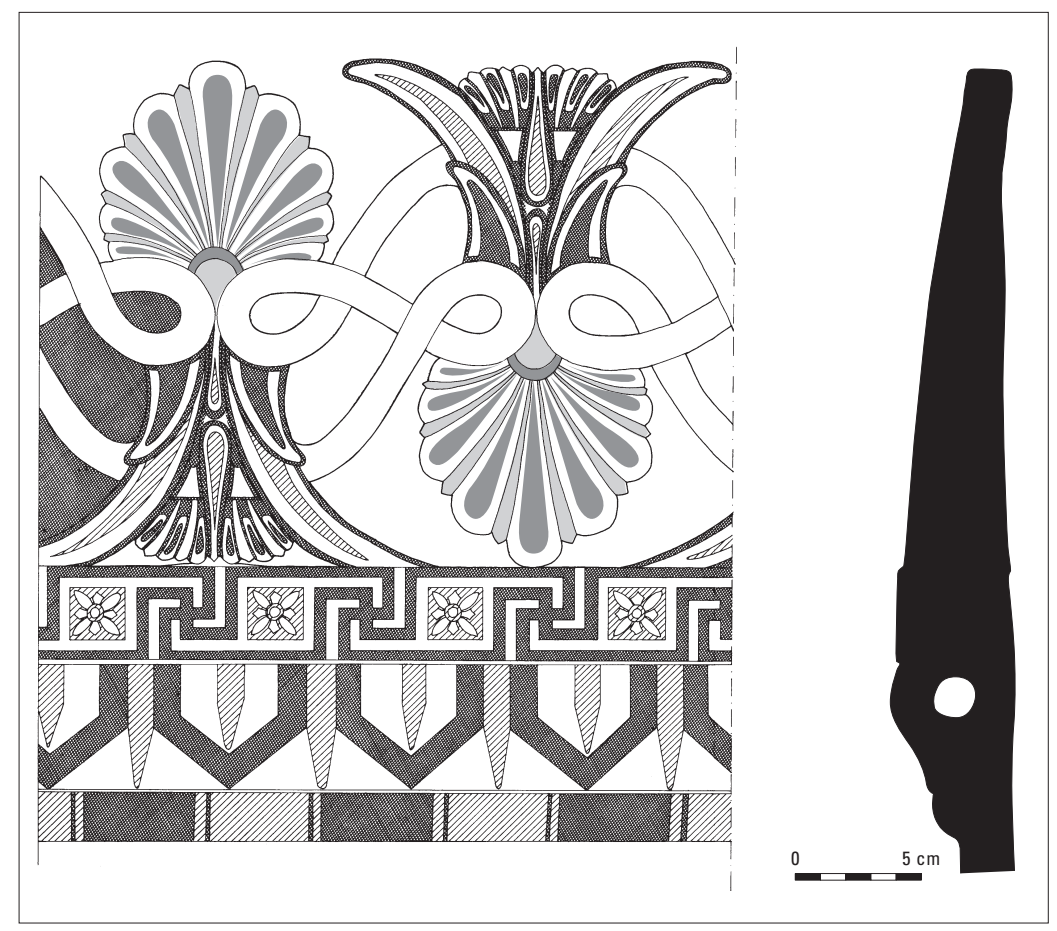

Fig. 5.16. Serra di Vaglio (central Basilicata). Terracotta revetments of buildings on the 'main street' (early 5 th century BC. Adapted from Greco 1991.

ly separated groups of houses surrounded by walls.

Cavallino was not the only settlement outside the coastal strip of the Gulf of Taranto to display signs of incipient urbanization. In Salento (the 'Messapian' district) comparable developments may be surmised to have taken place at the sites of Ugento (southern tip of Salento) and Oria (in the plain on the Salento isthmus). As we have seen above, the latter had a special character as early as the Iron Age by being an unusually large dispersed settlement to Salento standards (well over $100 \mathrm{ha}$ ) and having Bronze Age roots. ${ }^{46}$ Since both Oria and Ugento continued to exist to the present day, a large part of their ancient remains have been covered with (and have probably largely been destroyed by) more recent building activities.

There is also a considerable body of evidence for increasing complexity from the uplands of Basilicata. This new trend was expressed here in the complete rearrangement and the increasingly urban character of the settlement. The key site here is commonly indicated as Serra di Vaglio, some $12 \mathrm{~km}$ east of the present-day regional capital of Potenza (fig. 5.1). It is situated on a more or less oblong plateau on top of the mountain of Serra San Bernardo (1.025 m high) rising above the surrounding valleys. Here, excavations have been carried out since the $1960 \mathrm{~s} .{ }^{47}$ An area of c. 70 x $50 \mathrm{~m}$ in the very centre of the site has been brought to light. In this excavated part of the site, the dispersed hut settlement of the Iron Age appears to have been replaced by buildings having stone bases and more or less rectangular ground plans (fig. 5.15). The 'houses' faced a $4.00 \mathrm{~m}$ wide street that runs lengthwise over the flat top of the mountain. The start of this significant change in the layout and character of the settlement is dated to about the final quarter of the 6th century BC..$^{48}$

The function of the new rectangular structures built at Serra di Vaglio, however, is not clear. Because of the possibly special character of the $s i t e,{ }^{49}$ some of these may have had a ceremonial character, but others were certainly dwellings. ${ }^{50}$ As at Cavallino di Lecce, the Serra di Vaglio buildings of the late 6 th and 5 th centuries were covered with roofs having terracotta tiles. Some even had vividly painted terracotta revetments: elaborately ornamented simas with lotus flowers, palmettes, meandriform patterns and kyma reversa (fig. 5.16).

46 D’Andria et al. 1990; Yntema 1993a.

47 Greco 1988, 1991, 1996.

48 Greco 1996, 273; Osanna 2011, 136.

49 Serra di Vaglio is almost generally believed to be a settlement with supra-regional importance, being the (ceremonial ?) centre of various tribal groups.

50 Greco 1991, and Greco 1996, 284. 
As for Serra di Vaglio, there is no information on the way the inhabitants carried out their agricultural activities. Fieldwork around the neighbouring site of Torre di Satriano suggest that these are likely to have taken place in the valleys surrounding the plateau on which the representative part of the settlement was located. ${ }^{51}$ As for Cavallino, only a short check up was made in the area surrounding the site. ${ }^{52}$ The results were comparable to those obtained at Oria and Valesio in the same district. ${ }^{53}$ In a radius of c. $5 \mathrm{~km}$ around the site no single trace of 'rural' settlements dating to the Archaic-Classical period has been found. This means that the farmers of Oria, Valesio and Cavallino di Lecce probably lived within the settlement and had their fields partly within, but mostly outside the settlement area as delimited by the fortifications. These settlements, therefore, functioned in a way that was perhaps comparable to the sub-recent agro-towns of southern Italy and Sicily: in the early morning the farmers left the town in order to till their fields. The agricultural activities, therefore, are likely to have been carried out in the open areas between the clusters of houses and in the halo of fields surrounding the fortifications of Cavallino.

It should be noted that Serra di Vaglio and Cavallino di Lecce, both with predominantly autochthonous populations, differed in several respects from those coastal settlements of southern Italy that labeled themselves as Greek and that went through the rapid and truly astonishing revolution described in the first part of this chapter: the towns of Sybaris, Siris, Metapontion and Taras on the Gulf of Taranto. Whilst the latter four settlements were designed according to a very strict, orthogonal plan that completely cancelled pre-existing patterns, the traditional layout was in fact respected and remained basically intact at Cavallino. The settlement preserved its dispersed character: the groups of rectangular houses of the Archaic period were a translation of the groups of oval huts of the Iron Age. This means that while pre-existing patterns of landholding and landownership were completely erased at, for instance, Metapontion, they remained basically unchanged at Cavallino. The close similarity between the spatial arrangement of the latter settlement of the Iron Age and that of the ArchaicClassical period, moreover, suggests that the tribal forms of organization remained more or less intact. Cavallino differed also from the four urban centres on the Gulf of Taranto in yet another aspect. It did not have any public buildings, although the construction of the fortifications can undoubtedly be considered to be an effort involving the whole community. More and equally substantial differences can be seen in the organization of the countryside: the orthogonal grid of the rural area of Metapontion against the agro-town-like system in the Salento district.

The construction of sidewalks, drains and tile-covered houses with partly or completely stone walls was doubtlessly a major effort, but it was especially the construction of fortifications at Cavallino and a few other settlements in the Salento peninsula that was most labour-intensive. At Serra di Vaglio, however, situated on a high plateau with steep slopes and defended by nature, much energy was spent on a new spatial arrangement of the settlement that possibly cancelled the pre-existing patterns. ${ }^{54} \mathrm{We}$ have seen that the new houses and buildings, lavishly decorated with brightly painted terracotta revetments, bordering more or less straight streets replaced the dispersed hut settlement. Since the spatial organization and the underlying social structure in the settlements of Cavallino and Serra di Vaglio

51 Osanna 2007: small settlement nuclei surrounding the

flat mountain with prestigious buildings.

52 Field walking in 1990 in a $1 \mathrm{~km}$ wide and $5 \mathrm{~km}$ long transect east of the site of Cavallino revealed a complete absence of 6th- and 5th-century BC finds, whilst there was a considerable quantity of Hellenistic and Roman finds on the surface in various parts of the transect.
53 For the Oria survey, see Yntema 1993a, 171-176; for the Valesio survey, see Boersma et al. 1991.

54 It should be observed that the extension of the excavation area at Serra di Vaglio was limited. A somewhat dispersed form of settlement with various groups of houses with empty spaces in between cannot be excluded in the present state of research. 

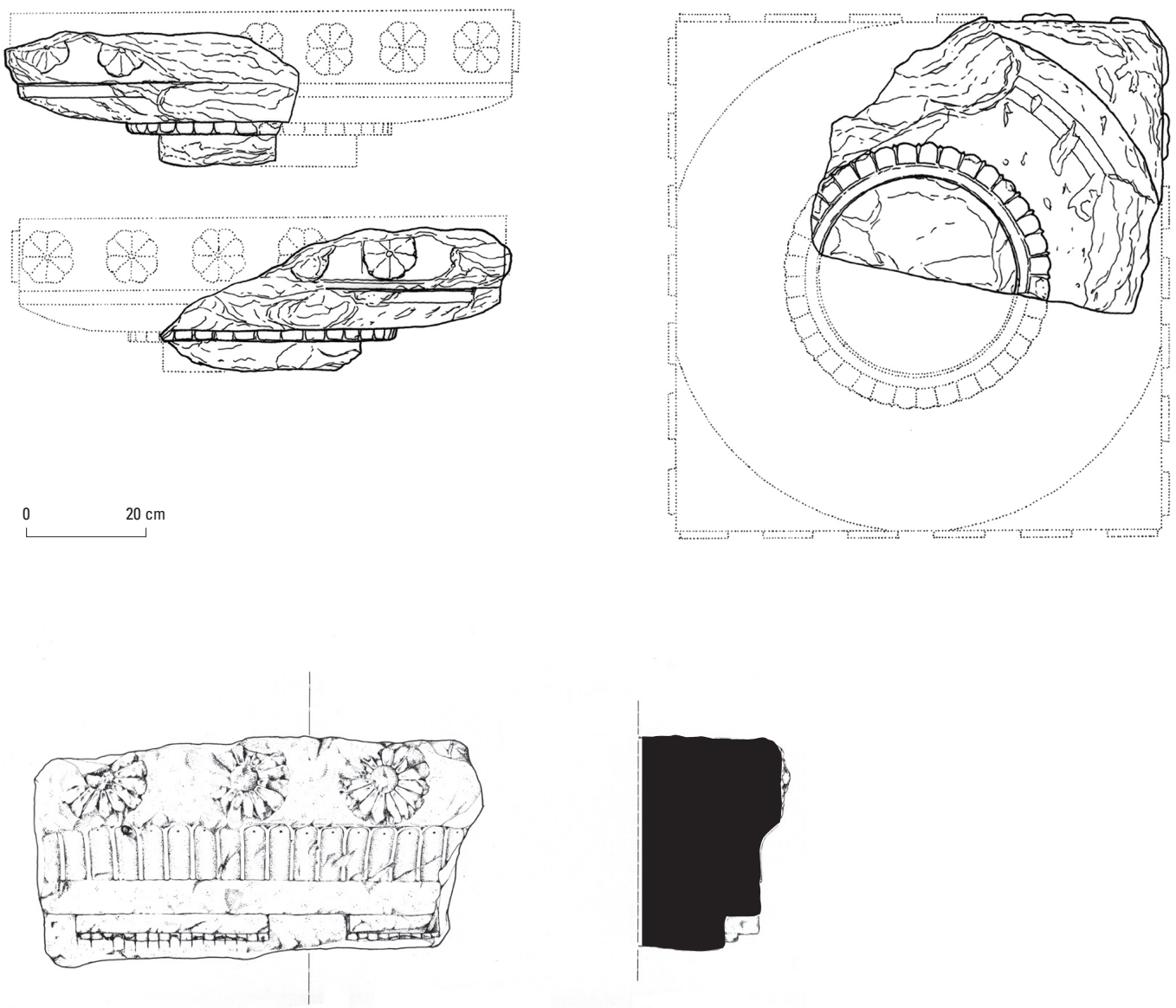

Fig. 5.17. Cavallino di Lecce (south-Apulia). Limestone mouldings and capital (second half of the 6th century BC; after D’Andria 1977).

differed very substantially from those in, for instance, the new urban centres of Metapontion and Taras, the former settlements are usually characterized as proto-urban societies.

These important changes in the architecture of the settlements of Cavallino and Serra di Vaglio went hand in hand with several other, very substantial innovations in the areas of southern Italy inhabited by people who are traditionally indicated as non-Greeks. As we have seen above, the site of Serra di Vaglio has produced a series of terracotta revetments and antefixes of the late 6th, but predominantly of the 5th century BC (fig. 5.16). These, when found in traditional Greek contexts, are often interpreted as parts of religious buildings. Since the revetments were found at a site that was definitely inhabited by a group with non-Greek antecedents, their interpretation requires some caution. Objects passing from one cultural system into another are likely to experience a change of function: they may be translated and used for completely different purposes. This seems indeed to have been the case at Serra di Vaglio, since they are likely to stem from buildings flanking the main thoroughfare, which display no signs of having been used for religious purposes. These revetments therefore, might have decorated the 'houses' on the main road of this important centre in the uplands of Basilicata.

At Cavallino di Lecce, however, both limestone capitals, and terracotta revetments and antefixes have been discovered within the area surrounded by the fortifications (fig. 5.17). These display close 


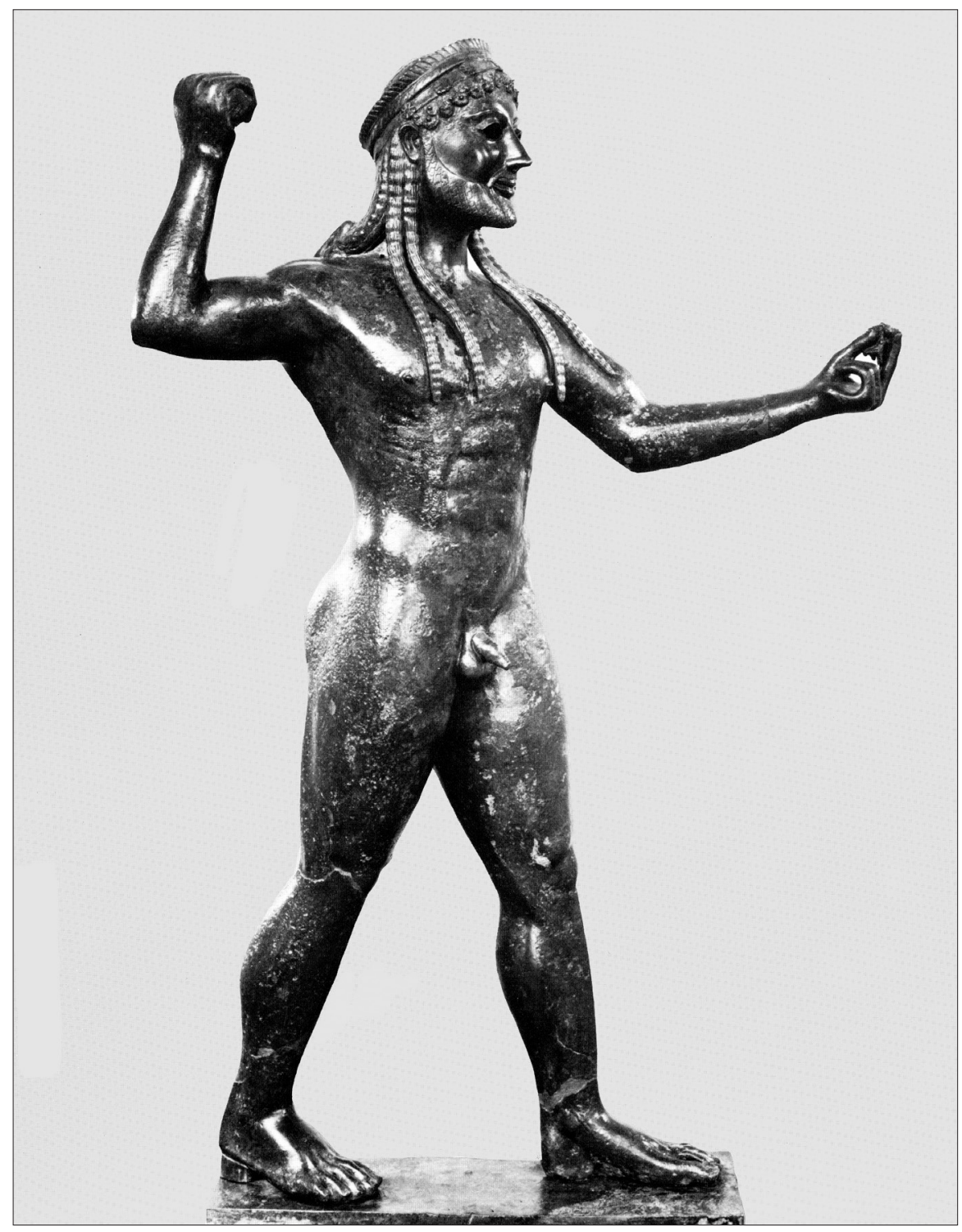

Fig. 5.18. Ugento: bronze statue of god, Height: $0.74 \mathrm{~m}$, late 6 th century BC; Photo courtesy Soprintendenza Taranto.

similarities to specimens found in the Corfu-Epidamnos area on the eastern shores of the Adriatic. ${ }^{55}$ In order to understand the function of the Cavallino capitals, revetment plaques and antefixes we have some assistance from finds from Ugento in the southern tip of Salento. ${ }^{56}$ Here, almost identical revetments were found, whilst a capital could be proven to have carried the $0.74 \mathrm{~m}$ high bronze statue (the so-called 'Zeus of Ugento'; see fig. 5.18). Although the architectonic terracottas from Serra di Vaglio in Basilicata decorated buildings that had presumably no religious function, part of the revetment plaques from the two major Salento sites of Cavallino and Ugento can probably be related to religious activities. They are, therefore, among the first archaeologically legible signs of communal religious activity in non-Greek speaking areas of southeast Italy. In both cases the sanctuaries are likely to have been within the area surrounded by the fortifications.

The sanctuary of Ugento is reconstructed in a tentative way. It is believed to be a sacred precinct containing an enclosure wall that encased a column carrying the image of the god. Within the precinct, in the area surrounding the enclosure, objects offered to the god may have been deposited in a

55 D’Andria 1977, D’Andria 1988; Mastronuzzi 2005, 43-49.
56 D’Andria / Dell'Aglio 2002; Mastronuzzi 2005, 119120. 


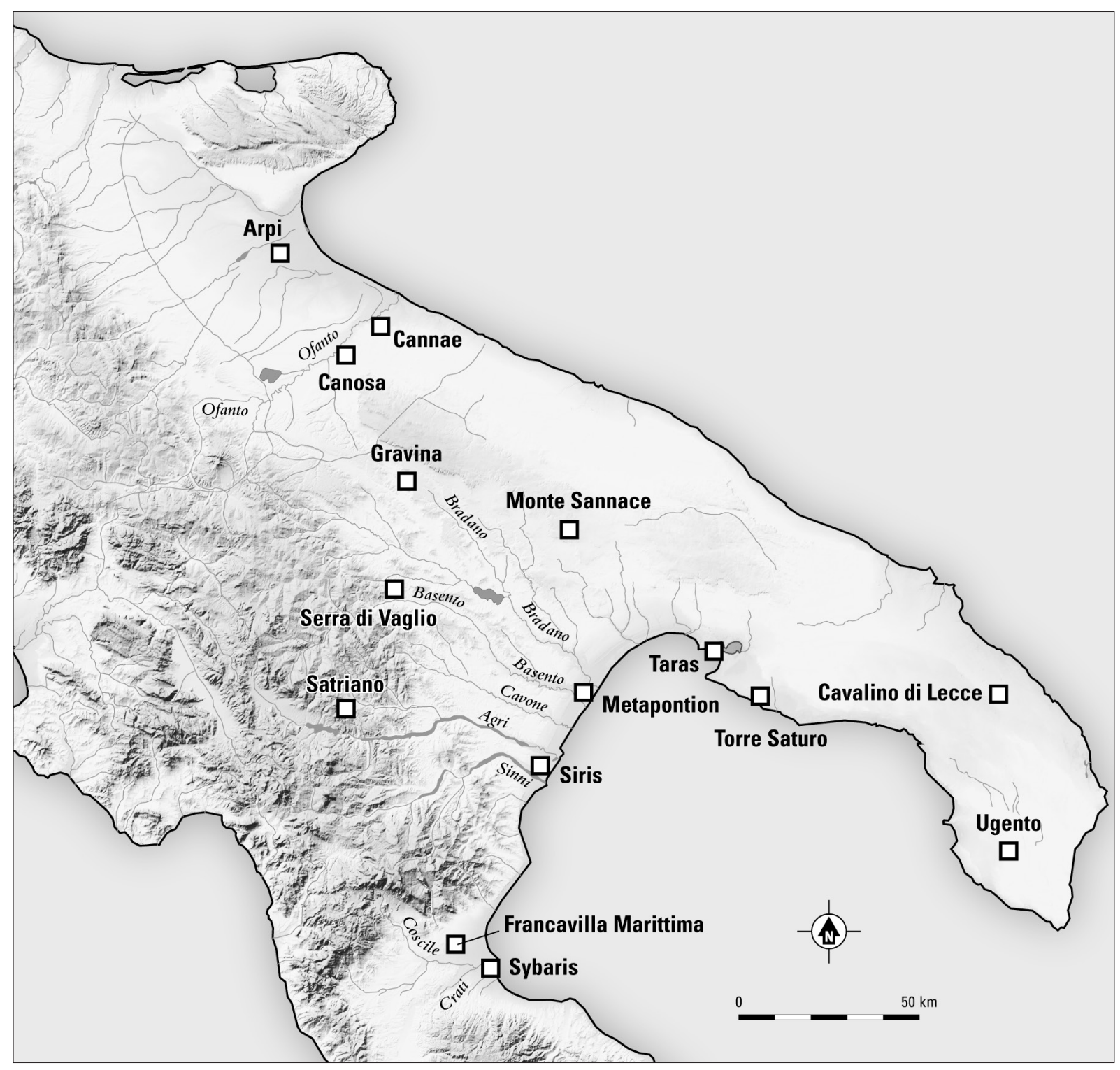

Fig. 5.19. Map showing sites with architectural terracottas of the 6th and 5th centuries BC (antefixes not included).

way that is also found in Greek speaking areas of southeast Italy. Such votive offerings were actually found at the major Salento site of Oria. Here a hill close to the 6th-5th century BC settlement area appeared to have contained the important Monte Papalucio cave sanctuary (fig. 5.37)..$^{57}$ The 6th- and 5th-century votive deposits of this sanctuary show that ceramics, coins, terracotta statuettes, meat (mainly piglets) and vegetables (plant remains: predominantly corn and beans) were offered to the local gods. ${ }^{58}$ These were probably vegetation goddesses that bear distinct similarities to the Greek goddesses Demeter and Korè. There is, however, no trace of 6 th - or 5th-century building activity at Oria. ${ }^{59}$ The ritual depositions were made in front of a cave. The sacred precinct of Oria, moreover, was by

57 D’Andria et al. 1990, 239-306; Mastronuzzi 2005, 83-87.

58 Ciaraldi 1999.

59 The late 6th to 5th century antefixes recovered at
Monte Papalucio have not necessarily been part of a building. The sacred building excavated at Monte Papalucio can be dated to the 4th century BC (D’Andria et al. 1990). 

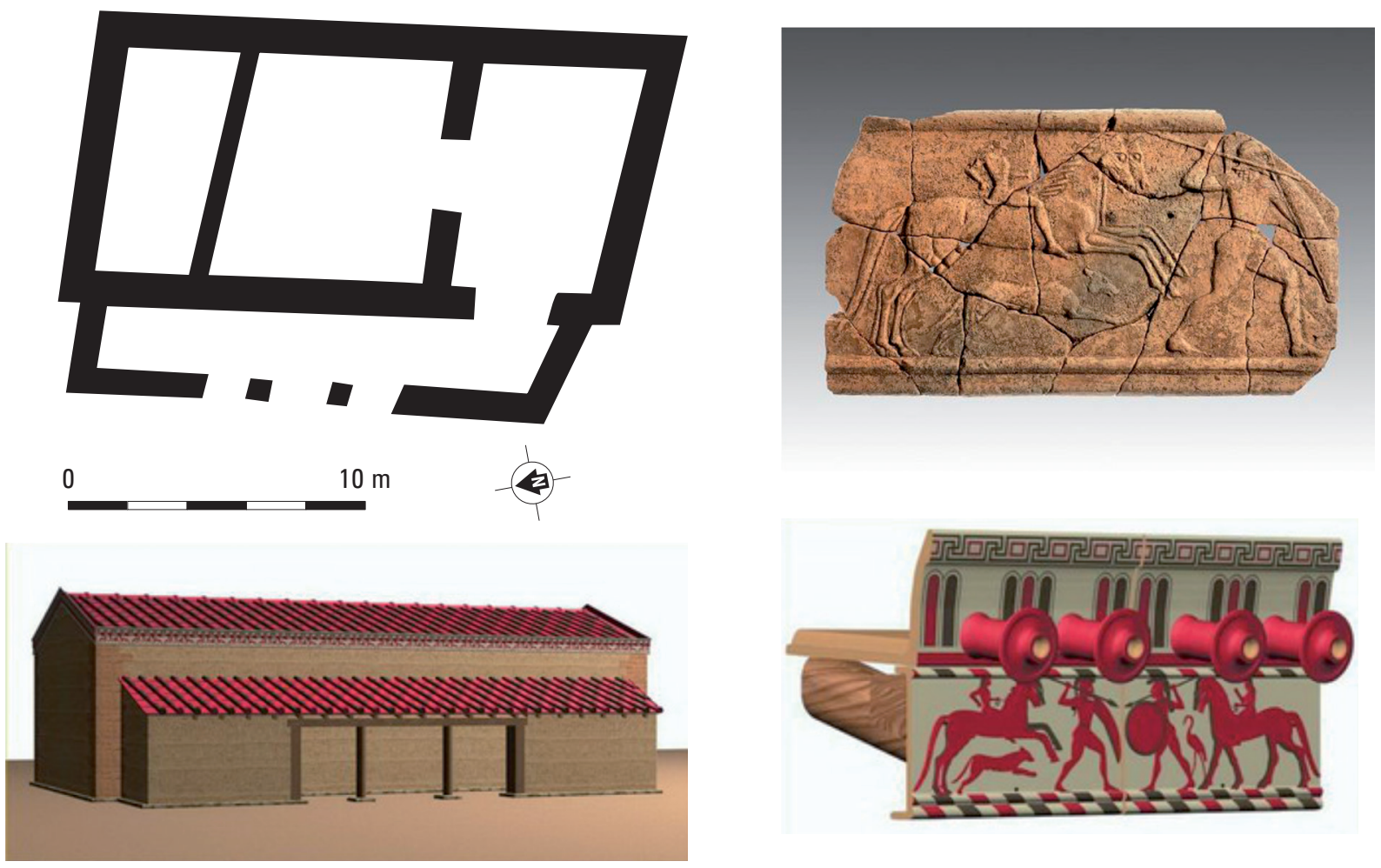

Fig. 5.20. Satriano (central Basilicata): groundplan, reconstruction and terracotta revetment of aristocratic dining hall (6th century BC). Illustrations courtesy Matera University.

no means the only cave of the Salento district displaying traces of religious activities during the 6th and 5 th centuries BC. ${ }^{60}$

The sudden visibility of religious activities in areas outside the territories of the new, to all appearances Greek towns of Sybaris, Siris, Metapontion and Taras was probably limited to the Salento peninsula only. In Basilicata and central and northern Apulia legible traces of religious activities in the nonGreek areas are absent or very faint indeed for the Archaic-Classical period. ${ }^{61}$ They consist of only a few portable finds which might or might not be interpreted as signs pointing at the presence of a sacred place. They are mostly found in Basilicata in those areas that are close to the chorrai of the Greek poleis. ${ }^{62}$ Of course, this does not mean that there were no religious activities in these districts in which larger groups participated. If they left any signs in the archaeological record, we are unable to read them in the present state of research.

We have seen that columns, capitals, simas and architectural terracottas are often linked with religious activities in both the Greek poleis of southeast Italy and in the non-Greek world of Salento. Similar objects from the non-Greek areas of Basilicata and northern Apulia have often been interpreted in

${ }^{60}$ Ostuni: Grotta di S. Maria di Agnano (Coppola 1983); Ceglie Messapico: Grotta San Niccolo Abbate; Rocavecchia: Grotta della Poesia (Pagliara 1987 and 1989); Ruffano, Grotta Trinità (D’Andria et al. 1990, 195-196); Leuca: Grotta Porcinara (D’Andria1978); S. Caterina di Nardò: Grotta di Capelvenere (Borzatti von Löwenstern 1961).

61 For an early sacred place at the site of Garaguso (Basilicata), close to the Metapontion territory, see Morel 1974.

62 Cf. Morel 1974 (Garaguso) 
the same vein. Recently most of the antefixes and revetments have been collected and analyzed. They stem almost exclusively from the Metaponto hinterland and the north-Apulian Ofanto district. ${ }^{63}$ Some caution in the interpretation of these finds, however, is needed. As we have seen above, the terracotta revetments of Serra di Vaglio are likely to have functioned in a non-religious context. The same observation may hold for the so-called frieze of the enigmatic Braida building near the foot of the Serra di Vaglio plateau. This building, consisting of rooms around a court surrounded by a porticus, is now believed to have been a princely dwelling or an aristocratic dining hall. ${ }^{64}$ There is a good chance that the Italic groups of Salento appropriated both Greek revetments and the context (religious) in which the Greeks used them, while the Italic groups of Basilicata and northern Apulia adopted only the objects and applied them in an entirely new context (decoration of prestigious dwellings and/or chieftain's dining halls). ${ }^{65}$

The data concerning the societies in the vast areas outside the territories of the urban settlements indicate that these differed in several respects from the four Greek polities on the coast. The spatial organization of the settlement of Cavallino di Lecce that consisted of somewhat dispersed groups of houses within fortifications, suggests that family groups and family allegiance continued to be basic elements in the local society. The various family groups lived in spatially separated habitation nuclei. The cohesion between these different family groups, however, was strong. They succeeded, perhaps with the help of the inhabitants of dependant settlements in the same area, in constructing the imposing $3.1 \mathrm{~km}$ long fortification wall. Whilst the organization of the settlement indicates that Cavallino was basically a tribal society, the fortifications suggest that there was a fairly strong central authority in the 6th-century settlement.

Cavallino, moreover, was not unique. It may indeed have been a major tribal centre in the Salento district together with Oria and Ugento. Serra di Vaglio with its Braida dining hall and its houses and street is also likely to have been a settlement with a special status in central Basilicata. A similar observation can be made concerning the north-Apulian site of Arpi which continued to have a highly dispersed character. In the earlier 6th century BC it was clearly separated from the surrounding area. Its impressive, $7 \mathrm{~km}$ long earthworks and the approximately 1.000 hectares included by them have been discussed in the preceding chapter (4.2).

In addition to major centres such as Cavallino and Serra di Vaglio there was a host of smaller settlements of probably lesser importance. The discovery of the important 'anaktoron' of Satriano dating to the late 6th-early 5th century and situated at a relatively short distance from Serra di Vaglio, suggest that powerful chiefs could also be found in other settlements (fig. 5.20). ${ }^{66}$ The character of the settlement hierarchy differed from district to district. In the slightly hilly sub-coastal area of Basilicata, there

63 The stem from the sites of Serra di Vaglio and Monte Sannace (in the Metapoto hinterland) and Lavello, Canosa-San Leucio, Canosa-Toppicelli and CanneAntenisi (in the north-Apulian Ofanto district); see Dally 2000, 29-66). Recently revetment plaques of the late 6th century have also turned up at Torre di Satriano (Osanna 2009).

${ }^{64}$ Initially the relief-decorated terracotta frieze from Serra di Vaglio-Braida was believed to have belonged to a religious building (Lo Porto / Ranaldi 1990), since it has such close parallels in friezes from sacello C in the very centre of Metapontion and from the rural sanctuary of San Biagio alla Venella (chõra of Metapon- tion). For the function of Braida building, see e.g. Greco 1996, 268-271 and 284, and Tagliente 1999, 15, Osanna 2011, 134.

65 We may assume that the dining halls were not exclusively used for aristocratic feasting, but were also places where elite rituals were performed. The Braida dining hall at Serra di Vaglio is close to a well (Tagliente 1999, 15) which appears to be a standard element in elite rituals in Basilicata from the late 5th century onward (see chapter 6). See also Semeraro 2009 (San Vito).

66 For the anaktoron of Torre di Satriano, see Osanna 2009 and Capozzoli / Osanna 2009. 


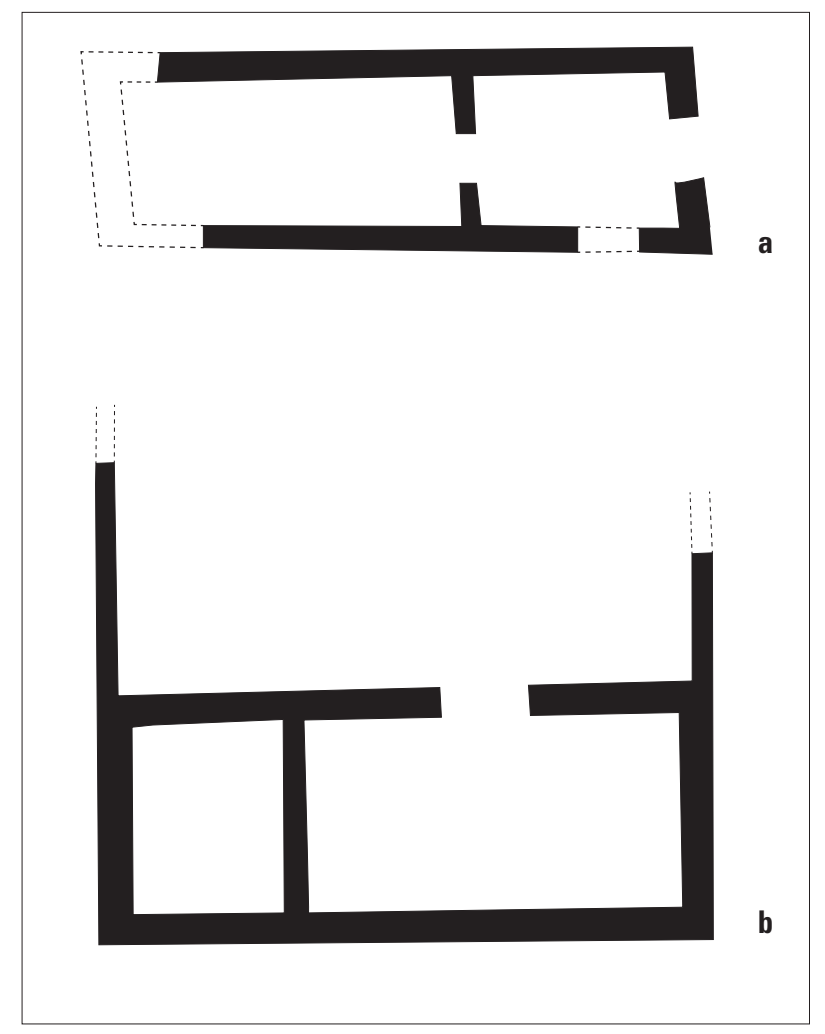

Fig. 5.21. Houses of the late 6th and early 5th centuries from Rutigliano (a) and Monte Sannace (b), central Apulia (adapted from Ciancio 1989).

are no great differences between extensions of the various settlements. In the uplands of Basilicata, Serra di Vaglio was surrounded by quite a series of other hilltop sites of presumably lesser importance. ${ }^{67}$ It is still uncertain whether these settlements all had more or less the same settlement history and existed as early as the 6 th or 5 th century BC. ${ }^{68}$ Two of these, Satriano (at c. $920 \mathrm{~m}$ ) and Oppido Lucano (at $670 \mathrm{~m}$ ) have been the objects of more intensive research. ${ }^{69}$ Till well within the 5 th century BC small nuclei of habitations were dispersed both over the plateaus of the mountains on which they stood and in the surrounding valleys. In the Salento peninsula Oria is one of the key sites. The settlement is likely to have been the central place for a series of smaller sites in the northern Brindisi plain. ${ }^{70} \mathrm{~A}$ similar pattern can be observed in the Bari area. Here the large and prosperous settlement of Rutigliano-Castiello appears to be surrounded by a group of smaller settlements in the 5 th century BC. ${ }^{71}$

Whether there was a distinct settlement hierarchy in the 'Daunian' districts of northern Apulia (basin of the lower Ofanto, north-Apulian Tavoliere plain) is uncertain. Here highly dispersed forms of settlements continued to live on. Since Canosa was the most important settlement of the lower Ofanto district between c. 700 and $500 \mathrm{BC}$ and was demonstrably the dominant settlement in the same area from about $370 \mathrm{BC}$ onward, one may suggest that it played a similar role in the intermediate period. ${ }^{72}$ The settlement of Arpi may well have played a comparable role in the north-Apulian plain, dominating in some way a series of settlements of probably lesser importance. ${ }^{73}$ In the north-Apulian dis-

${ }^{67}$ For instance, the sites of Civita di Tricarico, Serra del Cedro, Cancellara, Oppido Lucano, Torretta di Pietragalla and Croccia Cognato.

68 Satriano, Oppido Lucano and Torretta di Pietragalla were certainly inhabited from the Iron Age to within Hellenistic times. On the sites of Serra del Cedro, Cancellara, and Croccia Cognato the information is scanty. Civita di Tricarico seems to have been a centre of major importance in Hellenistic and early Roman times (cf. de Cazanove 2001).

69 For Satriano, see Holloway 1970; Greco 1988; Nava / Osanna 2001, Osanna 2009; Osanna / Sica 2005; for Oppido Lucano, see Lissi Caronna 1972, 1980, 1983 and 1990/91.
70 E.g. the sites of Muro Tenente, Mesagne, Muro Maurizio, San Pancrazio; cf. Burgers 1998.

71 See Ricardi 1999; for the wealth of Rutigliano, see a selection of the burials in the yearly reports on the excavations in Apulia by F.G. Lo Porto in Atti Convegno di Studi sulla Magna Grecia, Taranto (1974-1980); De Juliis 2006. For bronze objects from these graves, see Tarditti 1996.

72 Settlements of somewhat lesser importance in this same district were Minervino Murge, Lavello, CanneAntenisi, Barletta and Salapia.

73 In the Tavoliere district sites such as Troia, Ordona, Siponto, and San Severo may have been dominated in some way by Arpi. 


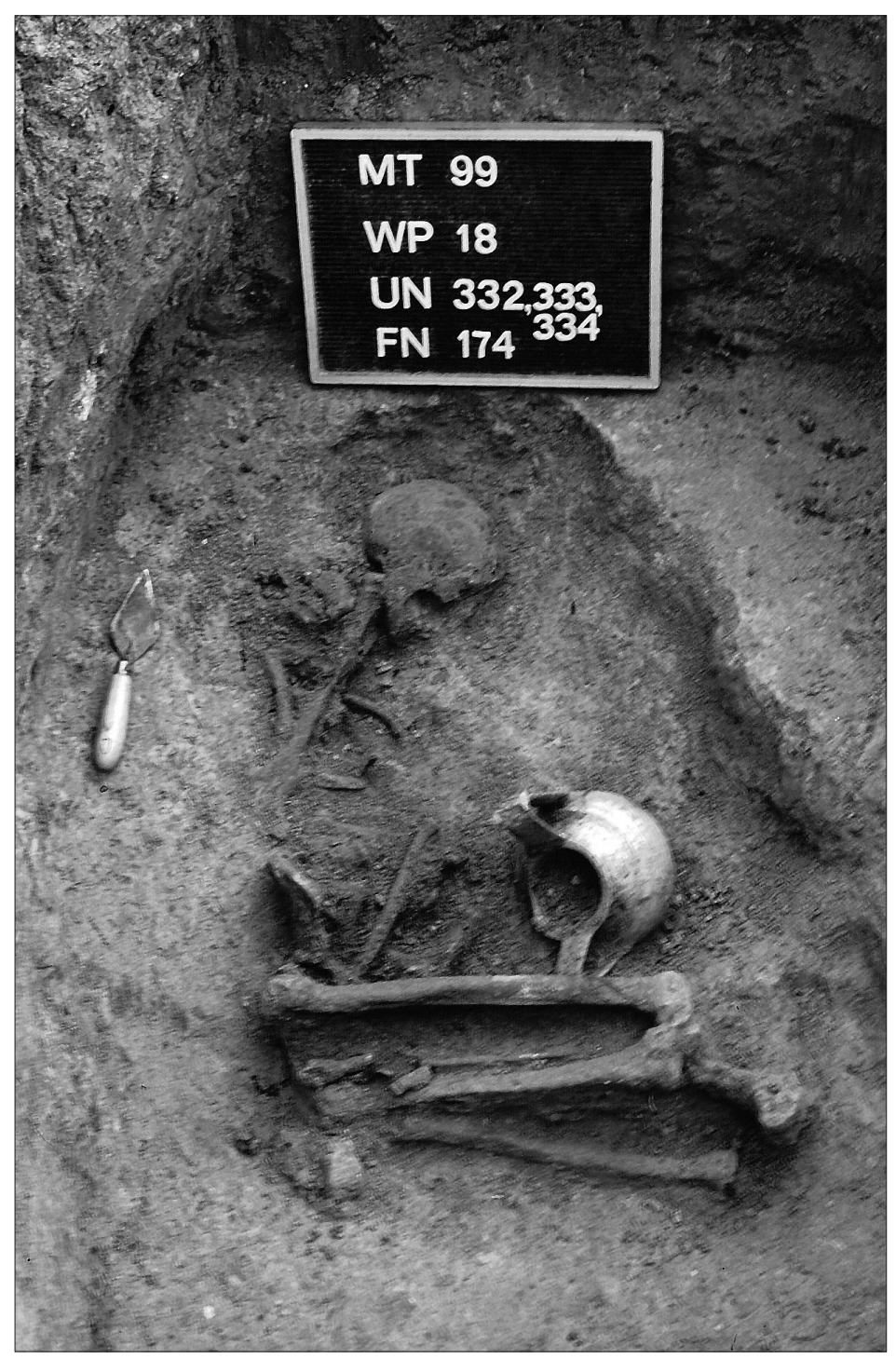

Fig. 5.22. Muro Tenente (south-Apulia).

Burial of a c. 25 year old woman (with trozzella), later 5th century BC;

photo archive ACVU.

tricts, however, the signs suggesting a clear settlement hierarchy are much weaker than in the remaining parts of southeast Italy.

The settlement hierarchy was only partly reflected in the sanctuary hierarchy and these reflections are exclusively found in Salento. It is probably not due to coincidence that Greektype terracotta revetments were found at two sites with a special status (Cavallino and Ugento). The sacred, however, was a rather complex matter in southeast Italy and requires a careful further study. We have seen sanctuaries of probably more than local importance (Oria, Ugento). In addition to these there were sanctuaries of purely local importance, ${ }^{74}$ and small sanctuaries of decidedly sub-local importance. ${ }^{75} \quad$ Moreover, there were sanctuaries that cannot be related to settlements. ${ }^{76}$ The location of the sanctuaries coincided partly with human settlement (sanctuaries within or close to settlements), but could also depend on the natural feature where a deity was believed to reside (sacred caves, sacred springs or wells).

Signs suggesting substantial innovation and change in the character of settlements and in the religious sphere can be found at a considerable number of sites during the 6th century BC. The Iron Age huts were replaced by houses in almost every part of southeast Italy. It happened in Salento, in large parts of Basilicata and in the district surrounding Bari (fig. 5.21). ${ }^{77}$ Not every site had large fortifications

74 In south-Apulia sanctuaries of probably local importance have been traced at Valesio (Boersma et al. 1991, 124-131), Ostuni-S. Maria d' Agnano (Coppola 1983, 239-243), and Ceglie Messapico-S. Niccolo Abate.

75 A small sacred place of the 6th to early 5 th centuries BC with limestone cippi and small votive deposits has been excavated within the settlement of Vaste (southApulia); see D'Andria et al. 1990, 58-65. It might have been the religious focus of one of the local clans or family groups of Vaste.

76 Sacred places that were not directly linked to settlements of some substance in south-Apulia are LeucaGrotta Porcinara (D'Andria1978) and Ruffano-Grotta Trinità (D'Andria et al. 1990, 195-196).

77 For site hierarchy in Salento, see Burgers 1998; for Bari district, see Ciancio 1989; for Basilicata, see Gualtieri 1987, Barberis 1999. 
or buildings elaborately decorated with architectural terracottas. Sites lacking these features were invariably relatively small. This means that it was in the 6th century BC that a distinct site hierarchy emerged in nearly every part of southeast Italy. The character of this site hierarchy differs from district to district. As we have seen above, it consisted of the urban centres, villages and isolated farmsteads in the polis areas on the Gulf of Taranto. In Salento, in the Bari area and much of Basilicata the site hierarchy was made up of major and minor tribal centres. In the basin of the river Ofanto and in the Tavoliere of northern Apulia, however, highly dispersed forms of settlement lived on to well into the 4th century BC, but here Arpi and Canosa were probably the most dominant centres. These two 'Daunian' areas that were foci of interregional exchange from the 8th century to within the second half of the 6th century $\mathrm{BC},{ }^{78}$ hardly participated in the far-reaching changes that took place in other parts of southern Italy during the 6th century BC. Their societies were and continued to be similar to those on the central and northern Adriatic.

In the district of the populations that spoke Oscan and Messapic, innovations can be seen which were more or less comparable to those observed in the urban centres that considered themselves as Greek poleis. In both areas the spatial organization of the settlement is indicative of increasing socio-political complexity. Sometimes pre-existing patterns were completely cancelled. It happened at indigenous Serra di Vaglio in a manner that was somewhat similar to the new and regular town plan of 6th-century Metapontion. Often, however, the traditional Iron Age layout was more or less retained: clusters of 6th-century houses replaced clusters of 7th-century huts. Not every settlement of the indigenous districts was affected by these phenomena at the same time and with the same intensity. Initially many smaller settlements changed only marginally. These urbanizing trends, moreover, did not reach northern Apulia before the 3rd century BC.

The differences between the Greek town (e.g. Metapontion) and the major tribal centre (e.g. Cavallino, Serra di Vaglio) should not be overestimated. As has been said above, the image of the polis as a settlement densely packed with insulae or strigae of dwellings certainly does not hold good for 6th century Metapontion. The town had a spectacular centre with its public and sacred buildings, but the infill of the orthogonal plots with houses was a gradual process that took many decades. ${ }^{79}$ The main differences between Greek and indigenous in this respect are (a) the absence of large public and sacred buildings and (b) the absence of an inhabited rural area in the tribal districts.

In the course of the 6th century BC the sacred became visible in one of the tribal areas (Salento). This happened because now votive objects were deposited in the sanctuaries. The favour of the indigenous deities or spirits could now be won by offering them gifts that survive in the archaeological record. These were almost invariably of Greek type.$^{80}$ Architecture was rare in indigenous sanctuaries and occurred mainly in larger tribal centres (e.g. Cavallino, Ugento). Most of these sacred places will have consisted exclusively of a temenos (sacred precinct) with cave or spring/well and bothroi (votive pits).

78 Yntema 1979; chapter 4.4 above.

79 Carter 1998a, 8.

80 In addition to the vegetal remains and animal bones, wheelmade ceramics, Greek coins, and Greek jewellery were deposited in indigenous sanctuaries. It is per- haps significant that the traditional native handmade ceramics (Matt-Painted wares, Impasto pottery) that continued to be produced during the 6th century, are extremely rare in indigenous sanctuaries. 


\subsection{B URIAL A N D THE RISE OF LOCAL A N R REIONAL E L I T E S}

Iron Age burials have been reported from all districts of southeast Italy except for the Salento peninsula. In this period, burials customs seem to have prevailed in this district that left no trace in the archaeological record. In the late 7th or early 6th century formal burials also make their appearance here. These burials display close similarities to burial customs in adjoining areas. They are invariably inhumations: the deceased was deposited in a rectangular grave that was dug into the soil or hewn into the rock. He or she (both sexes are represented) was put on the flank with the legs drawn up. For much of the 6th century BC little energy is spent on the burials in Salento. The tombs themselves are simple and the contents are mostly modest (fig. 5.22). Since they occur in limited quantities, there is reason to believe that a particular, fairly small group within the Salento societies received a formal burial and that the majority of the population cannot be traced in the funerary record of 6th- to 5thcentury BC Salento.

In the preceding chapter on the Iron Age we have seen the presence of local elites in those parts of southeast Italy that had burial rites that can be traced by archaeologists (see chapter 4.5). The most spectacular burials manifested themselves in those areas that played a crucial role in interregional exchange circuits. Canosa and its Ofanto district in northern Apulia, for instance, was pivotal in exchanges between southern Italy and the eastern Hallstatt province (Istria, Slovenia), and Alianello mediated between the emporion settlement of Siris on the one hand and the uplands of Basilicata and southern Campania on the other hand.

By the 6th century BC, however, every settlement of southeast Italy can be shown to have had its local elite families. The main body of evidence for the general emergence of local elites consists of elite graves. These are found in both the indigenous settlements and the emerging Greek poleis. Since Siris eclipsed or had a severe set back in approximately the 3rd quarter of the 6th century BC and Sybaris is buried under a thick stratum of alluvial deposits, the examples of such graves from poleis must necessarily stem from Metapontion and Taras. We have seen above that the new urban centres and their territories had a strict separation between cemeteries and habitation areas. In the large Taranto necropolis well over 70 elite burials have been traced dating between the 6th and the early 4th century BC. ${ }^{81}$ In the past years the numerous Taras graves have been the object of a major research project in which German scholars cooperated with archaeologists of the Soprintendenza alle Antichità. Therefore, we shall focus here on the necropolis of Taras.

The elite graves of Taras do not cluster in a particular spot. They are dispersed over the necropolis area, but the reason behind this distribution is unclear (fig. 5.23). The first signs of ostentatious display in the funerary sphere can be observed as early as c. $580 \mathrm{BC}$. Both the quantity and quality of the objects deposited in the sarcophagus and cist graves for the elite are high. The grave goods of these 6th-century $\mathrm{BC}$ graves all belong to the world of symposium and banqueting (e.g. kylikes, skyphoi, amphorae, hydriae). In the $3 \mathrm{rd}$ quarter of the 6th century BC monumental architecture makes its appearance in the funerary sphere. The most striking specimens were the substantial subterranean chamber tombs. They were carved into the limestone banks on which Taras stood (fig. 5.24), being obviously family burial chambers that were used for two or more generations. These measured approximately 5 x $5 \mathrm{~m}$ and had one to four Doric columns in order to support a roof. ${ }^{82}$

Such family chamber tombs, however, were fairly uncommon in the 6th and 5th centuries BC and were used by only a few families of Taras. The vast majority of the elite in both Taras and Metapontion preferred individual graves ('half-chamber' tombs, large cist graves, sarcophagus burials) (fig. 5.25).

81 Lippolis 1994a.

$82 \quad$ Maruggi 1994. 


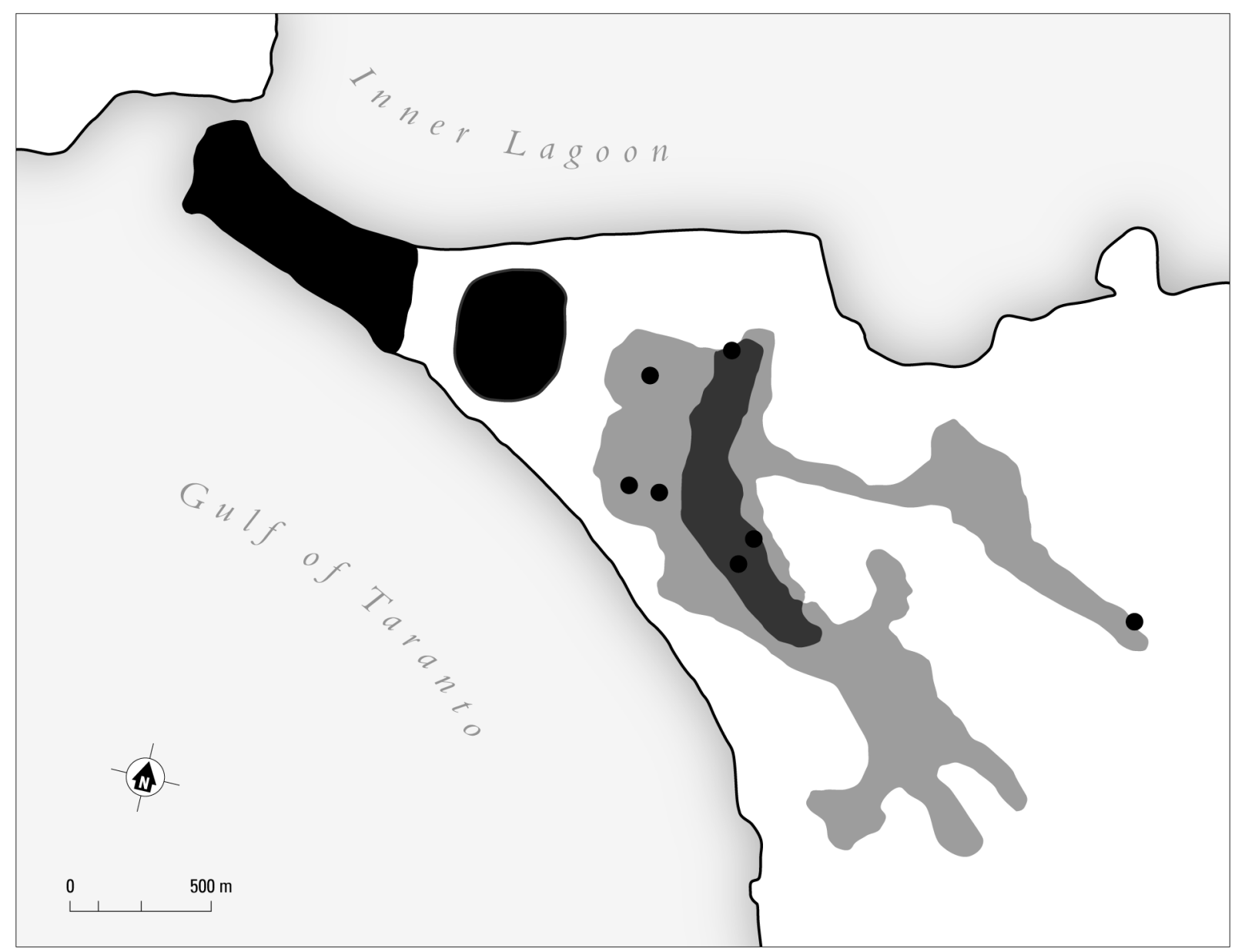

Fig. 5.23. Taras. Plan of the necropolis of the 6th and 5th centuries BC, based on Lippolis 1994a; habitation areas dark grey; necropolis middle grey and light grey; dots: elite graves.

In the early 5 th century BC a slight change can be detected in the elite graves of Taras: objects referring to athletic activities (e.g. strigiles, alabastra) were added to the repertoire of burial gifts. From that moment onward both banqueting and athletics were the main elements stressed in male elite burials. The grave forms and grave goods of Archaic/Classical Metapontion did not differ significantly from those of Taras in either type or contents. ${ }^{83}$

In those areas that were outside the territories of the urban centres, comparable elite graves occurred. As we have seen above, the Salento district was slow in developing an archaeologically traceable way of burying the dead. Here elite graves made their appearance in the first half of the 5 th century BC. ${ }^{84}$ In all remaining districts elite graves can be found from the very beginning of the Archaic-Classical period. These differed from those near the urban centres in several respects. They invariably lacked the impressive architectural outfit that characterized the tombs of a handful of Taras families and were usually not clearly separated from the habitation areas. In the proto-urban settlements outside the territories of the Greek poleis small groups of graves were in close proximity to the dwellings and small children could even be buried underneath the houses in enchytrismos graves (inhumation in large ves-

83 Carter 1998a; De Juliis 2001

${ }^{84}$ See, for instance, Arias 1969 (Cavallino), D’Andria et al.1990, 78-80 (ripostiglio 567) and 83-85 (deposito funerario 565), both from Vaste. 


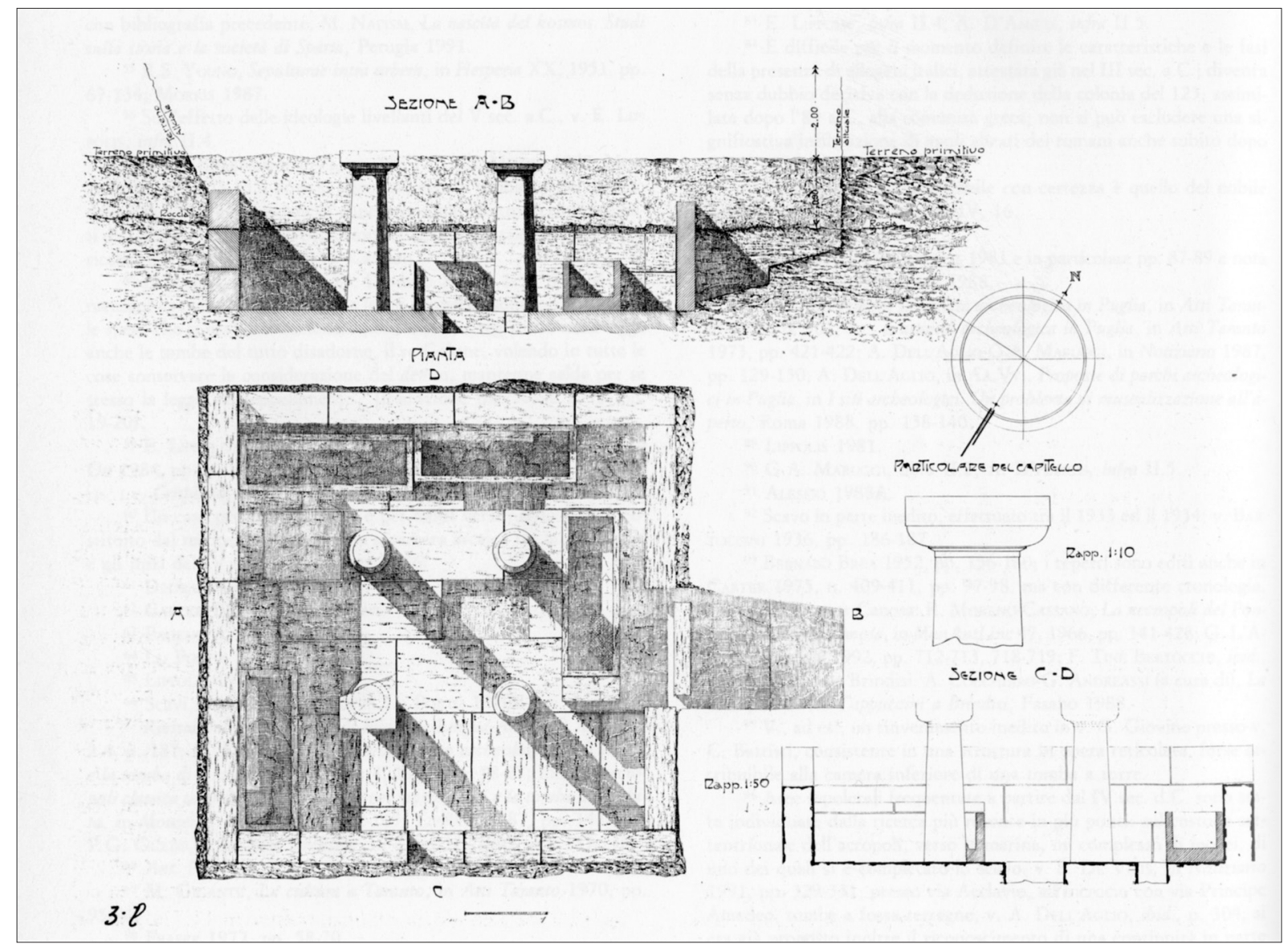

Fig. 5.24. Taras. Groundplan and reconstruction of an elite burial chamber (6th century BC); after Maruggi 1994.

sels). The pot containing the small body was usually a large impasto jar. ${ }^{85}$ In the indigenous settlements of the Archaic-Classical period, the dead were close to the living, just as during the preceding Iron Age. They were probably buried in the settlement area that was the intra-site territory of, or in any case the area closely linked with, the family or the clan to which the deceased belonged.

The differences between the contents of the elites tombs of the Greek urban centres and indigenous settlements were limited. The only major difference is that male burials in the non-Greek areas often contain weapons and armour. In this respect there was continuity between the Iron Age and the Archaic-Classical period. But the symbols stressing martial qualities changed. While during the Iron Age the sword was the most distinctive feature for the warrior elite, the graves of the indigenous elites of the 6th century BC often contained (parts of) Greek panoplies (fig. 5.26). Swords, spears and javelins can also be found, though not in large quantities. Whilst objects referring to warrior status disappeared from the graves in much of southeast Italy in the final quarter of the 6th century, the custom of depositing armour and weaponry into the graves persisted in northern Apulia and in upper Basilicata (e.g. Chiaromonte district, Melfi area) to well within the 5th century BC. ${ }^{86}$ The so-called

85 Corinthian A amphorae have also been used for this purpose. Hitherto amphorae used in this way, have been excavated only at 7th-century Siris (Berlingò 1986) and L'Incoronata (unpublished).
86 For a late 5th century tomb from Chiaromonte, see Bottini et al. 1993, 95-109; see also Lissi Caronna 1980 for a series of 5 th century tombs from Oppido Lucano. 


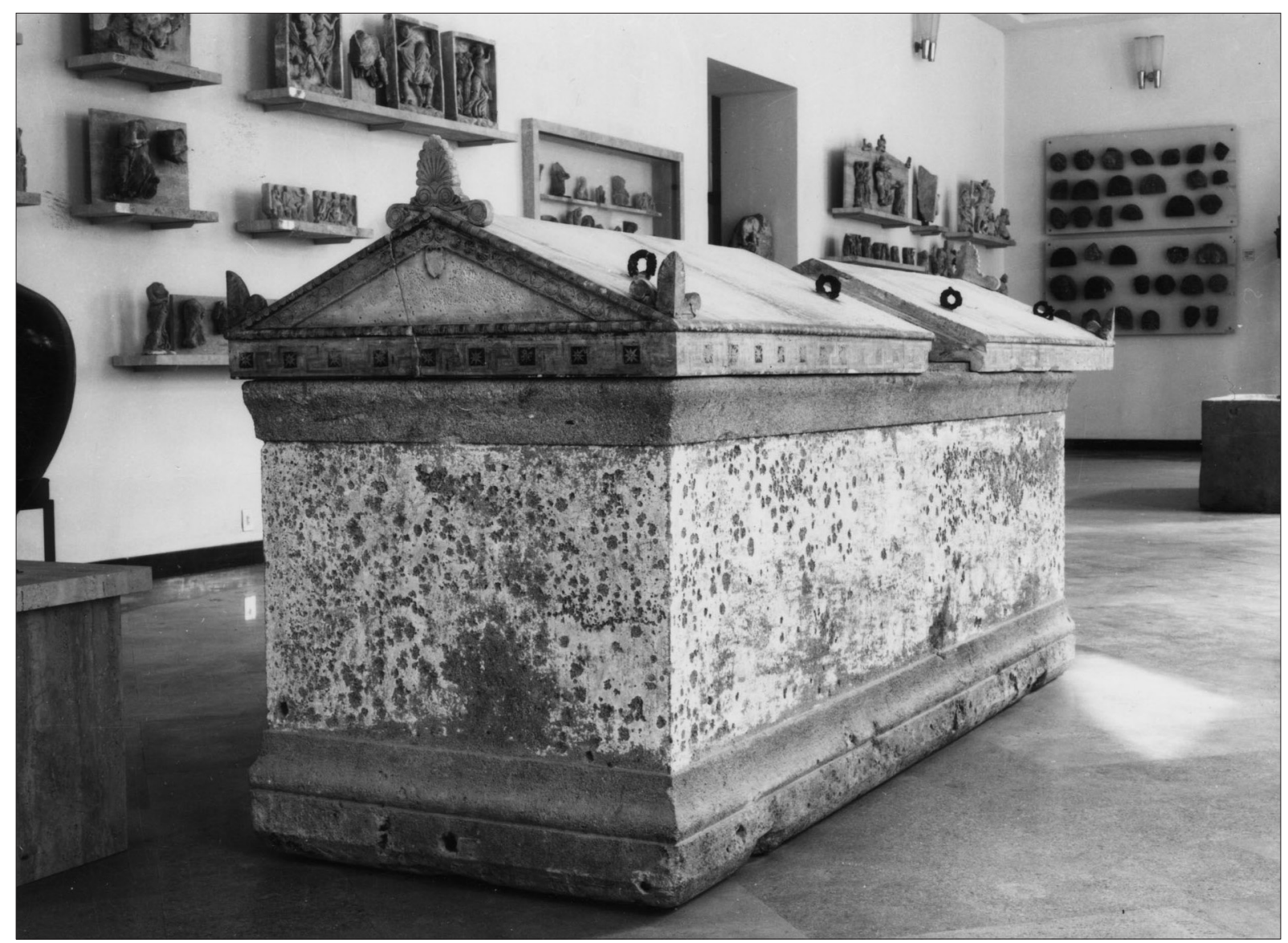

Fig. 5.25. Taras. Tomb of the Panathenaeic victor (5th century BC), Soprintendenza Taranto.

'Apulo-Corinthian' bronze helmets of the 5th century, having no holes for the eyes, demonstrate that warrior status was probably mainly expressed in the funerary sphere (fig. 5.27)

Whatever the differences, the graves of the Greek urban centres and the indigenous settlements of southeast Italy shared several features. Like the vast majority of the elite burials of the urban centres, the elite graves of the indigenous districts were large sarcophagus burials or cist tombs. Moreover, like those in the poleis they contained vessels pertaining to banqueting. Vessels referring to such activities are present in contexts of non-Greek areas during the early 6th century BC, ${ }^{87}$ but became especially frequent from the late 6th century onward. Among the banqueting objects are both bronze vessels and ceramic pots such as late-Corinthian and Attic black- and red-figured kraters, wine jugs of various types, bronze simpula, bronze hydriae and large, bronze basins (podanipteres). ${ }^{88}$ What is emphasized is feasting. The dead persons are provided with the accoutrements necessary for drinking wine and banqueting. In addition to these, the first indigenous tombs with objects (e.g. strigiles, alabastra) referring to the palaistra (or to paideia in general) can be observed during the 5th century BC..$^{89}$ Native elite representation closely followed the ways in which the Greek elites of southeast Italy presented themselves.

87 See Armento tomb A in Bottini et al. 1993, 61-69 (2nd quarter to middle of the 6th century BC).

88 The bronze vessels of Apulia have been collected by Tarditti (1996), for Attic kraters (pottery), see Mannino 2006.
89 See, for instance, Bottini et al. 1993, 95-109 (Chiaromonte - San Pasquale, tomb 227; late 5th century); Lo Porto 1994, 70-82 (Cavallino, tomb 2; earlier 5th century). 


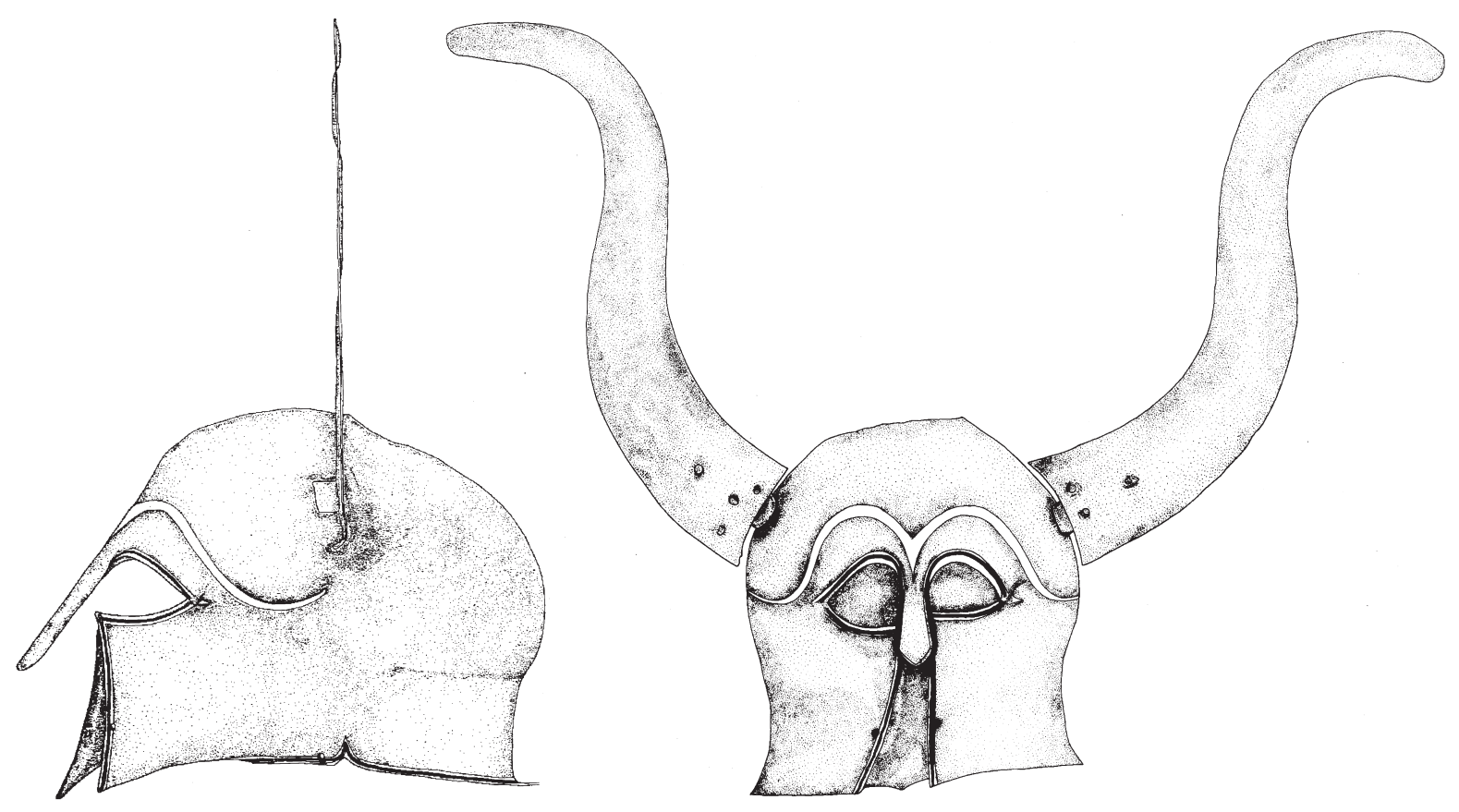

Fig. 5.26. Chiaromonte-Sotto La Croce tomb 170 (western Basilicata). Corinthian helmet (with local additions) from native elite grave, late 6th century BC; after Bottini 1993.

Generally speaking, the ideological aspects expressed in both Greek and indigenous elite tombs were very similar. Initially the indigenous elite tombs stressed both martiality and banqueting (6th century BC), whilst elite tombs of the Greek urban centres focused on banqueting only (c. 590/580480/470 BC). From about 480 BC the elite tombs of the Greek urban centres began to refer to both banqueting and paideia (palaistra), whilst the same combination of ideological features is found in most of the non-Greek districts from the late 5th century onward.

Elite graves were not confined to a few non-Greek settlements only. They occur in almost every settlements of southeast Italy. Therefore, they are likely to be indicative of elites of local importance. During the 5th century and the early 4th century BC this type of tombs continued to exist. It was, however, in the uplands of Basilicata that even more spectacular tombs made their appearance. They date between the late 6th and the middle of the 5th century BC. Their contents ooze power, opulence and wide-ranging interregional contacts. Only a handfull of these have been reported hitherto. The earliest 'royal' burial plot was discovered at Baragiano (north-Lucania) and dates to the late 6th/early 5th century. A second burial plot with nine graves has been found on a terrace on the flanks of the Serra di Vaglio mountain (Serra di Vaglio-Braida, first half 5th century) and two spectacular burials stem from the site of Pisciolo in the Melfi district in the northeastern part of Basilicata (mid 5th century). ${ }^{90}$

These unusual, extremely opulent burials have been interpreted as the graves of indigenous basileis ('kings') and may well be taken to have been the graves of paramount chiefs and their close relatives. These tombs do not only differ from local elite tombs by the sheer quantity of the finds. A seven

90 The Baragiano burials have been shown in the exhibition Principi ed eroi della Basilicata (Potenza 2009-2010); for the 'royal' tombs from Serra di Vaglio-Braida (central Basilicata), see Bottini / Setari 1995, 1996 and especially Bottini and Setari 2003. The nine Braida burials contained the remains of ten persons: six men, one woman and three children. For the Pisciolo tombs 43 and 48 (in the Melfi area), see Popoli anellenici, 120128, tombs 43 and 48; Adamesteanu 1974. 


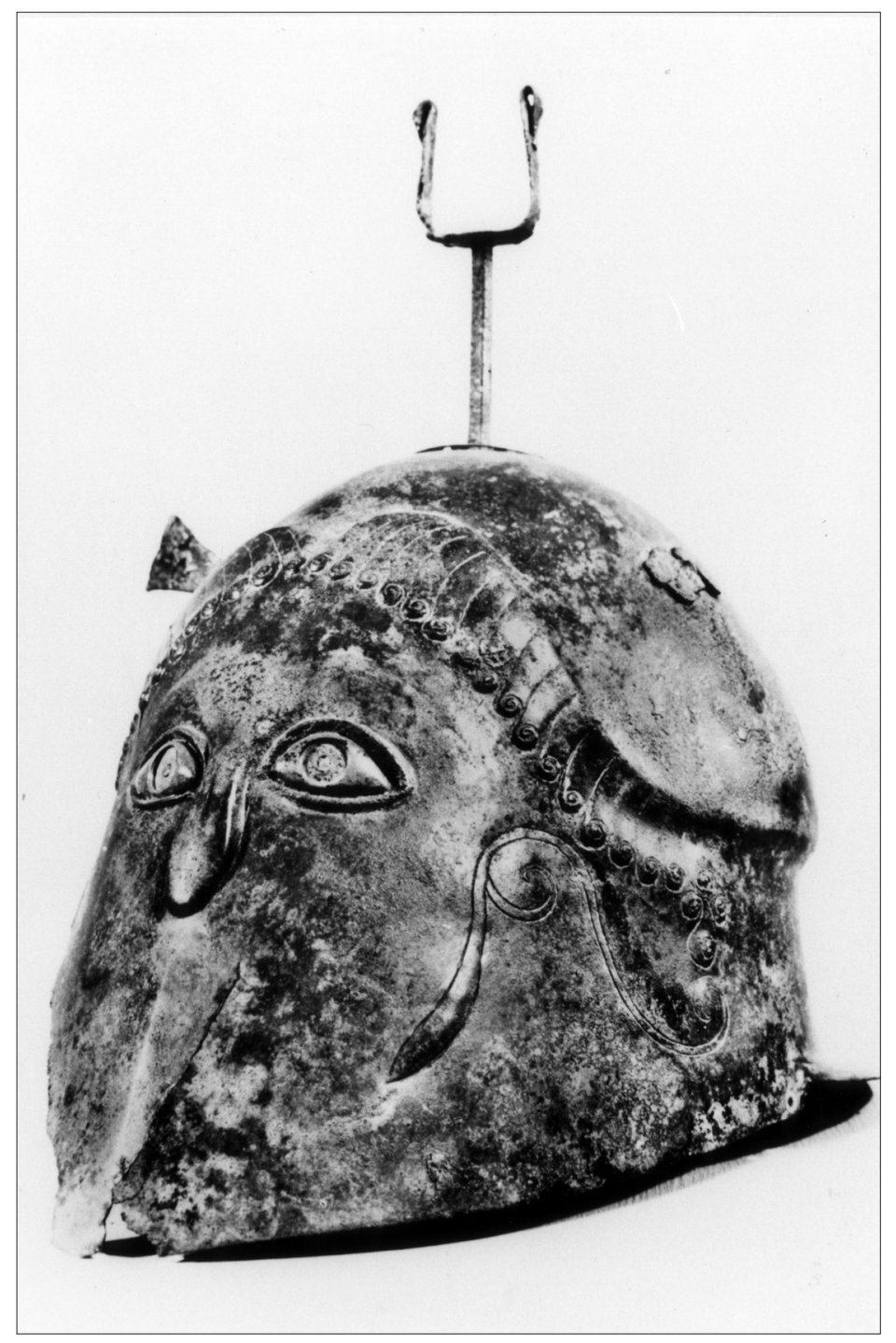

Fig. 5.27. 'Apulian' funerary helmet, 5th century BC. Bari, Museo Archeologico. Courtesy Bari Museum.

years old girl in the Braida cemetery was buried with a breathtaking display of gold and amber. Whilst finely decorated Attic pottery can be found in the local elite graves, these exceptional burials stand out because of the dazzling quantity and quality of the objects they contained: magnificent horse gear, fibulae of silver and gold, diadems and magnificently carved amber beads and pendants (fig. 5.28). Although part of the metal objects in these graves may be local or regional workmanship, there are also objects that were transported over large distances. At Pisciolo, for instance, there is a set of exquisite Etruscan bronzes.

These basileis burials also contain references to the use of chariots. One of the Pisciolo tombs contains a set of wheels, whilst a male burial of Serra di Vaglio has elaborately decorated bronze horse gear decorated in Greek style such as prometopidia ('headplates') and prosternopidia (breastplates) (fig. 5.28). ${ }^{91}$ Most of the objects found in these basileis-burials are unpractical for regular use. They are evidently ostentatious display and are likely to have functioned in ceremonies and rituals in which their owners were the protagonists. These incredibly opulent burials are completely unparalleled in the urban centres of southeast Italy. They testify to the presence of new, powerful leaders that ranked above the various local and cantonal chieftains and controlled vast territories of Lucania. Since the 'royal' burials of Baragiano, Serra di Vaglio and Melfi-Pisciolo are chronologically subsequent, this might suggest that supreme leadership shifted in the uplands of Lucania, if at least the above interpretation is correct. Perhaps these paramount chiefs/basileis were elected by their peers.

The princely graves of Melfi-Pisciolo, Serra di Vaglio-Braida and Baragiano are truly exceptional. The aristocrats buried there identified themselves as outstanding elite through their privileged access to exotic commodities such as gold, amber and pots decorated with figured scenes. On the basis of the funerary evidence, therefore, it is clear that the rise of powerful local elites, imposing local warlords

91 The tomb group of Serra di Vaglio-Braida is in the same area as the dining hall discussed in section 5.3. Tomb 101 contains the prometopidia and prosternopidia; the wheels have been found in Pisciolo tomb 43. In a fairly distant past a prometopidion and a prosternopidion have reportedly been found at Ruvo di Puglia in the central-Apulian Bari area (see Cassano 1997, 61, nos. 21-22). 

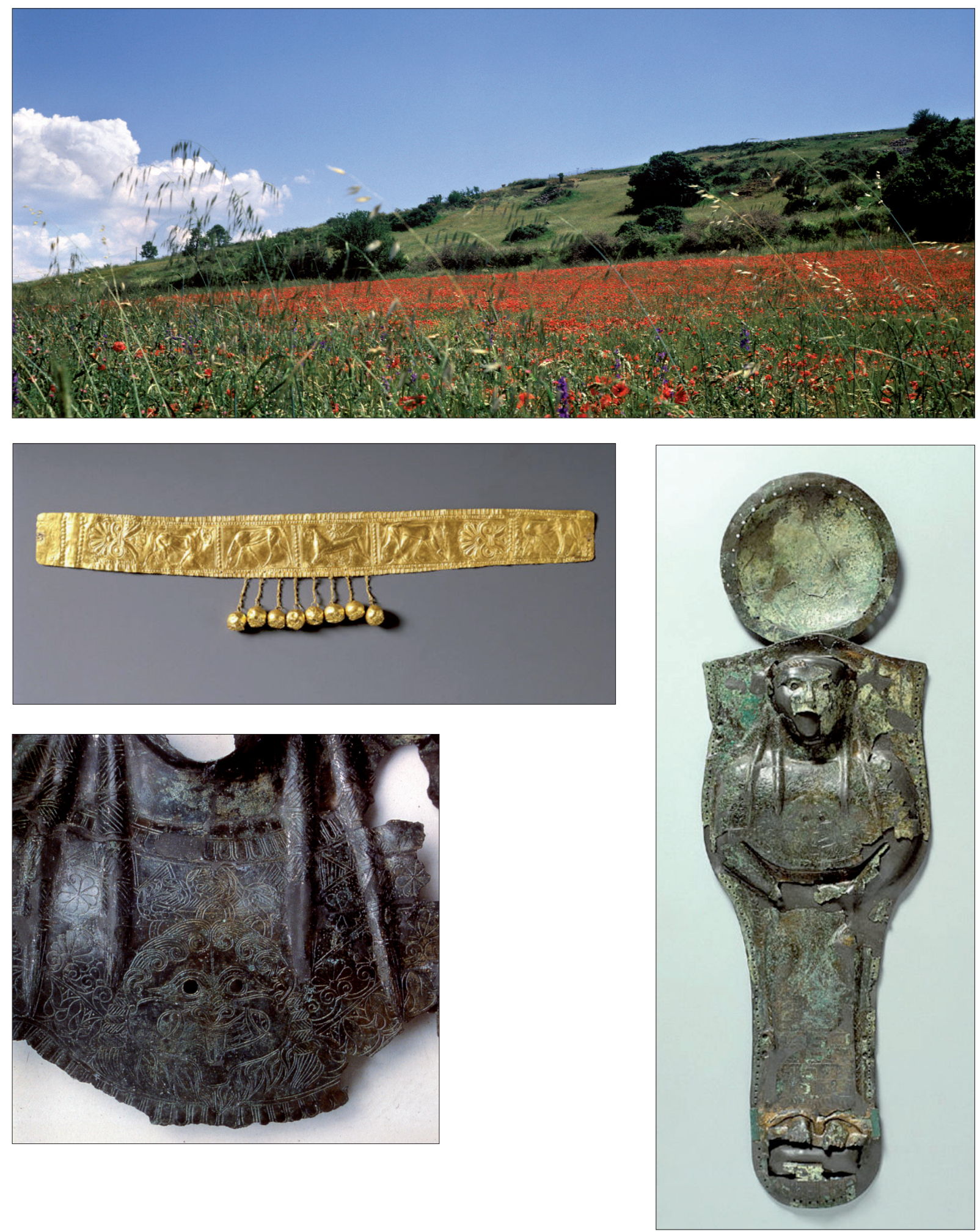

Fig. 5.28. Serra di Vaglio-Braida (upper Basilicata): site and objects from royal burials. Photos courtesy Soprintendenza Basilicata. 
and perhaps even regional elites was a widely diffused phenomenon in southern Italy. The evidence, moreover, does not come exclusively from the funerary evidence presented above. The ancient written sources too are quite explicit on this subject (see Chapter 5.7: Ancient written sources).

In the preceding chapter on the Iron Age we have encountered people living in the autochthonous communities of southeast Italy who held a special status. They manifested themselves in the elite burials of, for instance, Tursi-Sorigliano (8th century) and Canosa (7th century). They have been interpreted as the burials of powerful local elites. With the coming of the Archaic period outstanding graves of people of local importance continued to be made. Now they are found not only in the socalled 'native' territories, but also in the new urban settlements on the coast: the emerging poleis with their Greek identities. Before the middle of the 6th century a Greek elite had emerged in the Greek poleis. The distribution of elite family graves over the Taranto necropoleis shows that the settlement had several families of wealth and influence during the 6th and 5th centuries BC. Metapontion had comparable elite families. Together these made up the local aristocracy of the town. In their graves they present themselves as banqueteers and - from about the early 5th century onward - as cultured people with paideia by referring to the palaistra by means of strigiles and alabastra.

The interpretation of the 6th and 5th century indigenous elite burials is complicated. As for the graves of the 6th century BC their often martial character and their relative rareness (approximately one or two male burial per generation per settlement) indicates that they can possibly be read as the tombs of local warlords, perhaps leaders of local clans. These may have been persons who had achieved local prominence because of their lineage, their prowess and their heroic behaviour in raids and warfare. In the late 6th century BC banqueting equipment begins to supplement and replace the symbols of warrior status in the graves of non-Greek settlements. The earliest signs of this change are found in the districts close to the new poleis. This process continued during much of the 5th century BC when a spread of similar changes can be observed in districts further away from the Greek poleis. Armour, however, did not vanish completely from the burials in the tribal areas. Even during the 4th century BC great warrior chiefs could be buried with their cuirass, helmet and javelin (see chapter 6).

By the later 5th century BC objects referring to Greek paideia make their appearance in the burials of the areas outside the Greek towns. Again it happened first in the districts close to these poleis. These more recent elite graves, moreover, seem to be more numerous. In some cases, it seems, two or three (near-) contemporary clusters of elite graves can be found within the same settlement. This suggests that by this time each tribal settlement had various elite families. The selection of objects put into the graves, being so closely comparable to those of the Greek aristocrats of southeast Italy, suggest that these families together made up the local aristocracy of the non-Greek settlement.

A completely new phenomenon is the appearance of the spectacular 'royal' burials in the uplands of Basilicata. They date to between 510/500 and 450/440 and are unparalleled in other parts of southeast Italy. They suggest that something happened in the uplands of Basilicata that led to the appearance of men of decidedly regional importance. Since both the 'royal' burials of Serra di Vaglio and those of Pisciolo cover only one generation, they are probably not indicative of hereditary kingship. The persons buried in those graves are more likely to have been paramount chiefs who - perhaps starting as cantonal chiefs - came to control more or larger tribal groups. This could, for instance, have happened because of a combination of outside pressure, a charismatic personality and outstanding martial qualities. 


\section{$5 \cdot 5$ C H A N GES IN C R A F T}

The construction of the dispersed settlements consisting of huts or primitive houses of the 8 th and 7 th centuries BC did not require much specialist labour. The family group, for instance, was easily capable of constructing the fairly simple dwellings that are characteristic of that period. This observation holds good for both settlements exclusively inhabited by indigenous groups and settlements with mixed populations such as 7th-century Siris, Metapontion, L'Incoronata and L'Amastuola. Larger settlements may have had one or two potters and a blacksmith. In the Iron Age craft was limited to a few specialists only who are likely to have exerted their craft mainly on a part time basis.

The rise of urban and 'proto-urban' centres and the birth of the more or less complex societies that lived in these settlements, caused major changes in craft. The innovations can mostly be dated between the end of the 7th century and the middle of the 6th century. These occurred first and foremost in the sector of architecture. We have seen above that wattle-and-daub huts were replaced by tile-covered habitations of stone and mudbrick and that impressive fortifications were erected. The urban settlements, moreover, were adorned with large sacred and public buildings made of stone, timber and terracotta (tiles, revetments).

The numerous building activities that took place in quite a number of settlements of southeast Italy, had an enormous impact on the development of craft. They required a substantial working force and qualified artisans of various types. The extraction and working of tons of sandstone or limestone for the construction of fortifications, temples, sacella, houses and graves required the adoption of new skills on an unprecedented scale. Usually the quarries were within a short distance from the settlement, but archaic-classical Metapontion with its prestigious architecture was on alluvial soils and was forced to transport its building materials over distances of at least $40 \mathrm{~km}$. For the construction of temples and houses, timber and carpenter's abilities were needed in order to make the lintels and the stairs and to hew the beams that carried the roofs of these buildings. The production of terracotta tiles, simae, acroteria and antefixes that covered or decorated the roofs, required the presence of tile makers and artisans that had the abilities to produce large clay objects in moulds and were able to fire these objects in closed, well-controlled kilns. The men who quarried the stones, transported them and worked them, the persons who produced tiles and terracotta ornaments and the people who turned wood into beams and constructed the wooden parts of houses, shrines and temples were probably mostly full time specialists.

The products of some of these specialists were required only incidentally. These persons operated on a regional scale. This observation holds good for the terracotta revetments of prestigious buildings. The terracotta frieze of the Braida dining hall on the flanks of the Serra di Vaglio mountain, for instance, displays such a close similarity to terracotta revetments from the Metapontion territory that a Metapontine origin of the makers has been assumed, whereas the friezes of the Satriano anaktoron have grafitti suggesting a Tarantine origin. ${ }^{92}$ The terracotta revetments of Cavallino, made of decidedly local clays, have such close parallels at the island of Corfu, that the presence of Corfiote artisans in the non-Greek settlement has been hypothesized. Archaic capitals from Cavallino, Vaste and Ugento, all made in local limestone, again bear a strong likeness to capitals from Greek settlements across the Adriatic (e.g. Corcyra, Epidamos) and were probably also made by imported craftsmen who stayed in settlements with a non-Greek population on a temporary basis. ${ }^{93}$

92 The closest parallels are the revetments of sacellum $\mathrm{C}$ at Metapontion and the sacellum of the rural sanctuary of San Biagio alla Venella, 6 km from Metapontion; see
Lo Porto / Ranaldi 1990; for the revetments of Torre

di Satriano, see Capozzolo / Osanna 2009.

93 D’Andria 1977, and 1988. 
The 'import' of craftsmen, however, was probably a rather exceptional phenomenon. The Greek urban centres on the coast and several indigenous proto-urban settlements had their own carpenters, stonemasons and tile makers in order to construct the buildings. These persons, moreover, were not the only specialists in the new types of settlements of southeast Italy. Although the evidence for metal objects is thin (they were mostly recycled), ${ }^{94}$ people working iron and bronze must have been present in many settlements of southeast Italy. They produced the fibulae and metal vessels that have been found in burials (fig. 5.29). They also made numerous objects for daily use. Among these were objects used for the preparation of food (e.g. knives, graters), farming implements (e.g. hoes, picks, plows and ards) and hunting and war requisites (e.g. body armour, arrows, javelins, spears, swords), most of which are only rarely found in archaeological excavations. The weapons and body armour that turned up in the burials of the tribal areas suggest that both the Greek towns and the tribal settlements had specialists who produced such articles. ${ }^{95}$ The presence of other types of specialists such as tanners and leather workers in for instance the urban centres on the coast can only be surmised on the basis of ancient written sources on the Greek world of the 5th century BC: they do not appear in the archaeological record of southeast Italy for the Archaic-Classical period.

While metal objects are often recycled, pottery tends to survive. This phenomenon allows us to study the innovations that occurred in this particular craft. It will receive here an almost disproportionate attention, because it may be an example of what happened in other, less well documented sectors of craft. In ceramic production a major change took place in the 6th and 5th centuries BC. In the preceding chapter on the Iron Age we have seen that wheelmade ceramics with Greek technical and decorative features were produced in a limited number of settlements with a mixed population on the Gulf of Taranto. This happened from approximately the middle of the 7th century onward (Siris, L'Incoronata, Metaponto-Andrisani, L'Amastuola). Initially these 'new' Grecian ceramics were made alongside the traditional matt-painted wares that are characteristic of the autochthonous populations of southeast Italy. Both ceramic classes could be made and used within the same settlements. ${ }^{96}$ While the pottery produced in the emerging urban centres (Sybaris, Siris, Metapontion, Taras) was probably of exclusively Greek type from about the end of the 7th century BC, the traditional handmade mattpainted ceramics began to be replaced by the new wheelmade wares with Grecian decorative features in almost every part of southeast Italy from about 570/550 onward. Settlements with a completely or predominantly autochthonous population also started to use wheelmade wares decorated with horizontal bands.

These ceramics are known under various names, but the most appropriate term for this class is perhaps 'Wheelmade Plain and Banded wares'. ${ }^{97}$ The class had a long life and survived into the early 2nd century BC. ${ }^{98}$ The techniques and decorations introduced by newcomers with Greek roots (see table

94 The evidence concerning metal production in the Archaic-Classical period consists mostly of objects recovered from burials, such as fibulae and bronze vessels (Tarditti 1996).

95 For weapons and body armour found in Basilicata, see for instance, Bottini et al. 1993.

96 The coexistence of handmade matt-painted wares and wheelmade wares of Greek type during the later 7th century BC is documented for l'Incoronata (Carter 1993, 348; Denti 2010), Metaponto-Andrisani (De Siena 1986b), Siris (Berlingò 1986) and L'Amastuola (Burgers / Crielaard 2007, and 2011).
97 In Italian various terms are used to describe such wares. Since pottery decorated with horizontal bands was believed to be of Ionian origin, the term 'ceramica di tradizione ionica' has sometimes been used. The most common Italian terms at present are ceramica a fasce' or 'ceramica a bande'; here: Banded wares. Undecorated specimens of this wheelmade ware are mostly indicated as 'ceramica depurata' or 'ceramica figulina', here; 'Plain Wheelmade wares'.

98 Yntema 2001, 63-101 (Colonial-Greek and native Banded wares) and 237-277 (Plain wares of the preRoman period). 


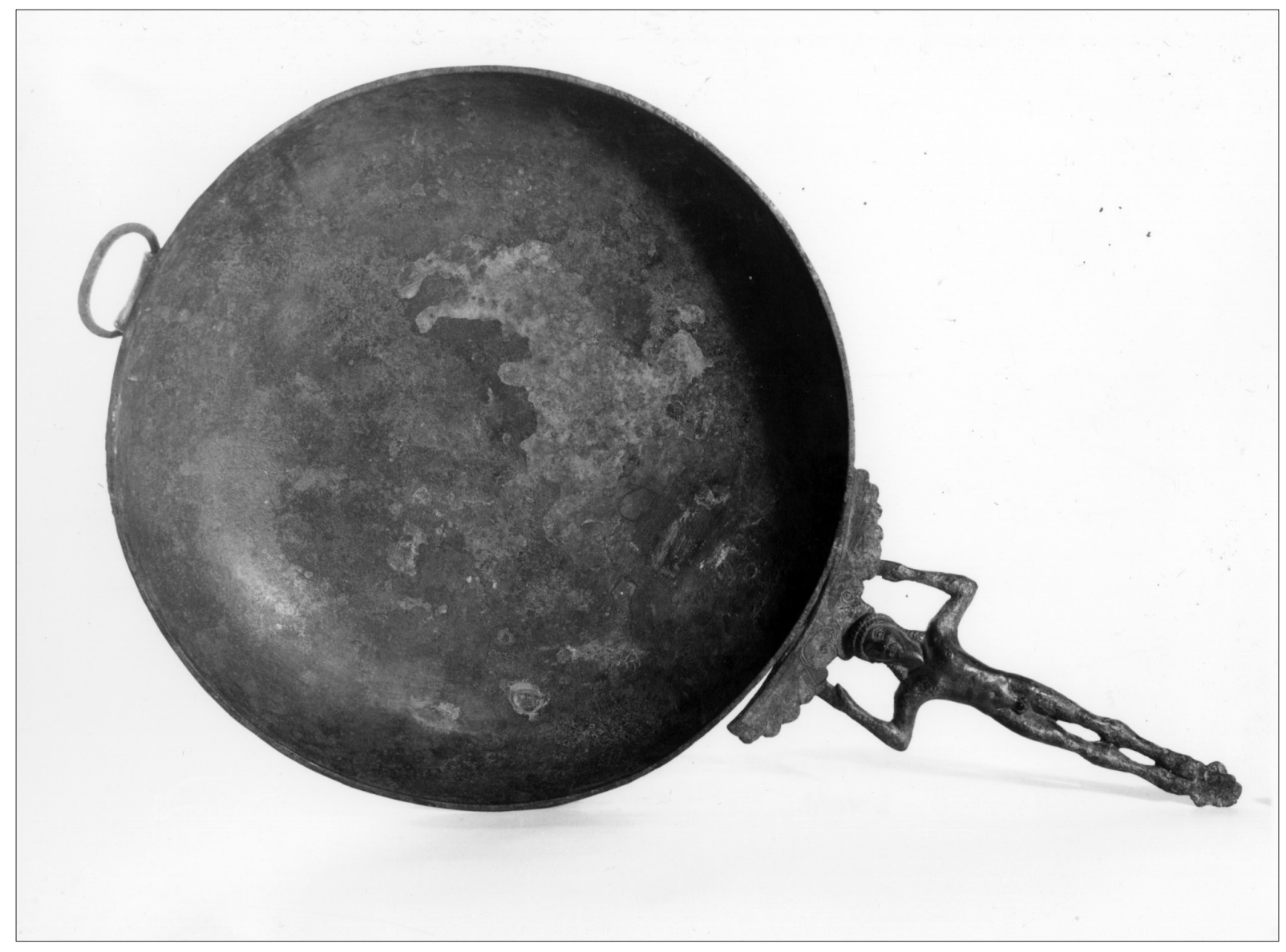

Fig. 5.29. Bronze pan with anthropomorphic handle from Canosa (north Apulia), 6th century BC. Courtesy Bari Museum.

5.2) were applied on an ever wider scale in ever larger parts of southeast Italy. The traditional handmade or slow-wheelmade, matt-painted pottery gradually disappeared from the world of the living. ${ }^{99}$

The main characteristics of the widely produced and widely diffused pottery class of Plain Wheelmade and Banded wares derived from Greek ceramic traditions. The pots were made of a light-coloured clay and thrown on the quick potter's wheel. ${ }^{100}$ They were fired at relatively high temperatures (c. $900-1000^{\circ} \mathrm{C}$ ). The forms were highly standardized and belong predominantly to the traditional Greek repertoire. The most common forms in the 6th and 5th centuries were the wine cups, bowls, jugs, hydriae, lekanai, one-handlers, stamnoid kraters, column kraters and storage jars (fig. 5.30a). In addition to these, wheelmade, banded versions of forms belonging to the originally autochthonous repertoires can also be found (fig. 5.30b). These hybrids (traditional indigenous shapes produced with a Greek pottery technology and decorated in the Greek way) were probably all made for funerary purposes.

The repertory of wheelmade forms is considerably more varied during the 6th and 5th centuries than that of the traditional Iron Age ceramics of southeast Italy and has more specific forms for more

99 Matt-Painted wares continued to be produced for some time for funerary purposes.

100 In settlements with a predominantly autochthonous population the tempering used for the clay body of the vessels is often the traditional tempering of the mattpainted vessels (crushed soft limestone and quartzite sand), whilst the urban centres with a Greek speaking population have a tempering of sand only. 

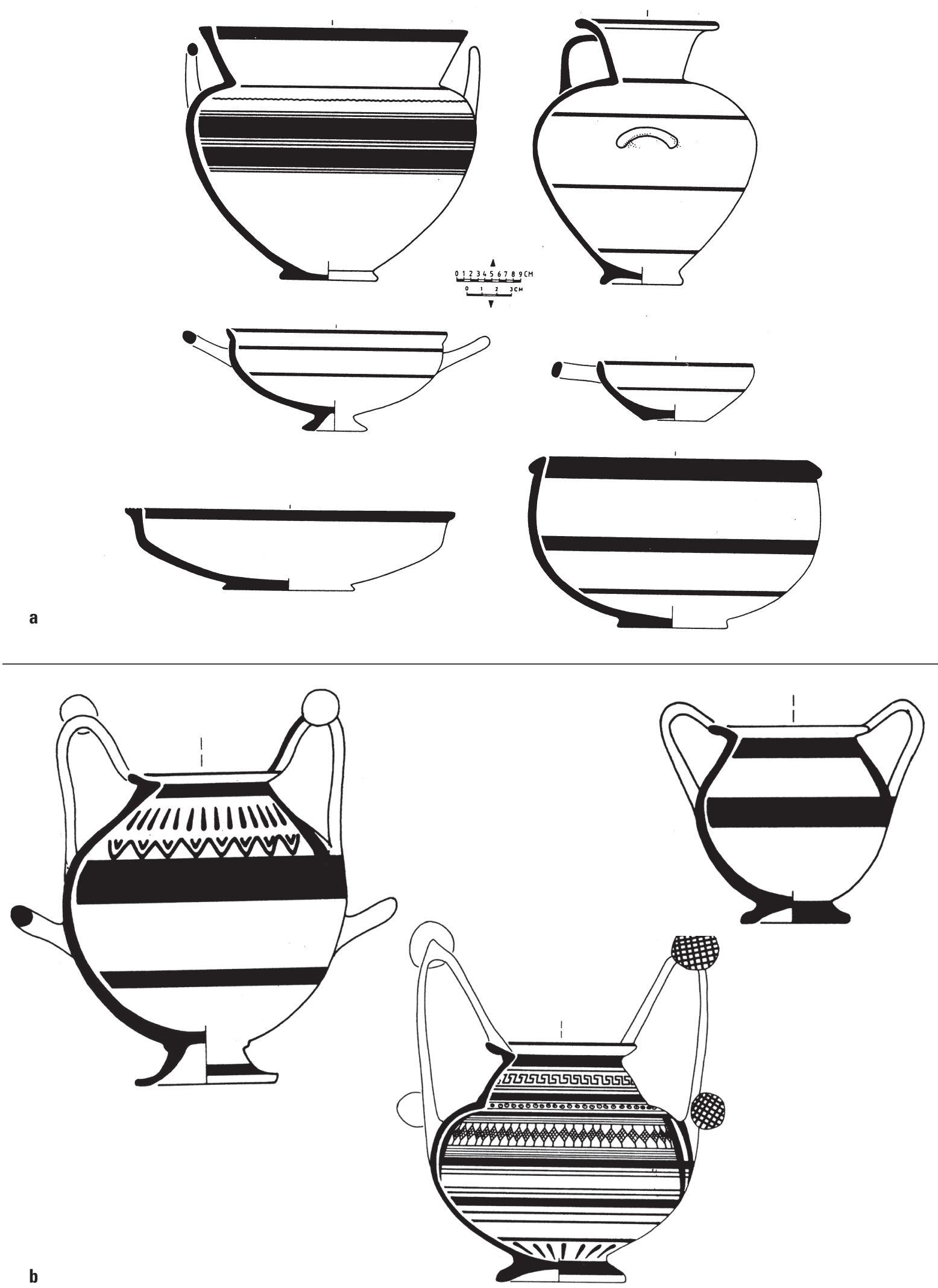

Fig. 5.30. Wheelmade pottery with vegetal and/or banded decoration from southeast Italy, 6th-5th centuries BC: (a) forms of the Greek repertoire; (b) forms of the indigenous repertoire (nestoris and kantharos from Satriano, Basilicata, and trozzella from Salento). 

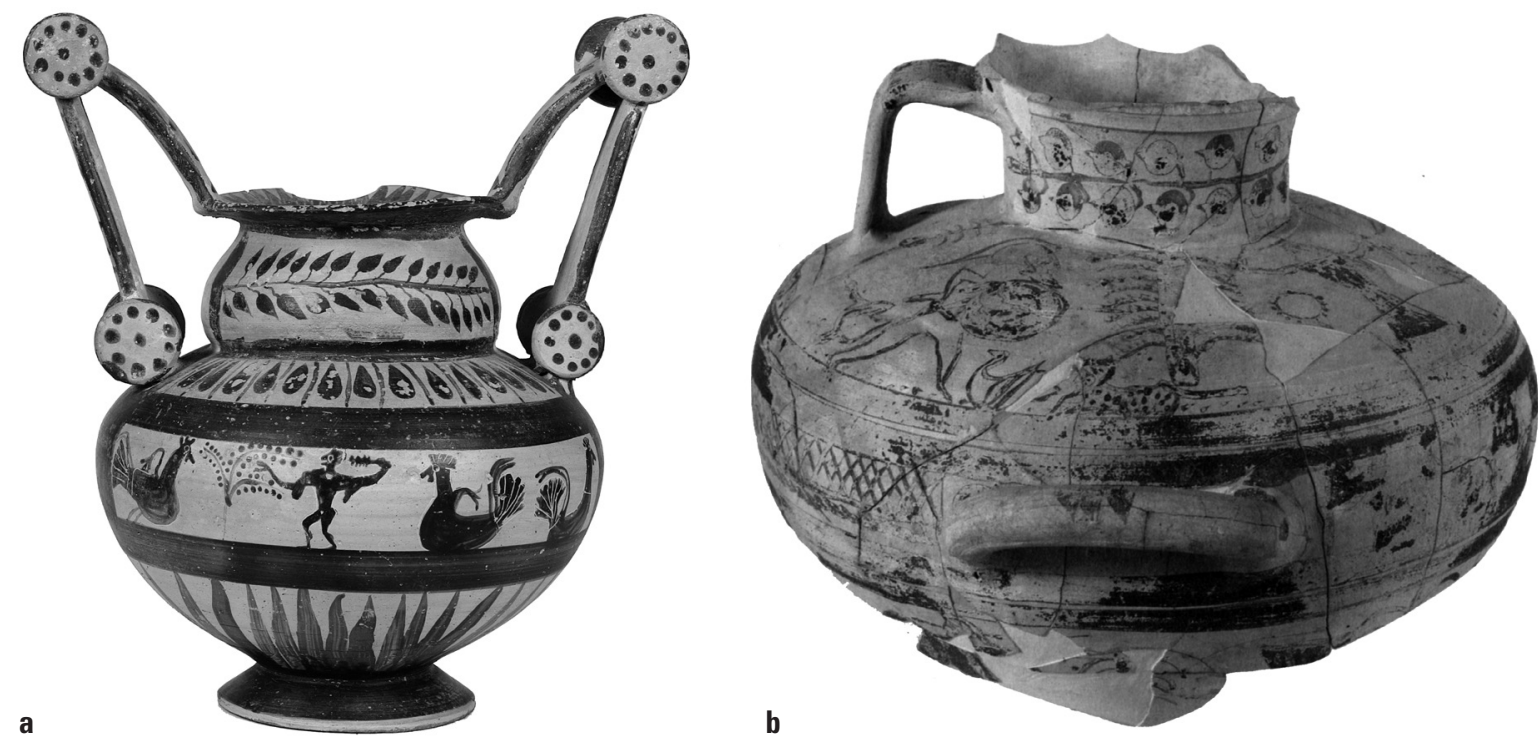

C

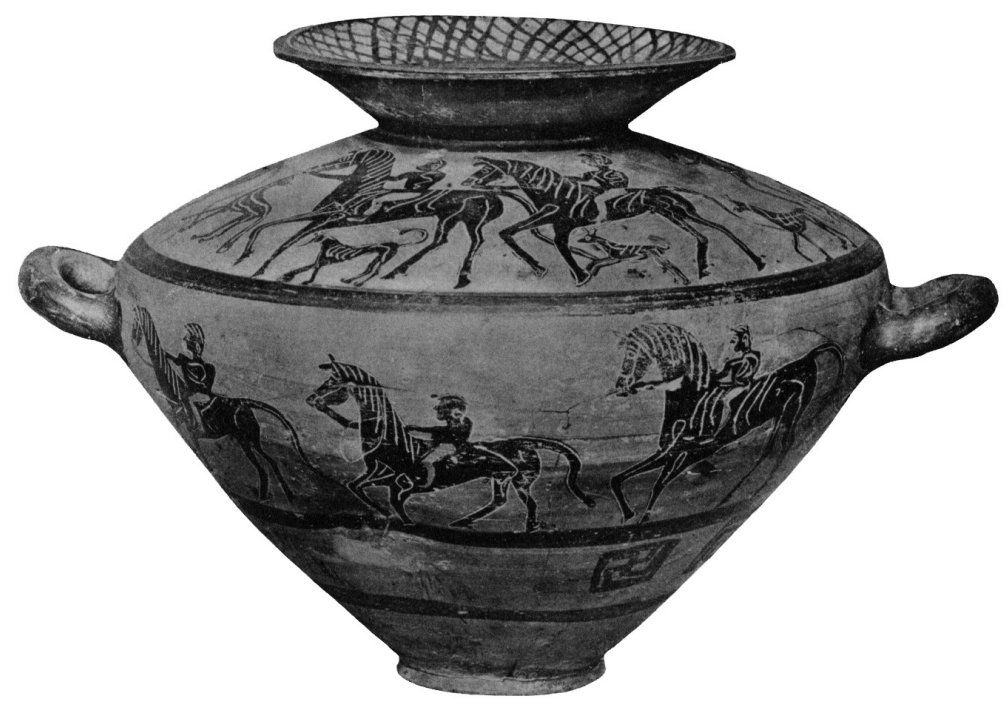

Fig. 5.31. (a) Trozzella from south-Apulia (courtesy Bari Museum); (b) fragmentary hydria (showing Odysseus and Circe), from Oria, sanctuary of Monte Papalucio (south Apulia), courtesy Lecce University; (c) funnel krater from Ruvo di Puglia (central Apulia); 1st half 5th century BC (after Mayer 1914).

specific purposes: kotylae and oinochoai for the consumption of wine, hydriae and jugs for water etc. The specimens with painted decoration mostly have horizontal bands only, but vegetal ornaments (e.g. palmettes, lotos buds and lotos flowers) derived from the secondary ornamentation of Greek decorated pottery (mostly Attic, early Lucanian and early Apulian RF) are also found. Such vegetal ornaments occur on pottery produced in non-Greek settlements from the 5th century BC onward. In the field of ornamentation too, there is a high degree of standardization. Specimens with figurative decoration such as quadrupeds and human figures are rare (5th century and later) and were probably exclusively made for funerary and votive contexts (fig. 5.31, 5.36). 


\begin{tabular}{|c|c|c|c|c|}
\hline & shaping techniques & firing & shapes & decoration \\
\hline $\begin{array}{l}\text { 8th-7th-century matt- } \\
\text { painted }\end{array}$ & $\begin{array}{l}\text { shaped by hand, hand- } \\
\text { activated turntable } \\
\text { and mould; surface } \\
\text { scraped with wooden } \\
\text { spatula; } \\
\text { manganese paint }\end{array}$ & $\begin{array}{l}\text { closed kiln; oxidizing } \\
\text { atmosphere; tempera- } \\
\text { ture c. } 700-8000 \mathrm{C}\end{array}$ & $\begin{array}{l}\text { exclusively forms with } \\
\text { pedigree in southern } \\
\text { Italy; repertory of } \\
\text { forms limited }\end{array}$ & $\begin{array}{l}\text { geometric type, partly } \\
\text { regional origins, partly } \\
\text { derived from Greek } \\
\text { (sub)-Geometric; hand- } \\
\text { painted; }\end{array}$ \\
\hline $\begin{array}{l}6 \text { th- } 5 \text { th century banded } \\
\text { wares }\end{array}$ & $\begin{array}{l}\text { quickly rotating potters } \\
\text { wheel, ferroid paint; } \\
\text { finish applied with } \\
\text { brush }\end{array}$ & $\begin{array}{l}\text { closed kiln; oxidizing } \\
\text { atmosphere; tempera- } \\
\text { ture c. } 900-10000 \mathrm{C}\end{array}$ & $\begin{array}{l}\text { predominantly forms } \\
\text { with Greek origins; } \\
\text { large repertory of } \\
\text { forms }\end{array}$ & $\begin{array}{l}\text { horizontal bands, } \\
\text { applied when pot } \\
\text { stood on turntable; } \\
\text { rarely vegetal orna- } \\
\text { ments }\end{array}$ \\
\hline
\end{tabular}

Table 5.2. Differences between the traditional Matt-Painted Wares of southern Italy (8th-7th century BC) and the Banded Wares produced all over southeast Italy in the 6th and 5th centuries BC.

The class of the Banded wares was not the only new type of pottery introduced in the ArchaicClassical period. Since Attic wares attained great popularity in southeast Italy in the late 6th and early 5th century BC, the potters of the Greek towns of southern Italy soon started to produce very similar wares. The earliest signs come from the Metapontion area. Here a small series of simply decorated black-figured pots and a much larger series of black gloss pots have been found (often in graves) which may easily be mistaken for Attic wares. They display a mix of Attic and local Metapontine shapes. ${ }^{101}$ The earliest specimens are likely to date to c. 480 BC. The Greek polis of Taras that produced various types of wares during the later 6th century (Banded wares, local somewhat Corinthianizing ceramics), ${ }^{102}$ may have started to make comparable 'Atticizing' wares at approximately the same times.

From the third quarter of the 5th century both towns added elaborately painted pottery to their repertoires. These are the so-called Lucanian (Metapontion) and Apulian (Taras) Red-Figured wares (fig. 5.32). In addition to a host of pottery vessels, terracotta statuettes were made in both Taras and Metapontion. The production of these objects is likely to have started in the 6th century BC. ${ }^{103}$ Thousands of these have been found in sanctuaries, predominantly in those of the Greek towns, but - albeit in much more limited quantities - in the sacred areas of the non-Greek world of southeast Italy as well. ${ }^{104}$ The rapid evolution of both the Greek and the indigenous societies of southeast Italy caused an enormous rise in the production and consumption of ceramic products. It also resulted in an increasing variety of ceramic supply. In addition to household ceramics (Banded wares, Plain wares, impasto containers), there were pots especially made for the graves (traditional native forms, ceramics with figurative decoration), pots and terracottas that served exclusively as votive offerings (miniature vessels, statuettes), antefixes and terracotta plaques that adorned buildings, and storage vessels especially produced for long distance transport ( fig. 5.33). ${ }^{105}$

The changes that took place in ceramic production resulted in a strong standardization of production methods, of the repertory of forms and of the decorative aspects of the pottery. In the areas inhabited

101 These early Metapontine Black Gloss Wares have a good lustrous black gloss and a mostly pinkish clay; for such wares, see Lo Porto 1973, passim; Lo Porto 1988/89, 332-337 (tombs from Montescaglioso) and Carter 1998a. For a short introduction into Metapontine Black Figure, see Yntema 2001, 123.

102 For such probably 6th-century Tarantine wares see Lo
Porto 1963 and 1964, and D'Andria et al. 1990, 262-

263 (Oria, Monte Papalucio sanctuary).

103 For early terracotta statuettes from Metapontion's chõra, see, for instance, Olbrich 1979 (San Biaggio alla Venella).

104 For archaic terracottas statuettes from Taranto sanctuaries, see Iacobone 1988.

105 cf. Sourisseau 2011. 

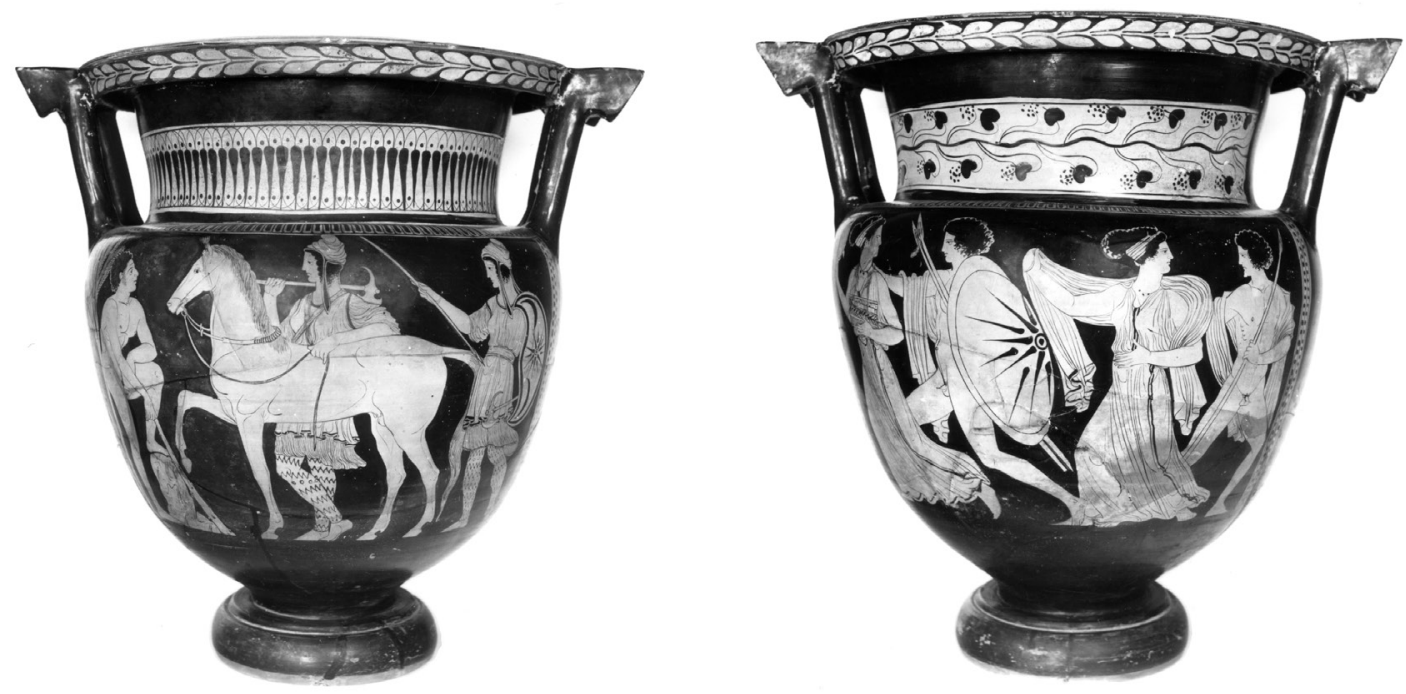

Fig. 5.32. Early Red-Figured pottery produced in southeast Italy: Lucanian Red-Figured column krater by the Big Head Painter c. 420/400 BC. Bari, Museo Archeologico (courtesy Bari Museum).

by the autochthonous populations these innovations started somewhere around 570/550. When exactly a particular district made this fairly sudden switch depended often on the contact situation with Greek polities and districts with non-Greek populations that had already adopted the 'new' ceramics. The Salento peninsula being close to Taras, Corcyra and Epidamnus, and the coastal area of Basilicata neighbouring on the chorai of Sybaris, Siris and Metapontion were the first areas to adopt these basically 'foreign' ways of producing pottery (c. 570/550). These areas were soon followed by the Bari district (c. 525/500) that is close to the northern Salento plain and came into regular contact with Greeks from about $530 \mathrm{BC} \cdot{ }^{106}$ In the uplands of Basilicata wheelmade wares with banded and vegetal decoration were introduced in the first half of the 5 th century BC. For the north-Apulian districts the moment of change is still uncertain: the archaeological record here predominantly consists of tombs in which traditional forms displaying traditional decoration and made in traditional techniques persisted much longer than in habitations. ${ }^{107}$ One may assume, however, that wheelmade pottery for everyday use was introduced here not before the later 5th century BC.

It has been stated above that ceramic production became increasingly standardized and that many potters of Archaic-Classical times usually were full time specialists. These changes are equally clear from the remains of pottery production found during various excavations. Pottery production sites of the 6th, 5th and early 4th centuries BC have been discovered at the Greek urban centres of Metapontion and Taras and the tribal centre of Oria on the Salento isthmus. At Metapontion a pottery production area was excavated at the northeastern outskirts of the town close to the city walls. ${ }^{108}$ Kilns, wasters, clay loaves and the remains of the workshops themselves were found here. The wasters suggest

106 From c. 530 BC Greeks started to penetrate the central and northern Adriatic: cf. the earliest phase of the emporia of Spina and Adria near the mouth of the river Po.

107 The tombs of Lavello in the Ofanto district suggest that Banded wares were known here by the late 5 th century BC (see Giorgi et al. 1988). In the tombs of the Tavoliere site of Ordona wheelmade ceramics with banded and vegetal decoration make their appearance in tombs of the earlier 4th century BC (Iker 1986). In both districts, however, (but especially at Canosa in the Ofanto district) traditional forms persisted to well into the 3rd century BC.

108 D’Andria 1975, Cracolici 2001. 


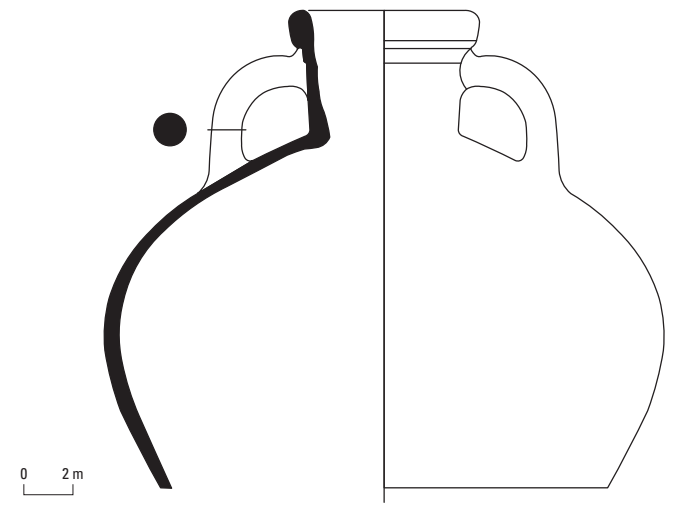

Fig. 5.33. Transport amphora produced in the Sybaris area (the so-called Corinthian B amphora); 6th century BC; from Sybaris. After Mater 2005, 247.

that ceramics of various classes were produced in this Metapontion kerameikos in the late 6th/early 5 th and again in the early 4th century BC. ${ }^{109}$ The pottery production units discovered at Taras date to the late(r) 5th century BC. ${ }^{110}$ Their location is comparable to that in Metapontion: they are on the eastern fringes of the town area, close to the

city walls. The remains of ceramic production at Taranto consist of wasters, kilns and workshop structures (fig. 5.34). These are indicative of all year round serial production with highly standardized output. From the tribal centre of Oria in the Salento peninsula kiln structures and ceramic wasters have been reported from a location at the northern fringes of the settlement area. ${ }^{111}$ They date to the late 6th and early 5th centuries BC and produced Wheelmade Plain and Banded wares (see fig. 5.30a). ${ }^{112}$

Another new feature that can be derived from the excavations of production areas was the increased complexity of pottery production. The Iron Age potter had no special working areas except for his kiln; he made his pots alone or with only one single assistant. The potters working in the 6th and 5th centuries, however, had roofed workshops with decanting basins and drying sheds and all. In these workshops groups of three to five craftsmen cooperated (e.g. evidence from Taras). The data from the early 4th-century Metapontion kiln site indicates that there was a very distinct labour division within these groups. ${ }^{113}$ The shaping, the painting and the firing of the ceramics were probably mostly done by different persons: they were specialists within their specialization.

In the areas outside the new Greek polities on the Gulf of Taranto the traditional wares were not completely replaced by Greek-type ceramics. During both the 5th and the first half of the 4th century $\mathrm{BC}$ the large impasto jars - often believed to have been characteristic of the Iron Age - continued to be made and used for storage purposes (see fig. 4.25b). ${ }^{114}$ In Basilicata they were still used for enchytrismos burials during the 5 th century. ${ }^{115}$ Other ceramic survivors were the matt-painted wares. These coex-

109 The late 6th century kilns produced Wheelmade Banded and Plain wares, the early 4th-century kilns made Lucanian Red-Figured (Creusa-Anabates group), Wheelmade Banded and Plain Wares, Black Gloss wares and terracottas.

110 Dell'Aglio 1996.

111 Maruggi 1993.

112 The Oria kilns of the late 6th/early 5th century BC are in the same area as the early 7 th-century kiln that produced impasto pottery and Matt-Painted wares (see chapter 4.6) and the 2nd/early 1st century BC kiln producing Apulian Grey Gloss (see VII.4).

113 The fingerprints on the misfired ceramics from the Anabates-Creusa workshop (D'Andria 1975) have been analysed by the Italian carabinieri. On one single pot fingerprints of three to four different people can be found which participated in the production process of the pots before these were fired. The throwing of the pot on the quick potter's wheel, for instance, was done by one person whilst the handles were attached by a second person (D’Andria 1997; Cracolici 2001 and 2003).

114 Impasto jars from 5th- and early 4th-century contexts are hardly different from the same jars in Iron Age or 6th-century contexts. In the Salento district, for instance, the former are fired at slightly higher temperatures and contain more limited quantities of manganese particles and crushed limestone particles than their Iron Age predecessors.

115 See, for instance, Holloway 1970, figs. 130, 132, 134, 136, 137 (all from Satriano); Lissi Caronna 1972, 515 (Oppido Lucano); Lo Porto 1973, pl. LXII-LXIV (all from Matera area). 

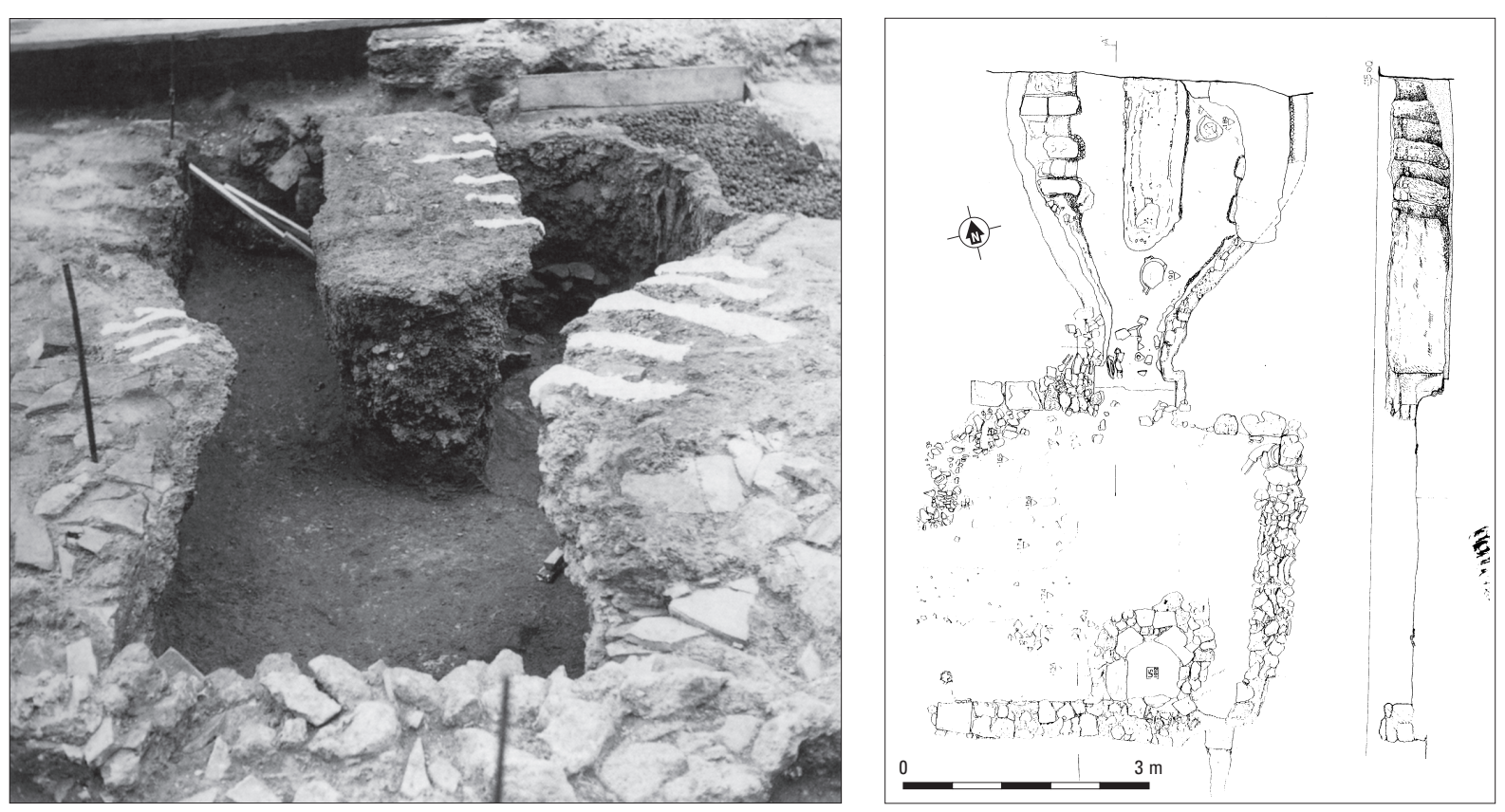

Fig. 5.34. Taranto (south Apulia): pottery production site and kiln of Via Leonida (5th-3rd entury (after Mater 2005, figs. 15-16).

isted with the new ceramic classes in Salento during the 6th and part of the 5th century BC, whilst in northern Apulia matt-painted pots were made as late as the early Hellenistic period. ${ }^{116}$ These traditional pots were no longer produced for daily use, but were especially produced for funerary purposes. They continued to be deposited in the burials in the indigenous districts (fig. 5.35). ${ }^{117}$

In this situation of coexistence between traditional pottery and new ceramic classes, the borders between these were often crossed. Hybrids showing a traditional native form with Grecian ornaments (fig. 5.31a) or basically Greek forms decorated in a native manner (fig. 5.36) occur in many districts, but exclusively in those that were outside the territories of the new Greek poleis on the Gulf of Taranto. From the 6th century BC onward the ceramics of these urban centres that proclaimed a Greek identity, were completely Greek in both style and production process.

What happened in the field of craft from the 6th century BC onward was almost as astonishing as the changes in settlement forms and settlement outfit. While there was only a very limited number of artisans in the Iron Age societies of southeast Italy, a very rapid increase can be observed in both the numbers and types of specialized craftsmen during the 6th century BC. From this time onward there were not only more specialized artisans, there was also a much greater variety of specialized artisans in southeast Italy producing a much larger range of objects. These specialists, moreover, were no parttimers as some of the Iron Age craftsmen of southeast Italy. They spent many if not all of their working hours in exercising their profession.

Another drastic change took place in the social context in which the artisan operated. The Iron Age potter, for instance, being probably both a part time farmer and a part time potter, was part of a family group within the local tribal society. By the 6th century BC, however, he was definitely an artisan. His status might have depended from his place of residence. In the proto-urban settlements

116 Yntema 1990, 272-286.
117 Especially in the graves of the women of Salento. 

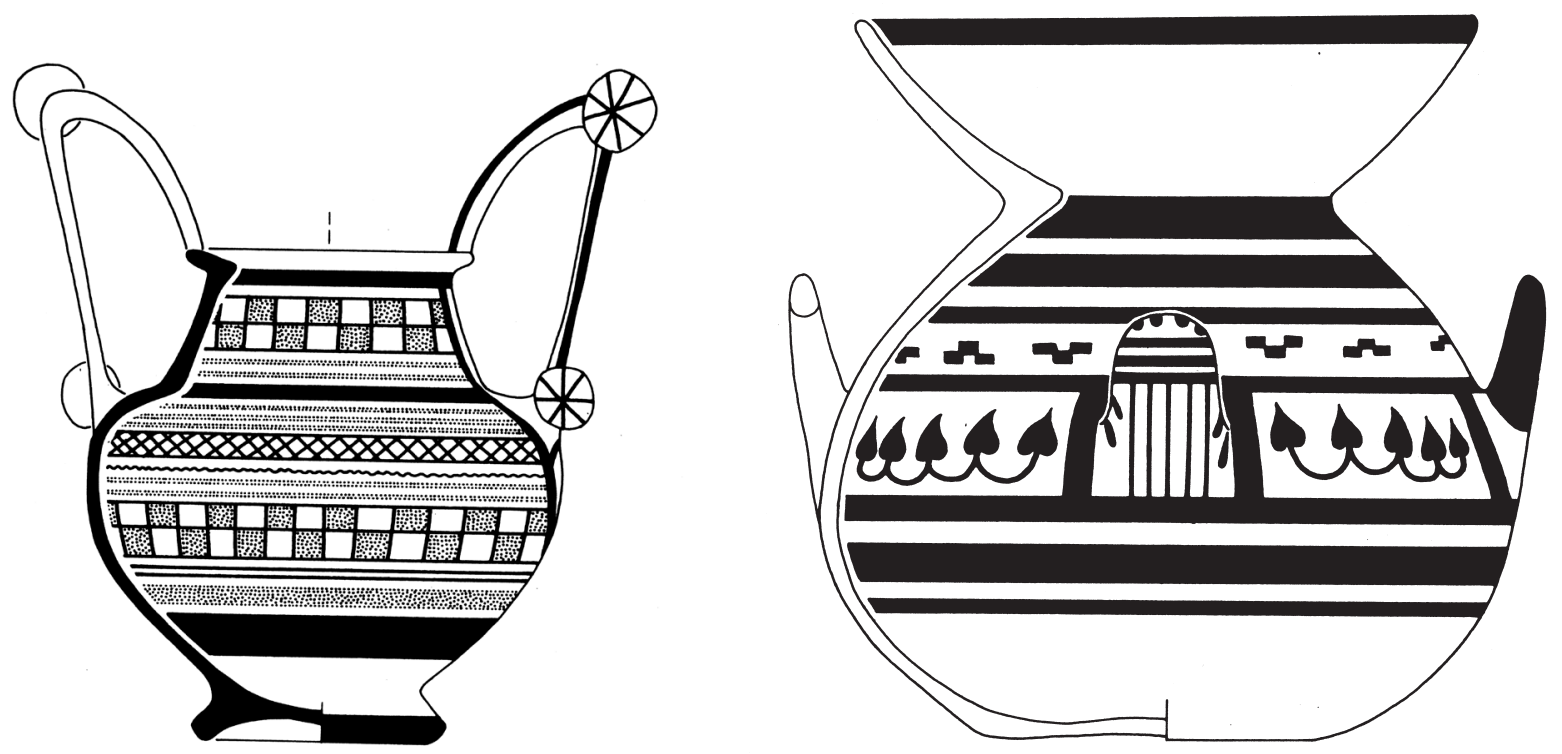

Fig. 5.35. Funerary wares with traditional indigenous forms: (a) wheelmade trozzella from Rudiae (south-Apulia), c. 450 BC; (b) handmade funnel krater from Canosa (north Apulia), c. 375/350 BC.

outside the coastal strip on the Gulf of Taranto he continued to be part of a tribal world: he might, for instance have belonged to the group of persons that depended on the local chieftain or the leading family of a local clan we have met in the passage on elite burials. But in the urban centres on the coast with their strongly mixed populations and their substantial groups of newcomers pottery production may have been more or less free enterprise.

Yet another innovation of the Archaic-Classical period was the greater complexity within particular sectors of craft. Potters, for instance, worked in small groups with a strict labour division. The evidence concerning pottery production shows that there were specialists within specializations. Similar sub-specializations are likely to have existed in the building sector, where the stonemason, the carpenter and the tile maker were different people. In some settlements the blacksmith making iron plough shoes, picks and shovels may have left the activity of making bronze fibulae, clasps and fittings of caskets and chests to a colleague who specialized in finer metal works, whilst the magnificent jewelry of southeast Italy was certainly made by specialist goldsmiths. ${ }^{118}$

The specialization in craft resulted in increased standardization of an increasingly large and varied artefactual output from the 6th century BC onward. This standardization did not only concern the quality, but also the forms and decorations of the artifacts. This process occurred in both the tribal areas and the Greek towns, but was decidedly more marked in the latter. ${ }^{119}$ The indications suggesting this development are patently clear in the ceramics, but what remains of bronze objects and the buildings suggest that standardization and serial production were indeed wide- spread phenomena in southeast Italy from the 6th century BC onward. Craft was no longer the domain of household production and part-timers, but was a full-blown specialist activity. These innovations in craft also had social implications. Whilst the craftsmen may have constituted new social groups in the Greek

118 For Archaic-Classical jewellery from southeast Italy, see Guzzo 1972 and 1993, and De Juliis 1990.

119 In the poleis, for instance, the production of ceramics was more varied. As for the ceramics, their potters/ coroplasts produced Black Gloss wares (from before the middle of the 5th century BC; in indigenous settlements probably not before the later 4th century BC), amphorae (Corinthian B) and an incredible host of terracotta statuettes. 

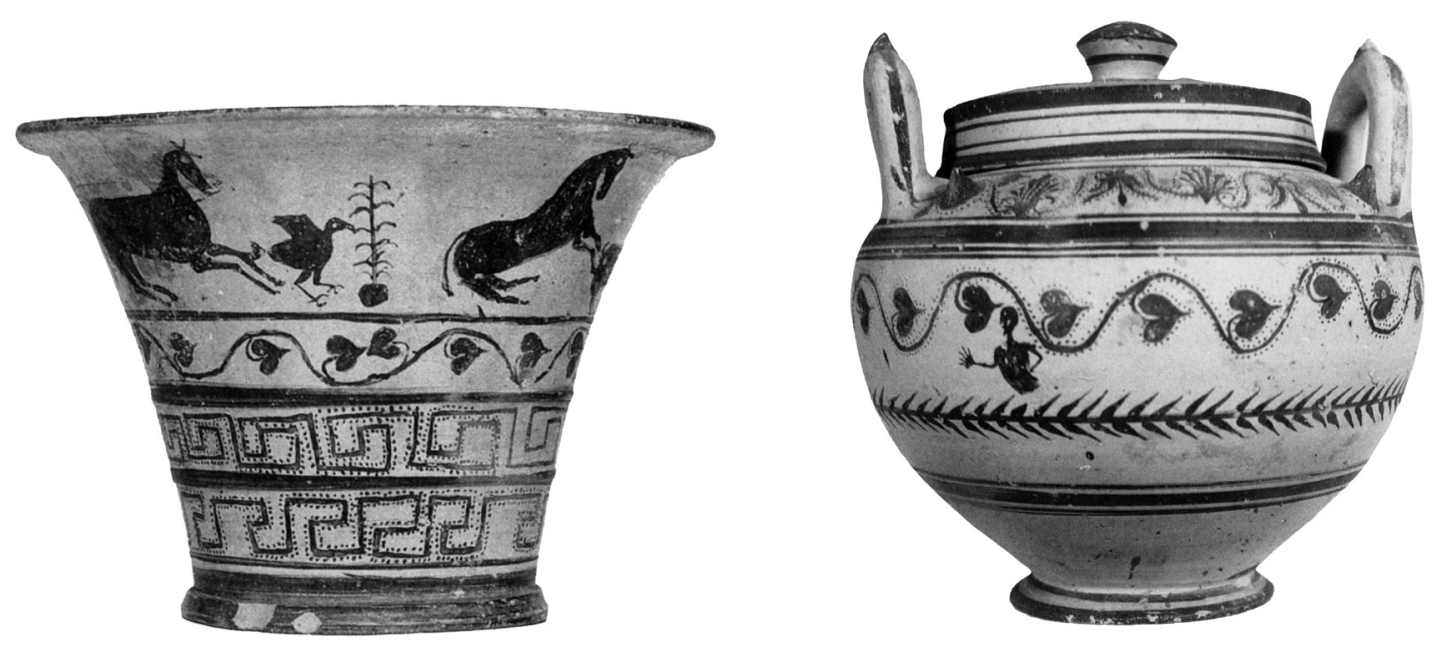

Fig. 5.36. Greek forms with 'native' decoration: kalathos and stamnos from central Apulia, mid 5th century BC. Photo Bari Museum.

speaking urban centres of Sybaris, Siris, Metapontion and Taras, they must have had a place within the kinship structure of the more complex tribal systems that prevailed in those districts of southeast Italy where the Oscan and Messapic languages were dominant.

\subsection{ECONOMY, INTERRELATIONS A N L ONG DISTANCE C O N T A C T S}

In ancient societies agriculture and stock raising are invariably the bases of the economy. Trade and exchange, though intensely studied by archaeologists and historians alike, played a decidedly minor role. Archaic-Classical southeast Italy was certainly no exception to this rule. There is a considerable body of information on barter, trade and exchange for this period. However, bio-archaeological data such as pollen cores, plant remains and animal bones have been collected and studied on only a fairly limited scale. ${ }^{120}$ The very limited data suggest that, whereas the Greek states set the first steps on the path of surplus production, the tribal aereas continued to focus on subsistance production. ${ }^{121}$

The artefactual evidence makes it patently clear that direct and indirect contact with areas outside southeast Italy increased enormously from the 6th century BC onward. Part of this intensification must be ascribed to the four new urban centres which saw themselves as Greek poleis. The tracers of these intensive contacts are the late-Corinthian pots and the Attic black and red-figured wares. These are found in large quantities in graves and sanctuaries of both the poleis and the non-Greek districts.

The contacts between the poleis and the original Greek core areas in the central and southern Aegean were not exclusively economic in character. The official link between the new urban centres in southern Italy and the Old World of Aegean Greece was the foundation story. Sybaris, Siris, Metapontion and Taras were all apoikíai ('aways from home' or 'aways from the oikos') and home was somewhere in the southern Balkans or the Aegean. In the historical-archaeological jargon these new

120 It should be noted that the acidity of the limestone soils that are found in large parts of southeat Italy do not favour the preservation of pollen.
121 Veenman 2002, 82-84 (bone samples from Valesio and Cavallino di Lecce) 
settlements of migrants are mostly indicated with the unfortunate term 'colonies'. ${ }^{122}$ The foundation stories of many apoikíai appear to display very similar narrative schemes. They tell us about tensions and unpleasantness in a settlement in the Greek core area, the departure of a group of people from the core area under the guidance of the oikistes (official founder, often after consultation of the oracle of Delphi in order to obtain divine sanction), the actual foundation of a new settlement (ktisis) in the new, non-Greek world and the often bitter conflicts with autochthonous populations.

The settlement in the old world from which the group started, is generally indicated as the metropolis (mother city). The inhabitants of Sybaris and Metapontion believed that they stemmed from the northern Peloponnesus (ancient Achaea) and therefore professed to be of Achaean origin. The people of Siris believed to have come from Colophon in Asia Minor and saw themselves as Ionians, whilst Taras' origo myth - following closely the narrative scheme detected by Carol Dougherty ${ }^{123}$ - said that the settlement was founded by a group that had departed from Peloponnesian Sparta.

There is good reason to believe that these foundation stories are certainly not more or less reliable, historical accounts about what happened in the 8th or 7th centuries when the settlements were supposedly founded. There are enormous discrepancies between the archaeological data and the information supplied by these written sources on the earliest phase of these settlements. ${ }^{124}$ The foundation stories basically reflect 6th- or 5th-century BC situations and can, therefore, be considered as the origo myths of the apoikiai. These supplied the population of the four Greek poleis with their origins and were among the elements that forged the strange hotchpotch consisting of various types of Greeks and Italians populating these settlements, into a new community. The people who belonged to this community shared the same past and the same rites and were proud of the magnificent religious and public buildings that adorned the new settlement. The foundation stories, therefore, played a vital role in the formation of local identities.

The foundation stories performed yet another role. They linked the new settlement in an originally non-Greek world with the metropolis in the old world of Aegean Greece. They made it a part of the metropolis's highly respected past and associated the new polis in Great Greece with the venerated traditions of ancient Greece. The oikist cult was one of the links between both worlds. The physical remains of the oikist cult of the polis of Metapontion, however, allegedly founded in the late 8th or early 7th century, appear to date to the 6th century BC. ${ }^{125}$ The foundation stories expressing 6th- or 5th-century situations may, therefore, well be good examples of reshaped or invented history that was meaningful to the 6th- or 5th-century present of the new urban centres. ${ }^{126}$ The presence of identical cults in both metropolis and apoikía was another important element in the mental ties that existed between Great Greece and Aegean Greece: they stressed the religious link between the old world and the new world of the apoikiai. ${ }^{127}$

122 The term 'colonies' for Greek settlements in originally non-Greek areas is unfortunate, because the same term is used for Roman settlements that were founded in a different way and with vastly different purposes. The same term is, of course, also applied to the West- and South-European dominance over large parts of Africa, Asia, America and Australia in pre-modern and modern times which differs vastly from the Greek diaspora.

123 Dougherty 1993.

124 These discrepancies are not only found in the dating of the ktisis, but mainly in the general atmosphere emanating from both types of sources: (1) the limited numbers of Greeks in the archaeological record against the much larger numbers suggested by the ancient written sources ; (2) the aims of the migrant Greeks (traders, artisans, mercenaries in the archaeological record against mainly farmers intent on founding a new society in the written sources); (3) the coexistence of Greeks and natives in the archaeological record against the strongly antithetic situation involving war, rape, sacrilege and mass murder in the written sources; for ample discussion on these aspects, see Yntema 2000 and 2011.

125 De Juliis 2001.

126 Yntema 2000 and 2011.

127 Cf. cults of Apollo Hiacynthios and the Dioskouroi in both Sparta and Taras. 
The four urban centres on the Gulf of Taranto of which the inhabitants labeled themselves as Greeks, constituted four independent polities and acted in this way. They had no lasting alliances with each other or with other apoikíai of southern Italy. Their real or alleged Greek backgrounds, their more or less Greek ways of life and Grecian set of values was no strong cohesive. It did not result in identities shared by all the poleis of Megale Hellas. At some point of their history they appear to have called themselves 'Italiotai'. But it is unknown when exactly this name was invented. ${ }^{128}$ It was possibly the result of Lucanian 5th and 4th pressure that gave them a feeling of shared interest that resulted in this artificially created, and unenthusiastically shared label. In fact, the only rather loose tie that bound together the towns of Great Greece created in southern Italy was a common religious focus. The 'supra-national' sanctuary at Cape Lacinia near Kroton (present-day Calabria) was the place where the members of the so-called Italiote league used to meet. The new Great Greece of southern Italy, therefore, was a close copy of Old Greece and demonstrated the same lack of political coherence, notwithstanding the presence of sometimes powerful indigenous polities on its doorstep.

The urban centres of southeast Italy whose status as Greek poleis was fully accepted in the Greek world, ${ }^{129}$ fostered these mental links and maintained close contacts with the old world of Greece. Like several other Greek apoikíai, they manifested themselves in the major sanctuaries of Greece. ${ }^{130}$ Poleis of Magna Graecia erected treasuries ${ }^{131}$ and large sculptured groups serving as votive offerings. Taras, for instance, proclaimed its victories over non-Greek tribes in the sanctuary of Delphi. ${ }^{132}$ The disproportionate quantity of winners of the Olympic Games stemming from southern Italy indicates that athletic excellence could be another way for the apoikiai of this region to manifest themselves in the forums of the Greek world. The victory crowns of their athletes stressed the links of the south-Italian poleis with the motherland, underlined their Greek identity and enhanced the status of these towns.

The four apoikíai of Sybaris, Siris, Metapontion and Taras were, moreover, among the many states of Megalè Hellas (Latin: Magna Graecia). ${ }^{133}$ The contacts between the numerous new poleis of southern Italy must have been intensive. The artefactual evidence suggests that contacts were particularly intensive between these four urban settlements on the Gulf of Taranto: in their material culture (e.g. ceramics, metalwork) they had many features in common.

Relations with the supernatural must also be viewed as contacts with another world. The 'horizontal' distance towards other humans and the 'vertical' distance towards the gods as seen in the present-day western world are often not perceived as such in other societies. ${ }^{134}$ In Homer's Odyssea, for instance, the world beyond Ithaca (e.g. Italy) is as much an Otherworld as the realm of Hades or the Olympus. In the Greek, Roman, Celtic and Germanic beliefs, moreover, gods and spirits may inhabit rivers, springs, wells, woods and marshes. Many elements of the landscape are seen as the home of spiritual powers that inanimate the various parts of the landscape and load them with significances. Very similar ideas on the supernatural were held in pre-Roman southern Italy. Here caves, springs and wells can be shown to have been the place to consult or placate spirits and gods (see chapter 4, sections 2 and 3).

There are good reasons to believe that entirely new cult places came into being in southeast Italy in the Archaic-Classical period. It is, for instance, unlikely that each temple or temenos of the cluster of urban sanctuaries that came into being in the very heart of Metapontion, actually had a Bronze Age or Iron Age origins. The same may hold good for urban sanctuaries of Sybaris, Siris and Taranto. Just

\footnotetext{
28 Lomas 1993.

129 This seems to emerge from the fact that Greek colonies of southern Italy and Sicily participated in the Olympic games and had treasuries at Delphi and Olympia.

130 Philipp 1992; Rougemont 1992.

131 Mertens-Horn 1990.
}

\footnotetext{
132 Nenci 1979; Jaquemin 1992, 197-198.

133 The basically Latin tern Magna Graecia or its Italian equivalent Magna Grecia is currently used instead of the Greek term Megalè Hellas.

134 Helms 1992.
} 

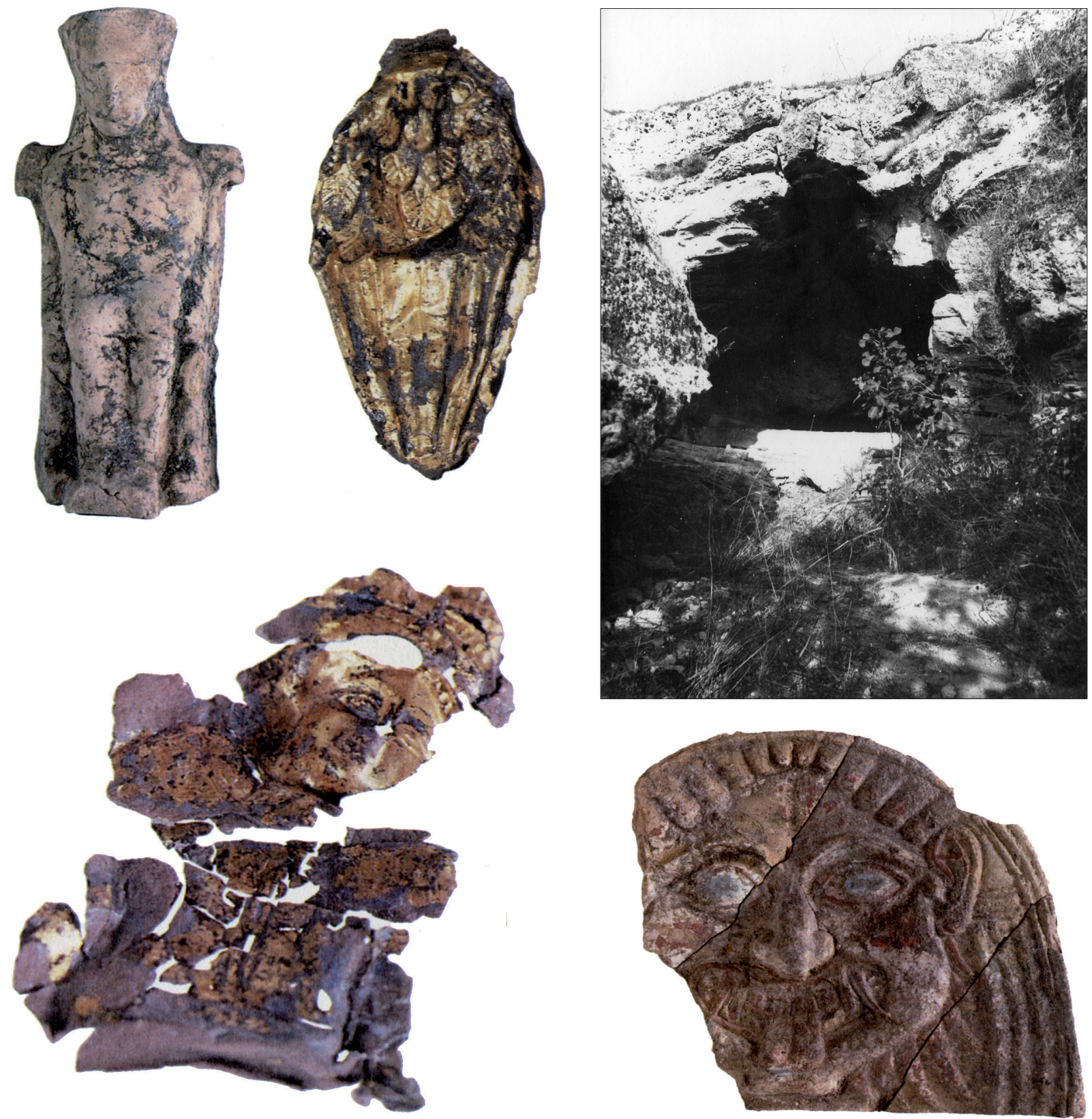

Fig. 5.37. Oria (south Apulia): cave (photo 1911; archive ACVU) and votive offerings (statuette, gilded bronzes, antefix) from the Monte Papalucio sanctuary (photos courtesy Lecce University); late 6th and 5th centuries BC.

as the foundation story and the oikist were invented history, the urban sanctuaries of Magna Graecia were largely if not exclusively the physical expressions of invented or newly created religion. Since they were the centres of rituals shared by the whole local community, they had at least partly the same function as the origin myths of the settlement: their existence helped to effect cohesion in the heterogeneous population that lived on the spot. They contributed to the forging of a new identity that was shared by all the inhabitants. Together with, for instance, the new orthogonal layout these new cult places were the embodiment of a new social identity of the inhabitants: they were now politai of the emerging poleis. With their sometimes impressive architecture, moreover, these temples underlined the wealth, pride and status of the new polis. They gave, moreover, each of the urban settlements the gods and rites shared by all its inhabitants. 
Some gods were probably new to southern Italy, but familiar to the Greek immigrants. Among these were Zeus Agoraios and Zeus Aglaios in Metapontion who migrated with Greek migrants. ${ }^{135}$ Other deities are much more difficult to qualify. The immensely popular goddesses Demeter and Persephone, for instance, worshipped in dozens of sanctuaries (both rural and urban) of southern Italy have patently Greek names. In several cases - both in rural sanctuaries in the territories of the Greek settlements and in the extramural sanctuaries of non-Greek districts - they may well be Greek guises of originally non-Greek vegetation goddesses. Names of Italic gods or spirits are hardly known for the period under discussion. ${ }^{136}$

These poleis with their large stretches of arable land are likely to have produced considerable surplusses. These could be traded and were, in fact, probably the main source of their very substantial wealth. This happened by means of exchange with the inland populations. Contacts between the urban centres on the coast and tribal groups in inland districts of southeast Italy are suggested by the presence of Aegean-Greek and colonial-Greek ceramics, bronzes and coins found in these native districts. ${ }^{137}$ Most of these - panoplies among them - ended up in burials of indigenous chieftains and their followers (see chapter 5.4). Sanctuaries in non-Greek areas also got their share of Greek or colonial-Greek objects. The archaic-classical votive deposits of the tribal sanctuary of Oria on the Salento isthmus contained, among other items, Attic black and red-figured pottery, silver coins from Metapontion, Sybaris, Kaulonia and Kroton, ceramics from Taras and Metapontion and probably Tarantine jewellery (fig. 5.37). ${ }^{138}$ Judging by the sheer quantity of Greek objects found in non-Greek contexts there must have been a rather intensive exchange between the tribal polities and the poleis of southeast Italy.

It should be noted that the four Greek towns of southeast Italy were not the only partners with whom the tribal polities outside the coastal area on the Gulf of Taranto exchanged goods. They also maintained contacts with other, very similar and equally new states that exerted their influence on the area under discussion. On the eastern shores of the southern Adriatic, close to the Strait of Otranto, more poleis arose. Here, Epidamos, Apollonia, Buthroton and Kerkyra were the new urban centres. They were separated by only 70 to $100 \mathrm{~km}$ of sea from the Salento peninsula. These poleis of Illyria were closely linked to the south-Italian trade networks during the 6 th and part of the 5 th centuries BC. The influence from artisans from these trans-Adriatic areas on the architecture of the tribal centres of Cavallino and Ugento (both in the Salento peninsula), shows that this trans-Adriatic connection should not be neglected (see chapter 5.3). Since Greek shipping penetrated more and more into the Adriatic during the 6th century BC, contacts with the crews of Greek ships that were intent on temporary shelter, food, fresh water, booty and barter must have occurred rather frequently. ${ }^{139}$ In the 5th century BC Attic workshops even produced redfigured wares with indigenous shapes which were characteristic of the Bari district and the Canosa area. ${ }^{140}$

135 De Siena 1998, 151; De Juliis 2001, 169-170.

136 The names of these spirits appear in Hellenistic and early Roman inscriptions and graffiti, i.e. from about the later 4th to within the 1st century BC.

137 The term colonial-Greek pottery is frequently used to refer to the ceramics with basically Greek technical, morphological and decorative features produced in the apoikíai.

138 D’Andria et al. 1990, 254-264 (ceramics) and 274-281 (jewellery).

139 On the strength of the finds of imported ceramics the contacts between native groups and Greeks were basically confined to Salento and the coastal area of Basili- cata during the 8 th and 7 th centuries. The presence of late-Corinthian pottery in the district around Bari suggests that this area became involved in Greek trade networks by about 580/570 BC. By about 530/520 Greek ships seem to have reached the Caput Adriae (emporia of Spina and Adria). For reasons unknown north-Apulian coastal settlements (Barletta, Salapia, Sipontum) display no signs of having been ports of call for Greek shipping in the Adriati, although these same coasts were involved in overseas trade networks during the Bronze Age (Mycenean wares from BarlettaMadonna del Petto, Coppa Nevigata, Molinella etc.). 
Exchanges were also made between various indigenous groups. In chapter 4 we have seen the dominant role exerted in this field by the north-Apulian settlement of Canosa and its almost princely chieftains in which the Adriatic networks were crucial. This settlement continued to play this same role during much of the 6th century BC. Canosan late 7th-century and 6th-century wares are found in large parts of southern Italy and in the northern Adriatic. Being some $150 \mathrm{~km}$ away from the breathtaking changes in the coastal area on the Gulf of Taranto the settlement continued to live in its Iron Age ways. Signs of change can be observed here only in the last third of the 6th century when Greek trade networks extended over the central and northern Adriatic and the emporia (trade stations) of Spina and Adria came into being near the mouths of the river Po. ${ }^{141}$

In the 6th century $\mathrm{BC}$ the traces of interregional exchange between non-Greek groups are plentiful. In addition to the widely distributed Canosan ceramics mentioned above, there is Campanian bucchero at Chiaromonte (western Basilicata), Arpi and San Severo (both in northern Apulia). ${ }^{142}$ The 6th century ceramics made in the north-Apulian plain reached Campanian sites in the Naples area such as Cancello, Nola and San Valentino Torio. ${ }^{143}$ Matt-painted ceramics from the Bari area are found at sites in the Bradano district, northeast of Metapontion. ${ }^{144}$ The mid 5th century BC princely burials of Pisciolo in northeastern Basilicata containing i.a. Etruscan bronzes and matt-painted wares and gold from northern-Apulia, testify to the intensity and continuity of such inter-tribal exchanges. ${ }^{145}$

It should be noted, however, that the examples for exchange between tribal groups cited above, come from the south-Italian districts that were relatively far from the new and rapidly growing urban centres of the 6th and 5th centuries BC such as Epidamnos, Kerkyra, Taras, Metapontion, Sybaris. The non-Greek districts that were closer to these poleis show hardly any signs of exchange with other indigenous districts. Much of this may be due to biases in the data set. ${ }^{146}$ The graves and sacred places of the tribal group near Metapontion, for instance, contain - in addition to locally produced items almost exclusively objects made at Metapontion or ceramics of Aegean origin (Corinthian, Attic) that can be surmised to have arrived at the inland settlement by way of Metapontion. ${ }^{147}$ It seems, therefore, that in economic respect inland tribes connected themselves more and more to the nearest Greek town during the 6th and 5th centuries BC. A probably substantial part of their surplus production was brought to the market in this same town. Products from tribal polities were either consumed there or entered the larger Mediterranean trade networks in order to be consumed at an overseas destination.

The surpluses generated in the territories of the urban centres themselves could, of course, also be traded by ship. That the articles produced by farming activities were important to the urban centres

140 Jentoft-Nilsen 1990; Robinson 1990.

141 Yntema 1979.

142 For Campanian bucchero from Chiaromonte and Arpi, see Tagliente 1987; for Campanian buchero from San Severo, see, for instance De Juliis 1977, pls. XCIV.B and XCV.A.

143 Yntema 1990.

144 See Bari matt-painted from the Bradano sites of Timmari, Gravina and Monte Sannace (Yntema 1990, 205 and 216)

145 For the royal burials of Pisciolo, see Adamesteanu 1974.

146 The clearest evidence on this subject consists of ceramics. Since - in the present state of research - no differences can be observed between the new Greek- style ceramics of the various tribal groups close to the poleis, there are hardly any means to trace inter-tribal exchange.

147 Salento is an exception to this rule during the 6th, 5th and early 4th century BC. Whilst Tarantine ceramics dominate in the area close to the Taras territory (e.g. at Oria), Metapontine ceramics are not uncommon in the Brindisi district and southern Salento in the late 5th and early 4th century (till c. 370 BC). There is, moreover, good reason to assume that the Salento groups had direct contacts with Aegean Greeks (Salento coastal settlements serving as port of call and place of exchange for Greek ships coming from Athens, Corinth etc.). 
on the Gulf of Taranto is shown by their silver coins: Metapontion choose the ears of corn as its symbol, whilst Sybaris' coins displayed a bull. There is, however, only a limited set of evidence pointing at overseas transport of agricultural products from southeast Italy in the 6th and 5th centuries BC. The best indicators of these activities are the so-called Corinthian B amphorae, produced from the 6th century onward (fig. 5.33). They were probably mainly used for the transport of wine. Analyses of various types indicate that these amphorae are likely to have been made (and filled) at Sybaris and possibly in other urban centres around the Ionian Sea and Gulf of Taranto. ${ }^{148}$

The very casual statements made above regarding agriculture and stock raising are mainly educated guesses based on artefactual evidence such as farmsteads, coins and ceramics. It has been said above that the bio-archaeology is still in its infancy in southeast Italy and that, moreover, the soils do not really favour the preservation of plant remains. The scant bio-archaeological data makes it hard to construct an image of the changing environment of southeast Italy.

Indeed, there are hardly any pollen cores for the period under discussion. The best pollen evidence published hitherto regards the rural site of Pizzica Pantanello, basically a group of dispersed farmsteads with a common burial ground and a rural sanctuary. ${ }^{149}$ The pollen from late 7 th to 6th century BC (the sample is not ideal) suggest a fairly open landscape (hardly any pollen of oak and fir) with grazing areas, corn fields and some olive groves. The latter were probably fairly rare till about the late 6th century BC, i.e. after the creation of a regular land division system. ${ }^{150}$

Bone samples dating to Archaic-Classical times are only slightly more numerous than legible pollen cores. Our main concern here is with the larger species of animal husbandry: cattle (Bos taurus), sheep/ goat (Ovis/Capra) and pig (Sus domesticus), although hunting was also popular (often between 5\% and $10 \%$ of red deer (Cervus elaphus), especially at sites of tribal groups). The contribution of hunting to the various local diets could even be larger than the diagrams suggest, since the bones of the wild boar (sus scrofa) can often not be distinguished from that of domesticated pigs. However, it should be noted that the number of samples concerning the period under discussion is still very limited, especially for the urban centres. Any general line or conclusion concerning bone samples of the archaic-Classical period should, therefore, be treated with great circumspection.

Samples have been published from both the polis of Metapontion and from various sites which were inhabited by tribal groups (Valesio). The first results of the samples analyzed hitherto are that cattle seems to be relatively rare (some $5 \%$ to $10 \%$ ) in the area that - by the 6th century $\mathrm{BC}$ - was probably under control of the urban centre as Greek. These draught-animals were used for ploughing and transport. The bone spectre in the territory of the town is dominated by sheep/goat (approximately $60 \%$ ) with pigs having the second place (c. 20\%). In the areas of the non-Greek tribes, sheep/goats are also the dominant species (c. 40\%-50\%) with again the cattle in the second place (c.25\%-30\%) The percentage of cattle in the bone samples is much higher here than in the area surrounding Metapontion (between 25\% and 35\%). Since the standard view on southern Italy has pictured the early Greeks as farmers and the contemporary 'natives' mainly as herdsmen, it is at least surprising to see that the few bone samples published hitherto seem to belie this standard image. But they tie in nicely with the results of the pollen cores from the Metapontion area that suggest the presence of large grazing areas in the earlier 6th century BC, i.e. in a time that preceded that creation of a regularly laid out countryside.

148 Sourisseau 2011

149 Carter 1998a.

150 Carter 1987, 191; the moment, therefore, is not really surprising since it takes some 20 to 25 years before an olive tree bears fruit. The trees may well have been planted shortly after the regular land division was made. 


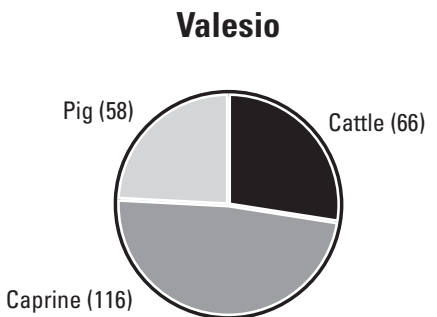

a

Fig. 5.38. Bone samples from southeast Italy (late 6th-early 5th century BC): Valesio (a) and Cavallino di Lecce (b), south Apulia.

\subsection{A N CIEN T W R I T E N S O UR C E A N D IN T E L L E C T UA L A C H I E V E M E N T S}

In the preceding chapter we have explained that the image offered by the ancient written sources for the 8th and 7th centuries BC is very hazy and displays signs of being a mix of real events and invented history. By the 6th century BC writing became widely diffused in Greece. Various kinds of documents were composed in writing. Therefore, the ancient written information on what happened in southeast Italy should be discussed here. The historical narratives based on these writings, have been presented by i.a. Ciaceri, Dunbabin and Pugliese Carratelli. ${ }^{151}$

The 6th and 5th centuries BC in southern Italy are often seen by modern scholars as periods of conflicts between two strongly opposed groups: immigrant Greeks against autochthonous natives. The antithesis between both groups is strongly suggested by the ancient written sources that were predominantly composed by Greek authors. Part of this antithetic view was discursively constructed and belongs to the world of rhetorics. It has been convincingly demonstrated that the Greek-Barbarian antithesis plays a significant role in many Greek writings, and especially so from the 5th century BC onward. ${ }^{152}$ Moreover, conflicts - however incidental they are - are likely to become part of the collective memory and, therefore, have a good chance of entering into the historical record. There is, however, no reason to deny that from time to time great conflicts arose between the inhabitants of the poleis and autochthonous groups of southern Italy. Especially from the later 6th century BC onward both groups must have had quite opposed interests. The new polities of southeast Italy that labeled themselves as patently Greek poleis, carved their territories out of what autochthonous population may have considered to be 'their' lands. This resulted in the formulation of identities in which the 'we' or 'self' were clearly opposed to the 'others'.

The conflicts in southeast Italy, were not exclusively fought between Greeks and 'natives'. There is quite a lot of evidence pointing at great competition and bitter conflicts between the various Greek states of southern Italy (see below). There is, moreover, no reason to believe that it was exclusively peace and quiet between the various indigenous tribes that inhabited the areas under discussion. The political landscape with all its inter-polity conflicts was doubtlessly much more variegated and complex than the Greek-native bipolarity constructed by the ancient Greek authors suggests.

151 See Ciaceri 1924-1932, Dunbabin 1948, Pugliese

152 Hartog 1980; Hall 1989. 


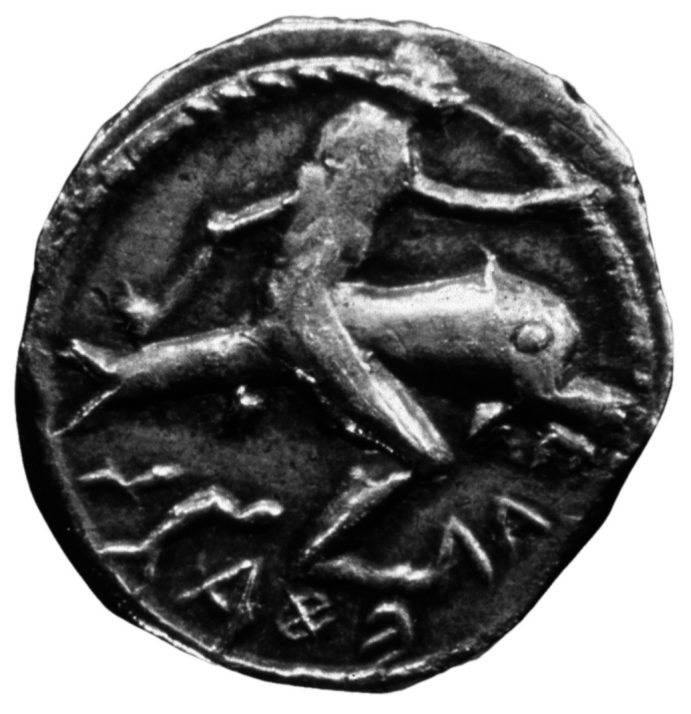

Fig. 5.39. Indigenous emission inspired by early 5th century Tarentine coins bearing the name of WALETAS. Courtesy Cabinet des Medailles. Paris.

As we have seen in the preceding pararaph 5.6, the origo myths of the various Greek polities were composed in the 6th or 5th century BC and projected a basically 6th or 5th century situation back into the distant past. They indicate that these towns definitely claimed a 'Hellenic' identity at the time of writing. This identity was stressed by a foundation story that linked to town to a so-called mother-city (metropolis) in the presumed Greek core area. The oikist featuring in the same story became the badly needed local hero around whom the polis's hero cult arose. He was the local focus of the local community.

The tribal groups of southern Italy, however, had their own stories about their roots. Most of what survives of these in Greek and Roman written sources does certainly not stress their autochthonous, Italic character in clear opposition to the Greek immigrants, as perhaps would be expected. The 'tribal' origo myths recorded by Greek authors suggest that the indigenous groups were basically 'Hellenes'. A good and relatively early example is a story told by Herodotus about the origins of the Messapians in the very south of Apulia: they were basically Cretans who on their return from Sicily to Crete were shipwrecked on the south-Italian coast (box 5.1).

\section{Box 5.1}

Herodotus VII. 170:

"Since they had lost their ships and saw no possibilities of returning to Crete, they founded the town of Hyriè (= Oria, Salento isthmus) and settled the surrounding district. They changed greatly, because from Cretans they became Messapian lapygians and from island-dwellers they became continentals. Starting from Hyriè they founded the other towns..." (translation: DY). ${ }^{153}$

Other non-Greek groups of southeast Italy were said to have comparable pedigrees. The Oinotrioi who lived in the region of Basilicata before the coming of the Lucanians, were sometimes believed to have come from Arcadia. ${ }^{154}$ Indigenous settlements were said to have been founded by heroes of the

153 Iapigia is probably a general denomination of southeast Italy and Iapygians is probably a collective noun for various tribal groups (cf. Nenci 1978). The Messpians is the name the Greeks applied to the southernmost group(s) of the Iapygians in the present-day Salento peninsula (see chapter II). Hyriè is commonly equated with the present-day settlement of Oria (the Roman municipium of Uria Calabra, ORRA on coins of the 2nd century BC).

154 Dionysius Halicarnassus I. 11. 
Trojan war. These stories tell us that the Apulian towns of Brindisi, Canosa and Arpi (Greek: Brentesion, Kanousion and Argyrippa), for instance, owed their existence to the great king Diomedes of Argos. The origo myths of the tribal populations, therefore, suggested that they were basically Greeks who had settled in southeast Italy long before the Iron Age 'colonial' Greeks arrived.

These stories suggesting that the indigenous populations of Italy were basically descendants of Bronze Age Greek immigrants, were told by Greek writers. It has repeatedly been stated that these ideas aired by Greek authors tell us more about Greek views on indigenous origins than about the views of indigenous populations on their own roots. This is a very unlikely option for southern Italy. The tribal origo myths pictured Messapians and Oinotrians as arch-Greeks and gave the indigenous groups to which they referred precedence over the immigrant Greeks: they supplied the former with a far better claim on the heavily disputed soil. Research into Etruscan roots stories, moreover, has shown that the Etruscans were well aware of the fact that Greeks (from Hesiod onward) saw them as descendants of Odysseus and Circe. ${ }^{155}$ There are good reasons to believe that the same observation holds good for the non-Greek groups of southeast Italy. ${ }^{156}$ Not unlike the Etruscans, the indigenous populations of southeast Italy appropriated Greek myths and adapted them to their own purposes by presenting themselves as descendants of Greeks living in the heroic age.

Some of the Greek towns struck back by fabricating Bronze Age 'mythical' origins on top of their Iron Age ktisis stories. ${ }^{157}$ Metapontion was allegedly founded by Nestor's Pylians and Siris was portrayed as a settlement of Trojan refugees that at some point of its history had evidently been taken over by the regional tribe of the Chaones. The competition for land in the 6th, 5th and 4th centuries BC is reflected in a competition of myths: the settlement or group with a Greek ancestry and the longest local pedigree evidently believed to have the best claim on the soil. The only groups that seem to have stressed an Italic origin were those of the Lucanians: they probably believed themselves to be of Sabellic stock. ${ }^{158}$

The general lines of the political history of southeast Italy as told by the ancient written sources and interpreted by modern historians have been sketched many times and with only limited variations. Here only a short summary will be given in order to see what ancient written sources tell us about the districts and periods under discussion.

Usually, there was a strong competition between the poleis. Their differences and rivalries were, i.a., expressed the lavishness of their sacred and secular architecture (temples, fortifications) and in the foundation stories that gave them different origins (see paragraph 5.6). The earliest conflict mentioned in the ancient written sources is that between Siris and two neigbouring poleis. In about 540/530 BC the polis of Siris with its 'Ionian' origo myth was destroyed by Sybaris and Metapontion, both towns with allegedly Achaean roots. ${ }^{159}$ A few decades later 'Achaean' Sybaris fell victim to its southern

155 Dench 1995, 39-41.

156 Among the limited quantity of ceramics with figurative decoration produced in the indigenous Salento district is a trozzella (funerary pots with high handles and wheels on top of the handles with representations of the Theban Cycle from the site of Monte Salete (see Johansen 1972; Santoro 1976; Tiverios 1980) and a hydria from the Monte Papalucio sanctuary of Oria with a scene showing probably Odysseus and Circe (fig. 5.31b). Both pots date to the 5th century BC.

157 For both the Bronze Age and Iron Age foundation stories of Greek settlements in southern Italy, see Bérard 1957; for recent interpretations of these stories, see
Malkin 1998.

158 For a Sabellic origin of the Lucanians, see, for instance, Strabo, Geography, VI.1.3, Pliny, Natural History, III.71, Justinus, Epitome, XII.2.12.

159 The archaeological evidence suggests that there was continuity of occupation at Siris. Probably the settlement lost its status as independent polis. The dating of the 'destruction' can be put somewhere between 550 and 525, because the people of Siris managed to build (or lay the foundations of) a faily substantial temple. The developments at highly prospering Metapontion show that this could hardly have happened before $560 / 540$ BC. 
neighbour, the 'Achaean' polis of Kroton. This happened in 510 BC. For approximately the same time conflicts between Greek towns and indigenous groups are mentioned. The polis of Taras dedicated two large groups of sculptures in the pan-Hellenic sanctuary of Delphi in order to celebrate its victories over the Messapians (southern Apulia) and Peucetians (central Apulia). ${ }^{160}$

According to the ancient written sources it was in the course of the 5th century BC that nonGreek groups began to rout the Greeks of southern Italy. In about 470 BC the Messapians inflicted a disastrous defeat on the Tarantines and their allies, ${ }^{161}$ whilst the Lucanians posed an increasingly serious threat to the Greek societies on the coast from the moment Thourioi was founded at the site of Sybaris (444 BC). In 435 Siris was revived as Herakleia (in Lucania), being now a colony of Taras. Towards the end of the 5th century the Lucanian pressure on the Greek coastal settlements culminated in wide-spread Lucanian aggression towards Greeks towns. According to the ancient written sources the first major attack was launched on Thourioi in c. 433 BC, whilst the Tyrrhenian-Greek towns of Poseidonia (Paestum), Terina and Laos were conquered in respectively 410, 395 and 390 BC. ${ }^{162}$

The ancient written sources tell us little about the social structure of the societies of southeast Italy. In a casual way we learn from them that urban centres such as Taras and Metapontion had their aristocracies, whilst persons with a special status could also be found in the areas that the Greeks perceived as barbarian territories. Among the large sculptural groups at Delphi dedicated as anathemata, for instance, the Greek author Pausanias records two Tarantine specimens celebrating victories over south-Italian indigenous groups. A native 'king' (basileus) called Opis was part of the one of these groups. ${ }^{163}$ Thucydides moreover mentions a Messapian 'dynastes' named Artas who supplied the Athenians with 120 spear throwers (akontistai) for their disastrous campaign in Sicily in the year 413 BC. ${ }^{164}$

A first striking element in the surviving passages of Greek authors regarding the archaic-classical period is the stress laid on the creation of identities (e.g. origo myths, stressing of links with Aegean Greece). This type of behaviour may be expected of the new polities that presented themselves as Greek poleis. They competed intensely with each other and were equally involved in struggles with neighbouring tribal groups. Since competition is a form of discourse, it is not surprising that the tribal groups made use of comparable rhetorics. As we have seen above, they presented themselves as descendants of Greeks of the heroic age by suggesting a Minoan (Messapians) or Arcadian (Oinotrians) ancestry. Non-Greek settlements such as Brindisi, Canosa and Arpi heralded their distinguished pedigree: they claimed to have been founded by Greek heroes of the Trojan war. In this way they presented themselves as Greeks having links with the heroic age (and certainly not as barbaroi) and indicated that they had arrived in Italy several centuries before the new groups of Greeks founded their poleis.

A second striking point is the repeated suggestion emerging from passages of the ancient authors that the non-Greek peoples began to pose a severe threat to the Greek communities on the coast during the 5th century BC. The terrible defeat suffered by the Tarantines and their allies in 473 at the hands of the Messapians and the seemingly constant harassing of Greek colonies in Basilicata, northern Calabria and Campania by the Lucanians heralds the birth of new and higher level of political and military organization in the indigenous groups of southern Italy. From the 5th century onward someone in those tribal communities was able to muster quite large quantities of well-trained and well-armed warriors and had enough fighting power and military tactics at his disposal to rout the cavalry and break the hoplite ranks of the polis. This probably means that in the 5 th century BC a more hierarchical tribal system came into being. It was characterized by a new form of leadership that went

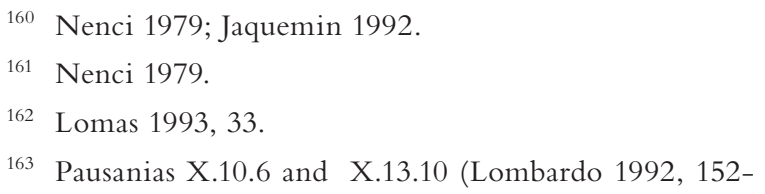

3, texts 279 and 280); for comments see Nenci 1979 , 27-30.

164 Thucydides VII. 33 (Lombardo 1992, 13, text 19). 
far beyond the local, and possibly even beyond the cantonal level of the societies concerned. These new, possibly regional or supra-regional leaders of the indigenous areas were probably the dynastai and the basileis mentioned by Greek written sources. ${ }^{165}$ The genesis of the Lucanians will be discussed in more detail in the following chapter.

The drastic innovations of the 6th and 5th centuries BC can not only be observed in, for instance, the social sphere, the regional economy and the material culture of southeast Italy. Italiote Greeks were important initiators and participants in the intellectual revolution that took place in the Greek world. Though Megalè Hellas produced only a few lyric poets of great repute (e.g. Ibycus from Rhegion), several Italiote Greeks played a significant role in the fields of philosophy and sciences. Elea (on the fringes of ancient Lucania) and Taras were famous centres of philosophical thought in the period under discussion. The founding fathers of these two rather different schools of thought were Parmenides and Pythagoras. ${ }^{166}$ Pythagorism, moreover, was not just a school of philosophical thought: it was basically a way of life and pervaded even the local politics in Greek towns on the Gulf of Taranto. Pythagorism, moreover, was also linked with science and contributed, for instance, in a significant way to the development of Greek mathematics. ${ }^{167}$

\subsection{S U M M A R Y}

The Archaic-Classical period in southeast Italy is characterized by a series of very drastic changes. They started at a relatively slow pace between $620 / 600$ and 570/550 BC, accelerated enormously in the next 80 to 100 years, and slowed down after 470/450 BC. In a relatively short, but explosive period a completely new southeast Italy was created. It differed in many ways from the Iron Age world of the 8 th and 7 th centuries BC.

The most baffling innovation was the rather sudden birth of four completely new, highly complex polities on the coast. They labeled themselves as apoikíai, i.e., as Greek poleis with a migrant population in an originally non-Greek area. They each consisted - just as the Aegean polis - of both a town and a countryside. Part of their inhabitants must indeed have been migrants coming from Aegean areas, but many persons with Italic roots are likely to have belonged to the inhabitants of these urban centres. Just as in the Aegean areas these people made up the citizen body of the polis. The political constitutions of these new poleis shifted regularly from aristocratic to oligarchic or democratic and back. They differed vastly from the Iron Age polities of southern Italy: while the latter had many tribal characteristics, the four new polities were states in the technical sense of the word. Because their inhabitants were all migrants coming from a variety of geographical backgrounds, they had no local identity and no shared past.

For these new states with their heavily mixed populations internal coherence had to be created. Identities shared by all inhabitants had to be forged in order to achieve a sense of community and to survive in the rapidly changing world of southeast Italy. This happened, for instance, by creating origo myths (the foundation story), a local hero and a hero cult (oikist) and a representative local architecture (temples, public buildings, town walls). Cults connected with these features provided a strong focus for local identity. What also must have helped to achieve coherence was that these were entirely new territories that - as neighbouring indigenous groups may have felt - were carved out of existing indigenous territories. Both the foundation stories (which depict basically 6th- and 5th-century situa-

165 Strabo, Geography VI. 254.

167 Szabó 1988.

166 Lesl 1988. 
tions) and 'historical' accounts concerning the events of the 6th and 5th centuries tell us about severe unpleasantness arising from territorial conflicts. Of course, there is no better means to create coherence and unity than a good process of Othering.

In addition to their local identities (e.g. those of Metapontines, Tarentines) the inhabitants of these new urban centres - whatever their real origins - also stressed their Hellenic identity. They did so by linking themselves and their settlements to the venerated past of Aegean Greece. The foundation story linked them to a mother city in the Old world of Greece. Both myth (e.g. the nostoi; Herakles in Italy) and ritual (foundation oracle, Pan-Hellenic games, cults shared with the metropolis) provided more connections between the new Greek world of southern Italy and the traditional Greek core area.

This new world of southern Italy manifested itself not just mentally (see paragraphs above), but also physically. These physical aspects were expressed in the enormous changes in the coastal landscape on the Gulf of Taranto. The first urban landscapes ('townscapes') of southeast Italy came into being. Settlements were set up on the basis of orthogonal town plans. In the surrounding territories there was, moreover, considerable reclamation of wild nature. The wilds here were turned into strictly organized and relatively densely inhabited countrysides with cornfields, olive groves, vineyards and grazing areas. In both urban and rural landscapes a new type of sacred places came into being: the temenos with or without religious buildings where food and artifacts were deposited as gifts to the local spirits.

Similar changes affected adjoining areas inhabited by tribal groups. Here these changes took place in an existing socio-political landscape. They were, therefore, less drastic. While the layout of the new tribal settlements often continued to be rooted in Iron Age situations (except at Serra di Vaglio, it seems), the architectural outfit was entirely new: clusters of houses replaced clusters of huts, whilst a limited number of these settlements was surrounded by defences. Sacred places made their appearance in the archaeological record. Some of these Italic sanctuaries were in the hearts of the settlements of the tribal groups (Cavallino, Ugento), but most of these were outside the settlement areas. They were often located near wells and in caves, i.e. in places where there seemed to be an entrance into the earth. They are recognizable to the archaeologist only because of the presence of votive offerings deposited after the Greek fashion. In fact these Italic sacred places may have much earlier origins and started their life before the time when the custom of depositing artifacts for supernatural powers had been adopted by the non-Greek societies of southeast Italy.

The indigenous tribes did not just reorganize their physical landscapes. Their mental world also underwent significant changes, as is clear from the new guise of their religious practices. In addition, they also seem to have reshaped their past. Their origo myths (written down by Greek authors) suggest that they presented themselves as a kind of arch-Greeks: the indigenous groups believed to descend from Greeks of the heroic period and therefore had arrived in Italy long before the first Greek migrants came to that region. Especially in times when there was a fierce competition for land (e.g. 6th and 5th centuries BC), such myths were highly meaningful to the present. The indigenous groups boasted of being Greek and of 'being there first'; they professed to be the descendants of the great king Minos (e.g. the Messapians), migrated Arcadians (the Oinotrians) or the sons of a Greek hero of the Trojan War such as Diomedes of Argos (the inhabitants of Brindisi, Canosa and Arpi).

The rapid developments that affected both Greek polities on the coast and tribal societies of Apulia and Basilicata, resulted in relatively populous societies that were much more complex than the preceding groups of the 8th- and 7th-century Iron Age. Although the latter were far from being egalitarian, social stratification increased substantially in the new societies of the 6th and 5th centuries BC. It resulted in the birth of tribal elites and urban aristocracies. Both must have had much in common. If indeed the assemblages of artifacts in the burials reflect the world of the living, banqueting and displaying paideia were part and parcel of elite behaviour in both Greek towns and indigenous polities 
of southeast Italy. Both participated in an elite ideology shared by all south-Italians alike. The story that the philosopher Pythagoras who lived in southern Italy in the period under discussion, had native followers may well be apocryphal. ${ }^{168}$ The bare existence of the story, however, shows that Greeks sometimes viewed individuals of their indigenous neighbour populations as 'cultured' people.

Increased complexity could also be observed from the 6th century onward in the various sectors of craft. In the 6th and 5th century settlements all over southeast Italy there were much more craftsmen and much more different types of craftsmen that in any preceding period. Pottery production became highly standardized with various specialists working together in a team. A similar model can be surmised for iron and bronze production and for the building activities in which carpenters, stonemasons and tile makers cooperated. New production methods, new specialist forces and a new scale of artisan production were introduced. The variability of shapes and types of the products themselves, moreover, increased enormously.

There are many more signs of increased complexity. The issuing of silver coins carrying the symbol of the polity was not just a manifestation of local pride. The appearance of coins around $530 \mathrm{BC}$ is equally a sign that such an officially guaranteed standard quantity of silver was needed in order to play a role in larger transactions or to establish and maintain relations between man and man and humans and gods. ${ }^{169}$ The emission of coins, moreover, is not confined to the new poleis, but is equally reported for tribal units in present-day Calabria and Basilicata in the late 6th century. ${ }^{170}$ The silver coins bearing the name WALETAS from the Brindisi district dating to the first half of the 5th century (fig. 5.39) are believed to be emissions of a native chief, tribe or settlement.

The Greeks of Italy wrote since the 8 th century BC. ${ }^{171}$ There are only a few examples of 7 th-century writing from the area under discussion. They suggest that the use of written texts was fairly limited in that period. It was not until the birth of more complex societies of the 6th century BC that the art of writing truly diffused. ${ }^{172}$ The poleis were, or soon became relatively literate societies. Writing, moreover, was not limited to the Greek towns on the coast: from about the late 6th century BC writing also diffused over the tribal areas of southern Italy. It was however, not before the 4th century BC that inscriptions in Messapic and Oscan become fairly numerous.

The rapid changes that affected southeast Italy from early-Archaic times onwards were stimulated by increasingly regular and intensive contacts. These occurred within southern Italy on the one hand: between Greeks and Greeks, between Greeks and Italic tribal groups and between non-Greeks and other indigenous polities. Since the new Greek polities of southern Italy maintained and reinforced the mental links and physical contacts with the old world of Aegean Greece and since the states of Aegean Greece were warmly interested in trade and exchange with Greek and Italic groups in Italy, the contacts between both these areas reached a higher level of intensity than ever before. ${ }^{173}$ This all started in a period in which both areas went through an evolution that was unprecedented in both its scope and its speed. The changes in one of these large areas served as a catalytic agent in the other and vice versa.

What caused this sudden burst of innovation is uncertain. External causes, of course, are often used as a deus ex machina in order to explain sudden changes and rapid evolutions. As for southeast Italy, it

\footnotetext{
168 Iamblychus, Life of Pythagoras 34.241; on this subject, see Mele 1981.

169 Coins were often deposited in the sanctuaries of southeast Italy.

170 Parise 1972.

171 Pavese 1996.

172 Arena 1988.
}

173 It should, of course, be observed that Aegean Greece and southern Italy were not the only areas of the Mediterranean that changed enormously; more or less comparable changes took place in the northern Aegean, the Black Sea area, Cyrenaica, Etruria and Latium and southern France. 


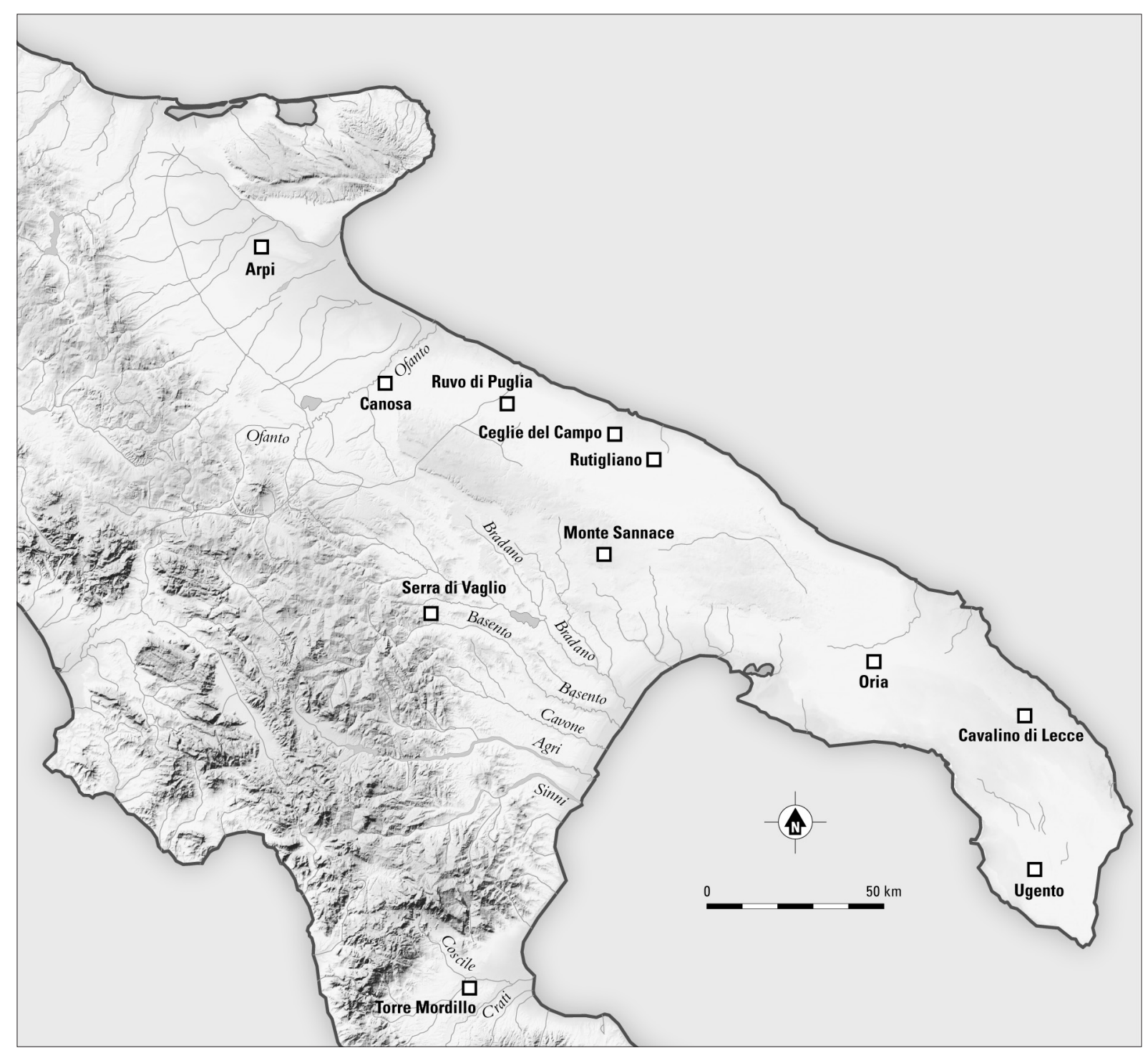

Fig. 5.40. Southeast Italy: tribal centres of regional importance, c. 550-450 BC.

is clear that there were external causes indeed. These, however, can certainly not be held responsible for every innovation that occurred in the areas under discussion. They are likely to have served as a strong catalytic agent. The key to the solution of this problem can probably be found in two important questions that should be addressed here. They concern two highly conspicuous new features that are characteristic of the 6th century BC in southeast Italy: the much larger population and the general opulence. In the 6th century BC southeast Italy was wealthier and more populous than ever before. These characteristics can be translated into two simple questions: Where did all those people come from? And what was the cause of their opulence?

It is easier to ask these questions than to answer them. As for the first question one may recur to the classic solution of mass migration from Greece to southern Italy. This means that the large migrations that were probably wrongly believed to have taken place in the later 8th and earlier 7th centuries (see preceding chapter 4), should be simply transferred to the later 7th and early 6th century BC. Though the phenomenon of mass migration in antiquity has always been a spiny subject, there may indeed be some truth in this option. But most probably Greek migration to southern Italy was more of a steady 
trickle than a sudden flood of migrants. By about the middle of the 7 th century BC southern Italy had become an alternative to hand to mouth existence in ancient Greece. The Greek poet Archilochos, writing about that time, had heard of the fat lands near (the river?) Siris and preferred them as a migration area to stony Thasos that was so much closer to his Paros home. ${ }^{174} \mathrm{~A}$ passage by the 5th-century author Antiochos of Syracuse suggests that larger groups (dozens or perhaps a one or two hundred) could also be on the move under particular circumstances. ${ }^{175}$ Moreover, it should be observed that persons with Italic roots had been part of the population of the coastal settlements since the first dwellings were built there. The poleis of Megalè Hellas, moreover, are likely to have been rather generous in granting citizenship. Therefore, indigenous groups contributed in a very substantial way to the populations of the new urban settlements on the coast.

These factors contributed to the rapidly growing population figures of the Greek towns, but do not explain the demographic growth in the districts inhabited by Italic tribes. ${ }^{176}$ Nor do they offer any explanation for the substantial rise in prosperity that affected all areas of southeast Italy, both the Greek urban centres and the non-Greek polities. Rise in population figures and rise in prosperity, however, have at least one cause in common: more food, i.e. a better and more varied supply of food that reduces mortality rates, while surplusses of foodstuff can be used in exchanges. This topic, however, has hitherto received little attention. One of the causes of population growth and prosperity that have been suggested is the introduction of new crops. ${ }^{177}$ This suggestion has not been confirmed by the archaeo-botanical samples collected in recent years. ${ }^{178}$ Other causes that have been suggested are technical improvements in agriculture and the introduction of rotation crops. ${ }^{179}$ More protein (meat) also helps in creating higher survival rates. But much more research is needed in order to see whether indeed important changes in agriculture and stock raising contributed in a significant way to the increasingly populous and increasingly prosperous southern Italy of the 6th and 5th centuries BC.

In the Archaic-Classical period many more people lived in southeast Italy than in the preceding Iron Age. Moreover, entirely new territories (the poleis) were created within the same geographical setting. The hierarchization of the settlement patterns resulting in the rise of major tribal centres such as Serra di Vaglio and Cavallino di Lecce, moreover, suggests that some reshuffling of the originally Iron Age territorial delimitations and changes in the pecking order of settlements took place in the tribal districts of southern Italy. The 6th century BC in southern Italy is characterized by the genesis of an entirely different social and political landscape. The population growth, the intensification of the use made of the soils and the changes in territorial delimitations resulted in competition for soil and in increasing social stratification. These factors are likely to have generated social stress.

The consequences of this revolution were dramatic. The increasingly territorial behaviour of the emerging Greek polities resulted in conflicts between the various Greeks polities themselves and between the Greek states and indigenous Italic groups. As we have seen above there must have been much more peaceful coexistence than the sources would have us to believe, but pitched battles also occurred. These were not just fought in skirmishes and border raids. In fact, major battles took place. In his account on the Messapian victory over the Tarantines in c. $470 \mathrm{BC}$, Herodotus grossly exag-

174 It is unclear whether Archilochos wrote about the settlement or the homonymous river in southern Italy.

175 Quoted in Strabo's Geography, VI.1.14. The story is about an unspecified group of people from Colophon on the coast of Asia Minor who migrated to SouthItalian Siris, because their hometown had been taken by king Gyges of Lydia.
176 Migration of individuals or family groups from the tribal districts to the 'Greek' urban centres of southern Italy is, of course, not indicative of substantial population increase in these tribal areas.

177 Mertens 1996, 246.

178 Lentjes 2013.

179 Carter 1987. 
gerates the numbers of victims on the Greek side. ${ }^{180}$ But his words ('the greatest slaughter of Hellenes till our days') make it patently clear that this was no small matter. We are not informed on the intertribal conflicts, because Greek authors were probably not interested in such regularly recurring events far beyond their world. But in more inland areas of southern Italy the drastic restyling of the sociopolitical landscape will certainly have triggered blows and fights.

In this increasingly populous, prosperous and competitive world of southeast Italy new and complex polities were born. Among these were the aristocracies and democracies of the poleis. But the traditional tribal structures of the indigenous groups underwent similar changes. The Iron Age warrior-chieftains evolved into tribal aristocrats functioning within tribal systems that were much more hierarchically structured than in the Iron Age. Local groups clustered into regional groups and these - perhaps under particular circumstances - could cluster into supra-regional groups.

This process can be observed all over southeast Italy. Oria on the Salento isthmus was a tribal centre of regional importance and had a sanctuary and an elite of comparable status. In most areas the supraregional level seems to be lacking. In the Salento peninsula Oria, Cavallino and Ugento were the regional centres: there was no settlement that ranked above these. Comparable situations can probably be found in central and northern Apulia: Monte Sannace, Rutigliano-Castiello, Ceglie del Campo/ Valenzano, Ruvo di Puglia, Canosa and Arpi were all substantial centres controling a district containing a series of smaller settlements during the 6th and 5th centuries BC (fig. 5.40).

The process of hierarchization was most pronounced in the mountainous areas of southeast Italy. Such larger, more hierarchically structured tribal units were perceived as a new phenomenon by both Greeks and non-Greeks. Hence they sometimes used a new term for something that for them represented an entirely new reality. Segmented groups which had been indicated as Opikoi, Chaones or Oinotrioi, for instance, now became the large and threatening tribe of the Lucanians. This development is illustrated by the rise of a large tribal centre of regional or even supra-regional importance in the late 6th century (e.g. Serra di Vaglio) and the appearance of a new regional or supra-regional elite in the late 6th century BC (the 'royal' burials of Baragiano, Serra di Vaglio-Braida and Pisciolo). The topic of the rise of the Lucanians, however, will be discussed in more detail in the introductory part of the following chapter

During the 6th century BC large parts of southeast Italy changed enormously. Whilst northern Apulia retained much of its Iron Age way of life, drastic innovations affected the districts on the southern Adriatic and the Gulf of Taranto. These changes are related to, but not dependant on what happened in Aegean Greece and other parts of the eastern Mediterranean, just as innovation in the latter areas was related to the changes in the western Mediterranean. The rapid changes in each of these two large macro-regions acted as a catalytic agent in the other. Southern Italy was not just receptive to Aegean forms, schemes and ideas, but had its own powerful dynamics. Magna Graecia contributed in a significant way to the intellectual achievements of the Greek world. But an important stimulus for change was the interaction between autochthonous Italic groups and migrants coming from various parts of Greece. The opposition between these was not as strong as the ancient written sources suggest. Both autochthonous populations and first, second and third generation migrants were involved, and both internal and external factors contributed to create societies that were vastly different from those of both Iron Age Greece and Iron Age Italy. In a relatively short span of time entirely new societies were born and many existing societies of southeast Italy changed their lifestyle, their material culture, their environment, their views and their past.

180 Herodotus VII. 170. 